\title{
The Improvement of Plants Through Bud Selection
}

\author{
BY \\ A. D. SHAMEL \\ Physiologist of the U.S. Department of Agriculture
}

HONOLULU, HAWAII 





\title{
EXPERIMENT STATION
}

OF THE

HAWAIIAN SUGAR PLANTERS' ASSOCIATION

\section{The Improvement of Plants Through Bud Selection}

BY

\author{
A. D. SHAMEL
}

Physiologist of the U.S. Department of Agriculture 


\section{$5 B 123$ \\ .55}

\section{LETTER OF TRANSMITTAL}

To the Experiment Station Committee of the

Hawaiian Sugar Planters' Association, Honolulu, T. H.

DEAR SiRS:-

I transmit herewith for publication a paper by Mr. A. D. Shamel, Physiologist of the U. S. Department of Agriculture, entitled "The Improvement of Plants Through Bud Selection." This paper was presented by Mr. Shamel at a meeting of the Social Science Association of Honolulu, March 7, 1921, and is published through the courtesy of that organization.

Respect fully,

H. P. Agee,

ain

Director.

Publizher

Јลี่ง 71922

$\therefore \vdots$ 


\section{PREFACE}

The present paper was prepared at the suggestion of $\mathrm{Mr}$. Alonzo Gartley for presentation to the members of the Social Science Association of Honolulu. After reading, the members of this Association kindly consented to the request of Mr. H. P. Agee that it be published by the Experiment Station of the Hawaiian Sugar Planters' Association. In this paper the writer has attempted to briefly present his point of view and experience in the work for the improvement of certain economic plants through bud selection. His experience has covered about twenty years of active work with plant improvement, mainly with corn, tobacco, asparagus, citrus fruits, and some other farm crops. Individual sugar cane plant studies were begun in February, 1920, by the writer and associates of the Experiment Station of the Hawaiian Sugar Planters' Association. The writer believes that the results of this effort will be of particular scientific interest and great commercial importance.

A. D. Shamel.

March 12, 1921. 


\section{CONTENTS}

Pago
Plont

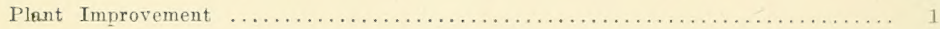

Definition of the Terms Bud Variation and Bud Selection..................2

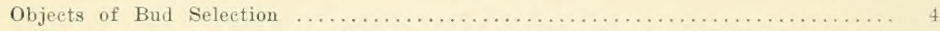

The Origin of Varieties from Bud Mutations....................... 4

The Isolation of Strains in Established Varieties..................... 12

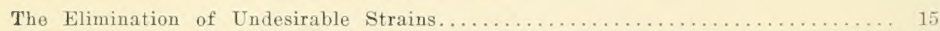

The Amelioration of Varieties and Strains Through Bud Selection.............. 15

Individual Plant Performance Records . . . . . . . . . . . . . . . . . . . 16

The Commercial Utilization of Individual Plant Records.................. 20

The Selection of Superior Parent Plants......................... 21

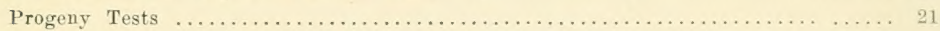

The Scientific Study of Bud Mutations and Bud Selection................. 22

Pioneers in Bud Mutation and Selection Work .................... 22

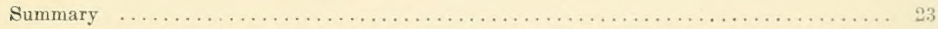

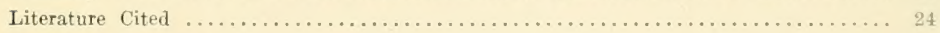

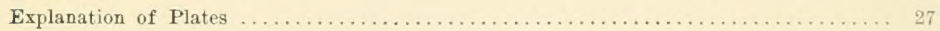




\title{
The Improvement of Plants Through Bud Selection
}

\author{
Plant Improvement.
}

We are indebted to Charles Darwin for much of our knowledge of the behavior of animals and plants under domestication $(14,15)$. His investigations established many of the principles of, and laid the foundation for, the further scientific study of organic evolution. The records of his observations and experiments with plants have furnished a large amount of fundamentally important data and reliable information which has constituted the basis for much of the recent constructive work for plant improvement. He states that the conscious or unconscious selection of superior plants for propagation by man has been carried on for about as long a time as agriculture has existed. He found in ancient Chinese encyclopedias (15), translated by the Jesuits in the 18th century, records of recommendations for the preservation and propagation of the best plants, the choice of large seeds for planting, and the history of an improved variety of rice secured through the selection and propagation of superior plants by the Emperor Khang-hi. Rice is one of the best examples of the value of plant improvement work. At the present time there exist more than 5,000 local varieties in different rice-growing districts of the world which have been developed through plant selection and propagation.

The sexuality of plants was demonstrated by Camerarius in 1691. The first hybrid of which we have a record was made by Thomas Fairchild, an English gardener, in 1719. Knight, an eminent English student of plant life, contributed a large amount of information to our knowledge of plant hybridization. Van Mons, a Belgian horticulturist, produced a number of improved varieties of plants through selection.

The re-discovery of Mendel's famous law in 1900 (3) and the publication of De Vries' mutation theory in the following year (72) marked a new era in plant improvement. These contributions stimulated a widespread interest in the study of plant improvement which has been unequaled in the history of agriculture. A large number of investigators are now devoting their entire time and energy to a study of the various phases of this subject. Many universities have inaugurated courses of instruction and study for students along these lines. A number of research institutions have been established in the United States and abroad for the purpose of investigating the fundamental principles underlying the work of plant improvement. Several commercial organizations have been built up for the sole purpose of carrying on practical plant improvement work for particular crops. As a result of this intensive and systematic activity, plant improvement has become a subject of great scientific interest and large commercial importance during recent years.

Much of the pioneer work for plant improvement has been carried on with sexually reproduced plants. In science, sex, fecundation and the behavior of hybrid plants have received the major share of attention. In practice, seed selection has been the most important phase of plant improvement work. While 
it has been known for a long time that bud variation occurs in vegetatively propagated plants, the study of this phenomenon has been somewhat neglected for several reasons. It has been quite generally believed that when an asexually propagated variety has become established no further selection is necessary. The reasons for, and the necessity of, selection of plants grown from seed have become matters of common knowledge. On the other hand, the causes of bud variations are not fully understood as yet, the extent and frequency of this phenomenon have not been determined except in the case of a few plants, and the facts concerning the importance of bud variation and bud selection in the amelioration of plants are not widely understood. Furthermore, the scientific study of seeds produced under controlled conditions and of the behavior of the plants grown from them provides particularly convenient and fascinating material for investigation and demonstration. The results of such study have often been extremely spectacular and have attracted a deservedly vital interest in the minds of the general public. These and other related conditions have naturally led to a concentration of interest, both from the scientific and commercial standpoints, in tinis phase of plant improvement and to a lack of interest in similar work with vegetatively propagated plants. The purpose of this paper is to present evidence to show that bud variations are of frequent occurrence in many plants and to suggest the importance of bud selection in the economic improvement of those plants. This discussion will be largely confined to the practical application of bud selection work in the improvement of certain agricultural crop plants which are of commercial value and importance and which are propagated without reference to sexual reproduction.

\section{Definition of the Terms Bud Variation and Bud Selection.}

The term bud variation, as we understand it, applies to any variations that take place in the soma of the plant as distinguished from the variations apparently caused by sexual reproduction and shown by the behavior of seedlings. Webber states $(77)$ in this connection * * * "from our present knowledge of the cytology of heredity we would assume that hereditary changes such as those manifested by bud variation, as well as seedling variations, are due to rearrangements of the hereditary units or anlagen which occur during cell division. In the case of seedling variation we assume that this rearrangement takes place primarily during the progress of the reduction division that precedes the formation of sexual cells. So far as microscopic investigations go we have no evidence that would strengthen the idea of such a redistribution of characters ever taking place in somatic cells. However, we have the strongest of all possible proofs that it does occur in the fact that in bud variation we get segregations of character analogous to the segregations of seedlings."

Bud variations may be divided into two general classes: (1) those which are not inherited and (2) those which are inherited. The non-heritable variations include that type of variation which is the result of environmental influence and is exhibited in the response of all kinds of plants in the same definite way to the stimulation of environmental factors. 
In this discussion we are concerned primarily with the types of bud variations which are inherited. These types may be conveniently divided into two classes, (a) bud fluctuations or continuous bud variations and (b) bud mutations or discontinuous bud variations. Castle defines fiuctuations as "those which are purely quantitative, plus or minus, as compared with the prevailing racial condition" (10). The value of bud fluctuation or continuous bud variations in the work of plant improvement is a matter of dispute amongst some investigators. The particular point at issue seems to be the possibility of changing the mode or increasing the maximum through the continuous selection of maximum bud fluctuations. The experience and observations of the writer have led him to believe that by continuous selection in isolated strains the mean of the variation in the selected population may be raised to a point more nearly approximating the maximum exhibition of the character in the strain. This conclusion has been reached as the result of study and observations in the amelioration of several of our important economic plants, among which may be mentioned the increase of the average percentage of oil, protein, and starch in the composition of maize through the systematic selection of seed possessing the maximum amounts of these elements in their composition; the increase in the yield of varieties of tobacco through the systematic selection of seed from the best individual plants; the increase in yicld of violets through the selection and propagation of cuttings from the most productive plants; the increase in the yield of potatoes by the selection of tubers from the high-yielding hills; the improvement in the yield of citrus fruits through the propagation of the best-yielding parent trees; and many other equally striking similar experiences. It is argued by some of the opponents to this conclusion that even if these improvements in plant behavior have been effected it will be necessary to continue the selection by means of which they were secured in order to preserve and maintain them. This idea may or may not be correct, and even granting that it may be sound in some cases, it does not vitiate the fundamental importance of selection in developing and maintaining improved production. It is the personal opinion of the writer that through the selection of observed bud fluctuations in any plant character, such as size, number, or chemical composition, those of genetic character will be included so that through repeated selection races will be developed which are progressively larger, more productive, or otherwise changed in the direction of the selection. From the commercial standpoint it is thought that this phase of plant breeding is the most important one concerned in the work for the improvement of plants.

The terms bud mutations or discontinuous bud variations in this discussion will be used to define sudden or marked variations from the parental forms in vegetatively propagated plants. Darwin called such variations bud sports, but this term has been largely superseded by the term bud mutation as proposed by De Vries. Many of our valuable varieties and strains of cultivated plants have originated from bud mutations. It is probalsle that amongst regetatively propagated plants a majority of the important commercial varieties lave originated in this way. In seed propagated plants, it is the writer's conviction that a consid- 
erable number of important varieties, which are commonly thought to have arisen fiom crossing, have, as a matter of fact, originated as bud mutations.

The term bud selection as used in this paper may be defined as the selection and propagation of heritable bud rariations which, for one reason or another, are better suited for cultivation than the parent plants. Bud variations are of no value in the work for the improvement of plants unless they are preserved and propagated. Their preservation depends wholly upon selection. It naturally follows, then, that bud selection is the agency through which bud variations are perpetuated and utilized in the work of plant improvement.

\section{Objects of Bud Selection.}

The fundamental objects of bud selection in the work of plant improvement may be classed as follows: (1) to secure new and better varieties of plants through the selection and propagation of striking and valuable bud mutations; (2) to isolate strains of established varieties which show characteristics of greater merit or value than those of the parent varieties; and (3) to bring the average performance of the population of a strain or variety up to that exhibited by the maximum individual performance or as nearly so as is found to be practical.

\section{The Origin of Varieties from Bud Mutations.}

An impressive number of important cultivated varieties of plants are definitely known to have originated from bud mutations $(8,15,13)$. This number is probably only a small fraction of the actual total number of valuable varieties which have originated in this way. This condition arises from the fact that many of the supposed variations in seedlings which have been selected and propagated as new varieties were doubtless the result of the seeds having come from different branches of the parent plants. These branches as a result of bud variations transmitted to the seeds their different tendencies which were discovered as variations in the plants grown from these seeds. In such instances the originators of the varieties propagated from such selected variations have often assumed that the variations were the result of hybridization or other sexual influences, when as a matter of fact they are actually the result of bud variation.

It will be possible in this paper to refer to only a small number of the known cases of valuable varieties of plants which have originated from bud mutations. A few typical instances in different plant groups will be cited in order to emplasize the importance of this factor in plant improvement work and to indicate something of the possibilities of further effort along this line.

Many varieties of roses have originated from bud mutations. Carrière ( 8 ) gives in his account of bud varieties published in 1865 a list of fifty standard rose varieties known to have originated from bud mutations and states that no attempt was made to make the list complete. The 1919 Annual of the American Rose Society contains a list (25) of 429 varieties of American roses, of which 116 , or more than 25 per cent, are definitely known to have originated from bud mutations, for the most part within the past twenty-five years. Carrière ( 8 ) 
and Darwin (15) both present eridence, which has been confirmed repeatedly, that the moss rose varieties have originated from bud mutations and, in turn, smooth branch varieties have sprung from moss varieties through bud variations. For example, the common double moss rose originated from the smooth-bran Provence rose by bud variation. The moss rose has produced the Provence rose in which the branches are partially or wholly destitute of moss.

From the Killarney rose, solid pink in color, a large number of varieties have been secured through the selection of bud mutations (38). These bud varieties have differed in color from white to red, in flower arrangement from semidoubles to doubles, and in habit of growth from bush to climbing forms. Amongst these varieties may be mentioned the White Killarney, Dark Pink Killanney, Champ, Weiland, Killarney Queen, Double White Killarney, Double I'ink Killarney, Red Killarney, Killarney Brilliant, Climbing Killarney (pink), and Climbing White Killarney.

The Ophelia, a pink rose, is a variety of comparatively recent introduction which is deservedly poptular at the present time. This variety is very prolific in the production of bud mutations (71), the most important of which include the Opleelia Supreme, having light rose-pink flowers; Rosalind, with coral-pink flowers, changing to apricot-pink; Silvia, having stlphur-yellow flowers, changing to creamy shaded; Evelyn, with larger flowers of a deeper shade and larger blooms; Rose Pink Ophelia, having smaller flowers but flowering more freely than the Ophelia; May Martin, with mustard-yellow flowers; Madame Butterfly, with flowers of greatly intensified color; I White Ophelia, having white flowers; and other varieties with flowers of varying shades of color and different types of foliage.

The rose varieties having a climbing habit of growth have practically all originated as bud mutations from bush forms (25). Examples of this phenomenon inclule the (limbing liriclesmail, the Climbing (écile lirunner, the (limbing Frau Karl Druschki, the Climbing La France, and the Climbing Rhea Reid. The 1919 Annual of the American Rose Society contains a list of 34 climbing varieties of recent American origin which have been propagated from bud mutations $(25)$.

In chrysanthemums, a large proportion of the present cultivated varieties have originated from bud mutations. Cramer (13) presents a list of 400 bud varieties of the chrysanthemum. From this list of bud varieties the following examples are presented:

$$
\text { Parent Variety. }
$$

Alcester (Lord), 1882.

Inflected, butter.yellow.

Andiguier (Edward), 1886.

Jap., brown, purple,

silver back.

Avalanche, 1887 .

Snow-white.
Bud Variety.

Mr. Robert Murdie, 1888.

Inflected, salmon-yellow.

Mrs. William Walters, 1887. The Garden, 88, II, 498.

Jap., Carmine,

bronze-gold back.

Edw. Beckett, 1892.

Jap., dark gold-yellow.
Authority.

The Garden, 90, I, 145.

de Meulenrese, II, 49. 
In 1822, twenty-seven varieties of chrysanthemums were cultivated in England, part of which had been imported, and some of which had originated from the imported varieties through bud mutation. In 1836 three Chinese varieties were imported which bore pink, speckled, and flesh-colored flowers, respectively. The next year a single plant bore all three of these forms.

Chrysanthemum bud mutations frequently occur in the branches of the plants and occasionally in the suckers. They may be propagated in either form. The stability of the bud mutations must be determined by experimental propagations unless it is a type which is known to be transmitted. The practicability of this effort is shown by the fact that of the 8.800 varieties cultivated in Europe in 1899 more than 5,000 were originated in this way.

In carnations, many of the valuable cultivated varieties have originated as bud mutations. Dorsey (18) mentions among the important commercial bud varieties the Victor, Chicago, White Lawson, White Enchantress, Rose Pink Enchantress and Enchantress Supreme.

In hibiscus, Darwin ( 15 ) mentions several striking bud mutations, including one where the bud variation produced flowers and leaves resembling in shape those of another species. Both the parental form and the bud mutation were extensively propagated by cuttings and came perfectly true. Stout (69) records the origin of a clwarf form of Hibiscus oculiroseus as a mutation. Carrière (8) cites two instances of varieties of hibiscus originating from bud mutations, viz., H. syriacus, variety flore pleno variegata, with variegated yellowish-white leaves, appearing in a green-leaved plant in 1858 , and $H$. syriacus, variety caricgata, with remarkably variegated leaves, an example of which is shown in Plate $I$. While in Honolulu in 1920 the writer's attention was called to several cases of bud mutation in hibiscus plants, including double flowers borne by single-flower plants and the development of branches having very different foliage on the same stem.

In dahlias, Darwin (15) cites the case of the Butterfly variety, in which the same plants produced double and single flowers, "here white petals edged with maroon, there of a uniform deep maroon." He also records the instance of a plant which bore two different kinds of self-colored flowers as well as a third kind which partook of both colors beautifully intermixed. Similar illustrations of bud mutations in dahlias have been repeatedly observed in gardens in southern California during recent years by the writer, an example of which is shown in Plate 2. The Le Grand Manitou, a leading dahlia variety having white flowers with purple stripes, has produced a purple-flowered variety, the Purple Manitou, as shown in Plate 3 , by bud mutation which is being cultivated at the present time to some extent.

Many other instances of varieties of common flowering plants arising from bud mutations might be mentioned. Bud varieties of the Sweet William, SnapDragon, Stocks, Cyclamen, Gladiolus, Fuchsia, Violet, Hydrangea, Geranium, and Evening Primrose are widely cultivated by gardeners and florists. We be- 
lieve, however, that the examples already given are sufficient to show the importance of this phenomenon in the work for the improvement of flowers.

With ornamental plants the selection and propagation of bud mutations has provided a large number of valuable varieties for cultivation.

The Euonymus varieties are amongst the most valuable and widely grown of all ornamental plants. Carrière (8) calls attention to five bud varieties of E. Japonica, viz., argentea, aurea, flavida, fasciata, and calamistrata, and states that many other varieties which differ in variegation or sometimes by the form of leaves have been produced by the selection and propagation of bud mutations.

Roeding ( 40 ), one of the leading plant propagators in California, propagates and distributes the following varieties of $E$. Japonica which he personally told the writer in August, 1919, were originated from bud mutations: Albo-marginata (silver-margined), albo-z'aricgata (silver-variegated), aureo-zariegata (goldenvariegated), columnaris (tall-growing), viridi-z'ariegata (Duc d'Anjou), aureomarsinata (golden-margined), and microphylla (dwarf form). The writer recently has found all of these variations occurring as bud mutations in Euonymus plants growing in the vicinity of Riverside, an example of which is shown in Plate $\frac{4}{4}$, and has complete evidence as to the origin of the above mentioned cultivated varieties from bud variations.

Pittosporum varieties are now widely grown as ornamental lawn plants and for shrubbery. They rank in importance in this respect with the Euonymus varieties. Carrière $(8)$ mentions that $P$. Tobira varicgatum originated from $P$. Tobira as a bud mutation. This variegated-leaved variety is one of the most popular ones in California and has been repeatedly found by the writer (52) occurring as bud mutations in the green-leaved parental form. Other mutations of $P$. Tobira, differing in leaf-form and variegation, have been observed by the writer in plants growing in the vicinity of Riversicle, California, an example of which is shown in Plate 5. Some of these have been isolated through bud selection and are now being cultivated to an increasing extent, an illustration of which is shown in Plate 6.

In Coleus, Stout $(70)$ found that bud variations are common and give rise to numerous different types which may be quite constant from the first or can be made so by selection. In pedigree cultures he isolated 15 distinct varieties through bud selection which were characteristically different in color patterns. He concludes from his investigations that in Coleus asexual and sexual reproduction are not fundamentally different in respect to the extent and range of variation.

In ferns, Boshnakian (6) states that in the common Boston fern (Nephrolepis craltata bostonicnsis) over 6,5 commercial varieties have originated as bud mutations since 1898.

In the Oleander ( Nerium olcander), one of the oldest of cultivated ornamental plants, the writer found in 1918 near Thermal, California, a branch bud mutation having variegated leaves borne by green-leaved plants, as shown in Plate 7 , and uniformly variegated plants which had been propagated from similar mutations. 
In Irish potatoes, Carrière (8) shows that many striking bud mutations occur which have been preserved through selection. East (19) records bud mutations as shown by the color, shape, character of eyes, and habit of growth, of the tubers which remained constant in propagation. Gilbert (26) says that the principal method of improving the Irish potato is through bud selection.

In the sweet potato, H. C. Thompson, formerly horticulturist of the U. S. Department of Agriculture, in a personal statement in 1917 informed the writer that this plant is exclusively propagated vegetatively and that all commercially grown sweet potato varieties have originated as bud mutations.

In apples, Hedrick (28) describes four strains which are now commonly accepted as varietics of the Twenty-ounce-which originated as bud mutations. Farmer (23) describes the Oswego variety as originating as a bud mutation of the Northern Spy. Fletcher (2t) gives an account of the Chesebro Spy variety which originated as a bud mutation of the Northern Spy. Mead (3t) records a mutation of the Gravenstein variety having fruits with solid red color which has been propagated through bud selection. A seedless mutation of the Porter apple was discovered and called to the writer's attention by J. A. Dorrance at Scotland, Connecticut, in 1913. This consisted of one of the main limbs in an old tree. It has borne similar fruits each year since then and has been propagated. Beach (4) describes the Banks apple as a nutation of the Gravenstein variety, the Collamer as a sport of the Twenty-ounce, and the Red Russet and Olympia as mutations of the Baldwin variety. Castle (9) refers to two strains of the Wriliams apple, one having conspicuously striped fruits and the other having neariy solid red color. Other striking mutations in apple varieties have been observed, an example of which is shown in Plate 8 , including red and russet variations of the Rome $(1,2)$, oblong-shaped Grimes (1), solid dark-red varialions of the striped Ben Davis, and various shaped fruits in Baldwin apple trees observed by the writer at Seymour, Connecticut, during recent years in individual tree performance record plats of trees of these varieties in the J. H. Hale orchards.

In peaches, Darwin (15) records peach trees producing buds which when developed into branches yielded nectarines and that six named and several unnamed varieties of the peach have thus produced several varieties of the nectarine. Carriere ( 8 ) describes two varieties of the peach, the carnation-flowered, having a flesh-rose color, and the many-colored-flowered, possessing white striped colors, which originated as bud mutations. He also gives the willow-leaved red Madeleine and the laciniate-leaved red Madeleine as varieties originating as bud sports. Fletcher (24) mentions a white-fleshed clingstone or semi-freestone variety originating as a bud mutation of the Early Michigan. Powell (40) records the propagation of an early ripening mutation of the Mountain Rose peach. The writer found several branches in Elberta trees in the performance-record plat of this variety in the J. H. Hale orchards at South Glastonbury, Connecticut, in 1912, bearing fruits without pubescence and otherwise apparently identical with fruits of the new J. H. Hale variety. Furthermore, branches were found in 
J. H. Hale peach trees hearing typical Ellerta fruits, indicating that the I. H. Hale variety originated as a bud mutation. The writer also observed branch mutations in yellow-fleshed-fruited Elberta trees bearing white-fleshed fruits but otherwise like the Elberta fruits.

In prunes, a large-fruited variety Coates No. 1418, an illustration of which is shown in Plate 9, originating as a bud mutation of the French prune, was described by the writer in 1919 (57). Coates propagates commercially no less than three varieties of the French prune which have originated as bud mutations (11). Darwin (15) records that a tree of yellow Magnum Bonum plum, forty years old, produced a branch mutation which loore red Magnum Bontmins.

In grapes, Carrière $(8)$ states that bud variation is comparatively common. Amongst other examples he cites the origin of the white seedless Corinth as a mutation from the parent seedy variety. Fletcher (24) records the King, a bud variety of the Concord. Paddock (37) gives mammoth or giant forms of the Concord identical with Eaton as originating from bud mutations of the Concord. Ballow (1) records a bud variety of the Concord with exceptionally large berries which came true under his observation for two successive crops. The Pierce variety originated as a bud mutation from Isabella, according to Le Long (33). The writer has photographed bud mutations of the Thompson seedless grape, as shown in Plate 10, with conspicuonsly large berries and different foliage than that of the parent form from the vineyard of C. L. Edmunds of Thermal, California. Roeding has introduced and propagates commercially a mammoth or giant Thompson seedless variety which he has stated to the writer originated as a bud mutation.

In pears, Carrière $(8)$ says that the following varieties have given by bud variation variegated varieties, Dtchesse d'Angonléme, Amanlis, Guenette, SaintGermain, Bergamotte d'Automne, Culotte de Suisse, and others. The writer observed and photographed in 1918 in commercial pear orchards near Tehachapi, California, limb mutations in Bartlett pear trees bearing striped fruits and in other instances fruits possessing very different characteristics of shape, size, and color from the normal fruits on the same or neighboring trees, as shown in Plate 11. Evidence was found to indicate that several of the strains of the Bartlett variety in those orchards, including the Winter Bartlett, the Sheep's Nose Bartlett, and Corrugated Bartlett, originated as bud mutations.

In strawberries, Farmer (22) states that the Pan-American, an ever-bearing variety, originated as a bud sport of the Bismark.

An illustration of bud variation in the artichoke is shown in Plate 12.

In citrus fruits, the investigations of the writer in Brazil in 1913 (17) indicate that the Washington Navel orange, atypical tree of which is shown in Plate 13, one of the most important fruit varieties in existence, originated as a bud mutation of the Selecta variety at Bahia, Brazil, and was first propagated in 1820. Reasoner (45) states that the Foster, a variety of grapefruit producing pink-colored fruits, originated as a bud mutation of the Walters variety. In a letter to the writer dated August 6, 1915, Reasoner describes a pink-fleshed mutation of the Marsh grapefruit. A similar mutation was found by the writer in 
a Marsh tree on the L. V. W. Brown ranch at Riverside, California, in 1919 (61). Conner (12) propagates commercially a variety of grapefruit, the Conner Prolific, which he states originated as a bud mutation of the Bowen. The writer has isolated through bud selection in the Marsh grapefruit variety, as grown in California, a mutation having conspicuously flattened and commercially seedless fruits $(54,66)$. An illustration showing a typical fruit of this strain is shown in Plate 20. It is of much greater commercial value than the parent variety and is now being extensively propagated by nurserymen in California.

In cotton, the Pima, the Yuma, the Gila, and the Somerton, improved long staple varieties, originated as mutations, according to Kearney $(29,30,31)$, their originator, and are amongst the most important commercially in the United States.

In tobacco, the writer (47) in 1904 in the Connecticut Valley originated the Hazlewood variety as a mutation of the Cuban variety. This variety has furunshed the foundation for one of the important agricultural industries in America. In 1903 and 1904 the writer secured through the selection of mutations the Uncle Sam Sumatra, which is grown commercially in Florida. Georgia, and Alabama; the Halladay, which is extensively grown in the Connecticut Valley, and other commercial tobacco varieties.

In the cacti, Griffiths (27) records the origin of several spineless varieties as bud variations of spiny forms.

In corn, Emerson (21) records the occurrence of recurring somatic variations in variegated ears. De Vries (74) describes mass mutations in maize and (73) other forms of mutation, including unbranched varieties, loss of starch in the grains, and dwarf forms. East and Hayes (20) report various forms of somatic mutations in corn, including dwarf, bifurcated, and branched ears.

In sugar cane, Carrière (8) mentions this plant as one which shows a large number of distinct bud varieties. Darwin (15) states that sugar cane is one of several plants that sometimes produce new varieties from the stock or root. He quotes Caldwell (7) as saying that the Ribbon cane has sported in Mauritius "into a perfectly green cane and a perfectly red cane from the same head. I verified this myself, and saw at least 200 instances in the same plantation and the fact that completely upset all our preconceived ideas of the differences of color being permanent. The conversion of a striped cane into a green cane was not uncommon, but the change into a red cane, universally disbelieved, and that both events should occur in the same plant, seemed incredible. I find, however, in Fleischman's 'Report on Sugar Cultivation in Lonisiana for 1848 ' by the Anerican Patent Office, the circumstance is mentioned, but he says he never saw it himself."

The Commissioner of Agriculture for the West Indies (35) reported several justances of striking bud mutations in sugar cane that had recently come to his attention, and presented colored illustrations of two of them. (An abstract of this article with black and white reproductions of the illustrations has appeared in the Journal of Heredity (39).) These observations were summarized as follows: 
1. Bud variations occur in the sugar canc.

2. They have been recorded from widely-separated countries,-Mauritius, Lotisiana, West Indies, and Queensland.

3. The difference between sport and mother-plant are often as considerable as those between recognized distinct varieties of the sugar cane.

4. Bud variation may give rise to :-

(a) Differently colored side shoots on one cane.

(b) Differently colored canes in one stool springing from the same mother plant.

(c) A cane with some joints striped and some unstriped.

5. Plants grown from cuttings of the sports tend to come true to color.

6. The cane giving rise to sports, whenever recorded, has been a striped or ribbon cane.

The observations of other writers have disproven this last conclusion, as is shown by Deerr's account of the Horne variety mentioned below. Some bud varieties of cane also show differences in hardiness and in sugar content.

Deerr (16) states that the Lahaina and Bourbon varieties originated as bud inutations from the Mignonne variety. He records that the yellow-violet Cheribon and purple-violet Cheribon varieties originated as bud mutations of the ribbon cheribon variety and that the white and black cheribon are bud varieties of the ribbon cane. Also that the White Tanna and Black Tanna varieties originated as bud sports of the Striped Tanna. The Rose Bamboo and Purple Bamboo varieties arose from mutations of the Striped Bamboo, and the Yellow Tip variety originated as a bud mutation of the Striped Tip. Deerr says that the Horne variety is of particular interest because it is one of the earliest, if not the earliest, recorded instance of a striped cane originating from a self-colored cane as a bud mutation. He also cites the Green Rose Ribbon variety originating as a bud sport of the Otaheite variety. In the striped cane known as the Tsimbec, a variety called the Iscambine rouge arose from a bud mutation. He says that the Branchu blanche is a self-colored sport from the Branchu rayee. Further, he records the case of green and yellow ribbon cane springing from the Yellow Caledonia.

In December, 1890, Mr. John Horne (35), then Director of Forests and Botanical Gardens, Mauritius, in a letter to the Director of the Royal Gardens, Kew, published in the Kew Bulletin for 1891, wrote: "Of new varieties originating as bud sports we have eight or nine in Mauritius alone; some of them very fine canes and they are cxinsively planted. Most of them are hardier than thei: parents and they yield more sugar. They are mostly obtained from new canes recently introduced. The sudden change of climate, soil, and other circumstances cause them to be thrown off. More of them might be obtained if the planters were more observing than they are and closely followed the cane cutters throughout their fields. As things are, a new variety is only observed should it chance to spring up in an outside row."

The Hawaiian Sugar Planters' Association Experiment Station has collected a large amount of information showing the frequent occurrence of bud mutations in sugar-cane varieties grown in the Hawaiian Islands. 
The writer is of the opinion that systematic economic bud selection work with sugar cane will give particularly early and striking results in the way of improved sugar production per acre, which will be worth millions of dollars annually to the industry.

The simple elimination through bud selection of some of the undesirable strains arising from bud mutations in the established varieties will in itself achieve this result. This work can be carried on without any possibility of loss to the industry or the rearrangement of any of the methods of culture other than that of securing seed cane for planting. The cost of this work will be very small in comparison with its value. The increased production of sugar through the culture of uniform and superior varieties will be effected at no greater cost than that previously sustained when growing the more variable varieties with their resulting lower yields.

In pineapples, the writer observed in May, 1920, amongst the plants in a commercial field of the smooth Cayenne variety grown on the Island of Oahu, T. H., many apparent striking bud mutations. The leaves of some plants were smooth while others were sharply serrate. The shape of some of the fruits was cylindrical, while in other cases it was pyriform, ovate, obovate, globular, or modifications of these shapes. About 25 per cent of the plants had no fruits, while others were bearing fruits of different stages of ripeness. Some of the plants observed possessed a single crown, while others had multiple crowns. Frequent examples of plants having distinct strain characteristics, apparently originating as bud mutations, were found, indicating that bud variation is of common occurrence in this variety.

The above list of varieties arising from bud mutations contains only a few of those on record. Furthermore, the recorded instances constitute only a small part of the total number of such cases. This condition exists to a large extent hecatse most observers have not realized the possibility of the occurrence of bud mutations and their relation to the production of new varieties. For this reason it has been quite generally believed that bud varieties are fixed, and any new forms discovered in them have usually been ascribed to seed origin. Enough instances have been given to prove the importance of bud mutations in plant improvement work, and particularly so in the case of those plants which are vegetatively propagated.

\section{The Isolation of Strains in Established Varieties.}

The term strain as here used designates a group of individuals of an agricultural variety differing from all other individuals of the variety in one or more constant and recognizable characteristics and capable of perpetuation. This discussion will be largely confined to regetatively propagated strains which in scientific literature are frequently referred to as ciones, as suggested by 11 eblorer (70).

Strains oftentimes arise from the unintentional propagation of bud mutations. For example, the writer and his associates have found in their study of the Washington Navel orange (64) that this variety as grown under California conditions has given rise to fourteen strains through bud mutation within a few 
bud generations. Typical fruits of some of these strains are shown in Plate 14. These strams for the most part hare been unintentionally propagated by nurserymen and others. Some of them have been found to be very undesirable from the economic standpoint, while others apparently possess some value for particular conditions of culture.

Varieties of economic value and importance often degenerate or rum out through the unintentional or intentional propagation of undesirable strains originating as bud mutations. In the Washington Navel orange variety as grown in California, the writer has found that the undesirable Australian strain, having rank-growing trees, an example of which is shown in Plate 15, which characteristically bear small crops of fruit of inferior quality, as shown in Plate 16, has in some instances been propagated to such an extent as to render the variety an unprofitable one. In a few cases the Australian strain has been intentionally propagated by nurserymen because of the vigorous, hardy growth of the trees and owing to a lack of knowledge of their fruiting habits. However, the propagation of the Australian strain has usually been unintentional. The trees of this strain produce unustal numbers of vigorous-growing branches, frequently called suckers. This growth was formerly highly prized and commonly used for the propagation of the Navel orange variety in California. Inasmuch as the supply of such bud-wood was much more abundant in Australian trees than in the highvielding and desirable trees, budkers naturally secured more bud-wood from the Australian than from the Washington or best strain trees where it was obtained without regard to fruit production.

The isolation of the valuable strains of commercial varieties through bud selection is one of the important factors in plant improvement work. After strains have been isolated, their value for cultivation determined, and their characteristics recognized, they are frequently classed as agricultural varieties.

In potatoes, Myers (36) reports the results of hill selection from high-yielding and low-yielding strains of potatoes in New York. The Cornell experiments showed a five-years average yield of three low-yielding strains of $\$ 2$ busluels per acre as compared with a five-years' average yield of three high-yielding strains of 208 bushels per acre. The increase in yield secured through bud selection in these experiments amounted to an average of 126 bushels per acre. Similar results were obtained by Daniel Dean (36) of Nichols, N. Y., who began hill selection with his variety of potatoes in 1904 and whose records show a difference in production in his high-yielding as compared with his low-yielding strains of 280 bushels per acre in 1912 and 140 bushels per acre in 1913. The difference in 1913 would have been greater except for an early frost. G. D. Brill in one year's hill selection work secured an increase of 107 bushels per acre as shown by the differences in yields of a high-yielding as compared with a low-yielding strain of the same commercial variety (36).

The comparative yields of high-and low-yielding strains of the Carmen No. 3 potato variety isolated through hill selection during 1904, 1905, and 1906, are * reported by $\mathbf{W}$ aid (75) of the Ohio Agricultural Experiment Station. In these experiments the high-yielding strain produced a three-years' average of 774 
bushels per acre as compared with an average of 492 bushels per acre for the low-yielding strain, and a yield of 607 bushels per acre secured from seed tubers selected without reference to individual hills. The high-yielding strain produced an average of 262 bushels per acre, or about 35 per cent more than the lowy ielding strain, and 167 bushels per acre, or about 22 per cent, more than the cineck as the result of three years of bud selection work. His studies showed ciearly that with few exceptions the low-yielding plants remained unproductive and that the high-yielding hills for the most part remained productive, as was also sinown to be the case in the Cornell experiments referred to above.

In citrus varieties, the writer and his associates have recorded the behavior of 14 strains of the Washington Navel orange $(6+)$ ftypical fruits of some of these strains are shown in Plates 17, 18, and 19\}; 12 strains of the Valencia orange (65); 7 strains of the Marsh grapefruit (66) [typical fruits of two of these strains are shown in Plates 20 and 21 1; 8 strains of the Eureka lemon $(67)$ [typical fruits of three of the strains are shown in Plates 22, 23, and 2t] ; and 6 strains of the Lisbon lemon ( 68 ) [typical fruits of several strains are shown in Plates 25 and 26]. These strains originating as bud mutations have, for the most part, been unintentionally propagated. They have been found to be capable of perpetuation through bud propagation. The isolation of the valuable strains and the elimination of the undesirable ones through systematic bud selection has been demonstrated to be possible and commercially practicable.

In timothy, Webber (78) found great differences experimentally and commercially in the yield of high-and low-producing strains isolated through bud selection. Experimentally, he shows that the high-yielding strains produced an average of more than six times the yield of the low-yielding strains.

In prunes, the writer has begun the study of the behavior of seven strains. originating as bud mutations of the French prune variety in California; an example of one of these mutations is shown in Plate 9. The data are incomplete as yet, but enough information has been secured to warrant the statement that these strains are very different in fruit and foliage characteristics and that these differences are of great commercial importance to the prune industry.

In sugar cane, the writer and associates in the Hawailan Sugar Planters' Experiment Station during 1920 found in fields of the H 109, the Yellow Caledonia, and the D 1135 varieties many plants resembling distinct strains. Their appearance and occurrence indicated that they originated as bud mutations. The plant differences found in these strains included the number of stalks of each stool and their habits of growth, weight, length, circumference, shape, and color of stalks, amount of juice in the stalks and its sucrose content, and other important characteristics. These data are not complete as yet, nor available for publication, but it is likely that they will be announced when these investigations have proceeded far enough to warrant this action.

Most of the work in the isolation of strains has not been reported because such records have usually been withheld until the strains have been tested and introduced as varieties. In strawberries (5, 32), apples $(41,42,43,44)$, and 
other crops such work has been reported upon, but the writer feels that it is not necessary here to quote them in order to demonstrate the importance of this work. The isolation of valuable commercial strains arising as bud mutations of established varieties in vegetatively propagated plants has been found to be practicable, and it seems likely that the work can be made increasingly useful when once its importance is more generally understood.

\section{The Elimination of Uniesirable Strains.}

The undesirable strains in established commercial varieties arising from bud mutations include those in which the plants produce unsatisfactory and umprofitable crops. For example, the Shade-tree strain of the Eureka lemon, (67) an illustration of which is shown in Plate 27, which has been found by the writer and his associates to constitute more than 25 per cent of the population in some lemon orchards. The trees of this strain produce low yields of coarse thick-rind fruits, lacking in juice. The culture of these trees has been found to be unprofitable wherever investigated on account of their poor production. A number of lemon orchards have been continuously unprofitable from this cause alone. The elimination of the trees of the Shade-tree strain in established orchards through top-working them with buds secured from productive trees of the desirable Eureka lemon strain, an illustration of which is shown in Plate $2 \mathrm{~S}$, has resulted in the development of heavy-bearing trees and profitable orchards.

In established orchards or plantations where individual trees or plants of undesirable strains are discovered, such trees or plants can be successfully eliminated by top-working with carefully-selected buds or grafts secured from desirable parent trees, as shown in Plate 29 , or by replanting with young trees or plants of a desirable strain. In the propagation of young trees or plants the elimination of the undesirable strains can be effected by using as parent trees or plants only those individuals which are known not to transmit the undesirable strain characteristics.

The purity of commercial bud varieties can be maintained by eliminating or avoiding the propagation of the undesirable strains which frequently originate as bud mutations; examples of such mutations are shown in Plates 30, 31, and 32. The improved varieties of plants are the most valuable and precious possession of agriculture. Without selection most varieties are known to degenerate and run out, largely due to the appearance of undesirable and unprofitable strains. Therefore, the importance of purifying the proven and established varieties through the elimination of undesirable strains must be obvious to every thinking and unprejudiced person.

\section{The Amelioration of Varieties and Strains Through Bud Selection.}

The term amelioration of varieties and strains as here used may be defined as the keeping up or the bringing up of the average performance of the individuals to that shown by the behavior of the best individuals in the variety or strain through bud selection. The writer is of the opinion that from a commercial standpoint this phase of plant improvement is the most important one of 
all. This work can be accomplished (1) by means of individual plant performance recorils whereby the best individual parent plants for propagation can be found, and (2) through the propagation of the superior plants selected on the basis of performance records and progeny tests.

\section{Individual Plant Performance Records.}

Individual plant performance records for plant improvement work include systematic records, for as long a period as is found to be necessary in order to determine the inherent plant characteristics, of the quantity and commercial quality of the crop, the variability of the product, the season of production, the habit of growth of the plant, and any other data likely to be of value in judging the behavior and value of the plant. In order to illustrate this work the method of securing individual citrus tree performance records as carried on by the writer and his associates in southern California for the past eleven years will be briefly described $(48,49,51,64)$. There have been two phases in the evolution of this work-first, the investigational, and, second, the commercial. In the investigational work carefully-selected plats of alsout one hundred full-bearing trees each were located in several of the best commercial orchards of the Mashington Navel orange, the Valencia orange, the Marsh grapefruit, the Eureka and Lisbon lemon varieties. These locations were decided upon with particular regard to environmental influences and cultural conditions, so that reliable data of inlerent tree characteristics could be secured. The location of two orchards in which the investigational tree performance records were secured is shown in Plate 33.

Each individual tree in these plats was given a number so arranged as to both identify and locate it. This number was painted on the tree trunks with pure white lead paint, always in the same relative position and so as to be easily legible and conveniently found when desired.

The fruits from each tree were picked by or under the immediate supervision of the writer or his associates by expert pickers for the entire period of the investigation. The fruits from each tree were studied immediately after picking, as shown in Plate 34. They were assorted into the standard commercial grades for the variety. The fruits of each grade were then assorted into the standard commercial sizes for the variety. The weight and number of fruits of each size in each grade were then carefully determined by the writer or his associates. So far as possible, the same man conducted this work in each plat every year in order to avoid differences due to the personal equation. After weighing and counting each lot, the fruits were examined for variations and the number of variable fruits of each class was recorded, as shown in Tables 1 and 2. During the course of this performance record work descriptions of tree and fruit characteristics were recorded. These studies were conducted on a total of 858 Washington Navel orange trees, 179 Valencia orange trees, 253 Eureka lemon trees, 128 Lisbon lemon trees, $10+$ Marsh grapefruit trees, and a number of trees of several citrus varietics of minor commercial importance. These records covered periods of 4,6 , and 8 successive years, as the circumstances warranted, in order to carry out the purposes of this investigation. The work entailed a large amount of 
TABLE 1.-ORANGE PERFORMANCE RECORD.

DATE: Feb, 24, 1914. STRAIN: Washington. LOCATION: Highgrove, California.

GROWER: National Orange Company. GROVE: Vivienila.

VARIETY: Washington Navel. PLOT: 3. ROW: 14. NO. OH TREE: 27.

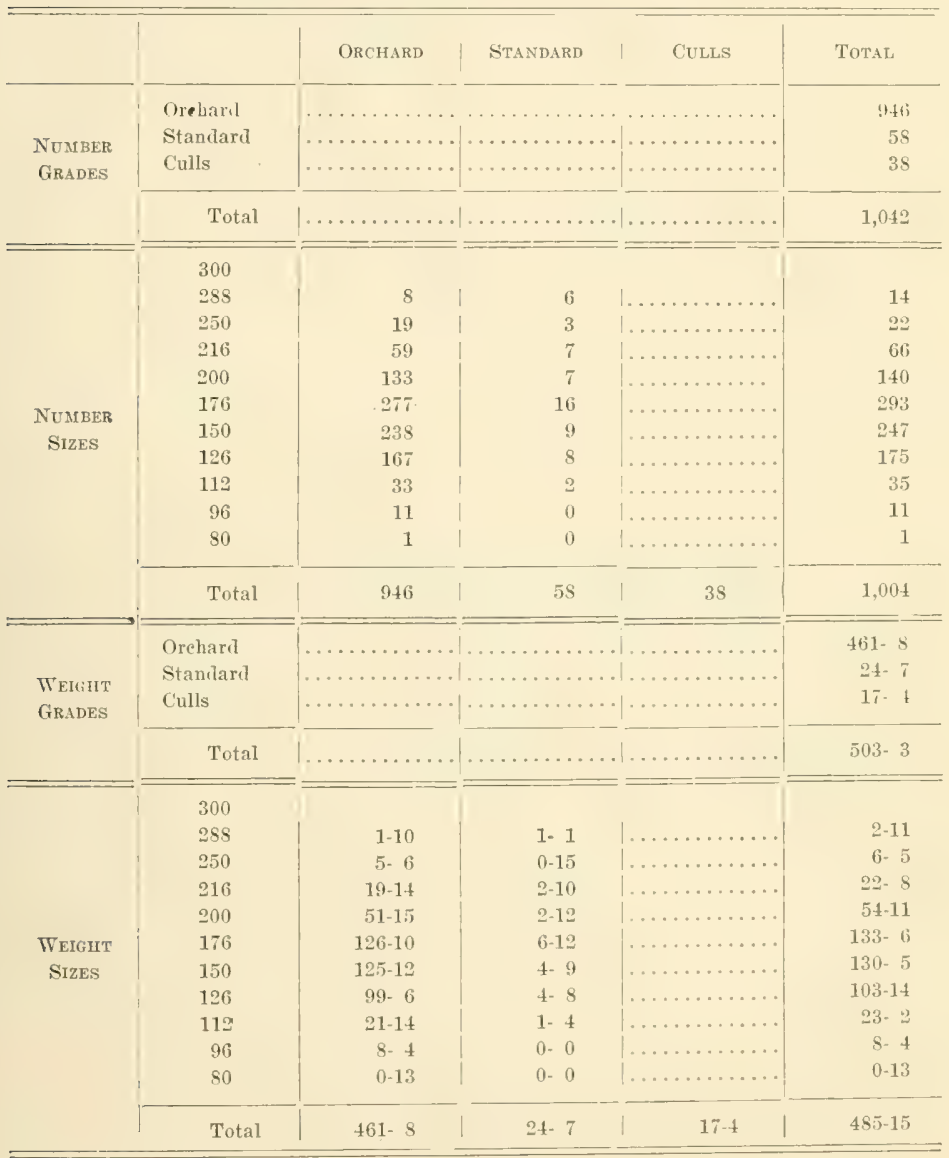

Notes:-Fine quality. 111/2 boxes.

\section{SPORTS}

Australian .......... 1

Wrinkled ...........

Flattened ...........

Corrugated ............

Protruding ........ 3

Yelluw .............

Ridged ........... 3

Ribbed
Creased

Very smooth .........

Coarse

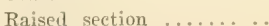

Sunken section ..........

Rialsed iml sunken......

Yellow section .........

Golden nugget ........
Abnormal sluape ..... 1

Split navel .......

Split sicle ........ 3

Pear shape ..........

Elliptical ...........

Lumg ..............

Striped

Off bloom 
TABLE 2.-ORANGE PEHFORMANCF RECORD.

DATE: 1910-1915. STRAIN: Washiugton. LOCATION: Highgrove, California. GROWER: National Orange Company. GROVE: Vivienta.

VARILTY: Washington Navel. PLOT: 3. ROW: 14, NO. OF TREE: 27.

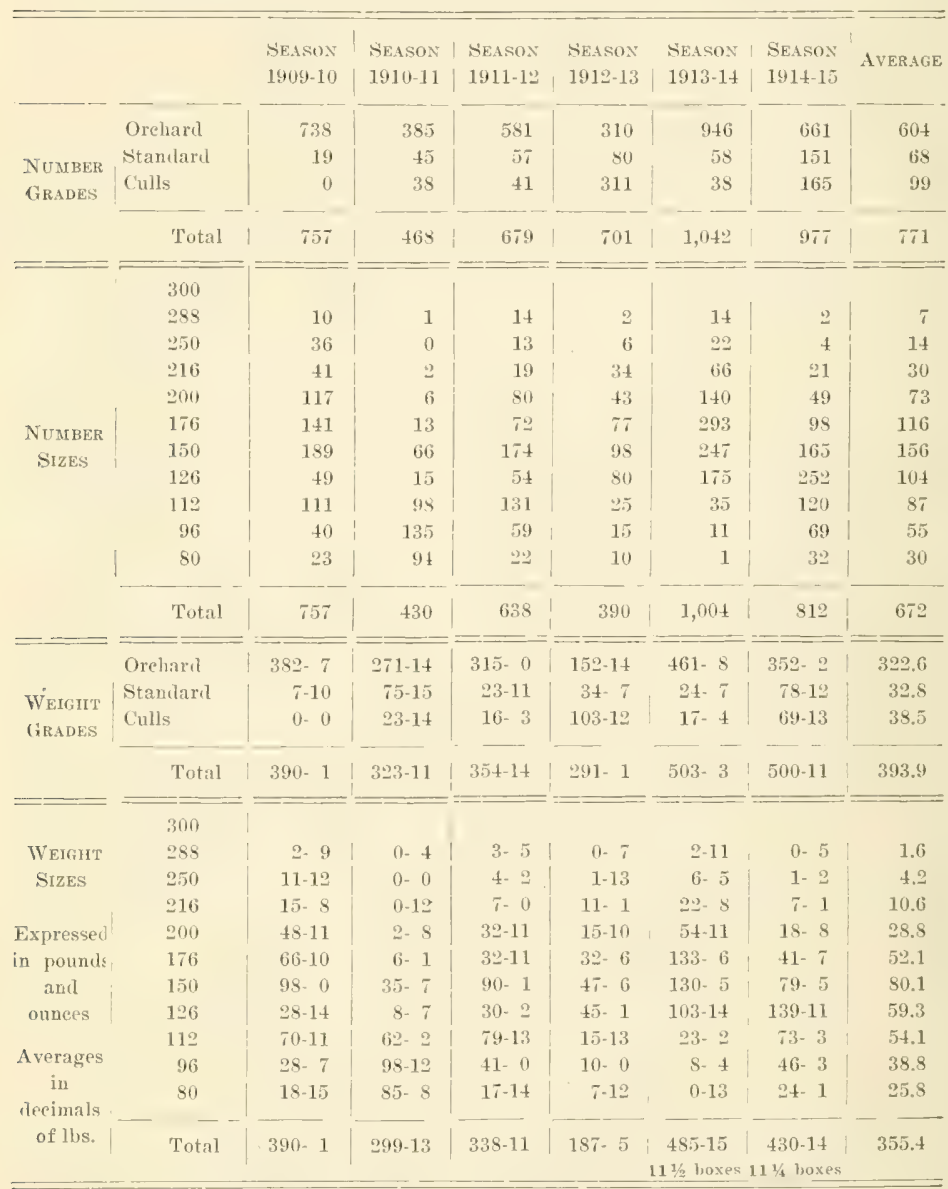

Notes:-Abrahsm Lineoln tree. Fruit is fine colorel, large, and smooth. 
systematic attention and required sustained effort. Some of these records are being continued in order to secure further and more complete information upon certain phases of tree behavior and additional data of some tree and fruit characteristics.

These investigations have revealed the occurrence and frequency of bud mutations in the varieties studied, an example of which is shown in Plate 35 , the existence and extent of occurrence of the various strains arising from bud mutations and their comparative commercial value, the tree and fruit characteristics of the trees of these strains, and other information of fundamental importance to the citrus industry. In the course of this work improved methods of propagation have been discovered and developed, such as the use of fruit-bearing budwood for propagation, an example of which is shown in Plate 36, instead of the sucker growth which was formerly used for this purpose. Illustrations showing the method of using this bud-wood in propagation are shown in Plates 37 and 38. Individual tree performance records of pruned and unpruned trees of each of the commercially important varieties led to the discovery of the very injurious and disastrous effects of early or severe pruning (55, 58, 63) with healthy; normal citrus trees. This information has resulted in the general abandonment of such practices amongst citrus growers. The individual tree records, showing the behavior of trees grown under different methods of soil fertilization, led to the origination by the writer of an improved system of applying organic fertilizers in citrus grchards called the furrow-manure method $(53,56,62)$, which has proven to be more economical and efficient than any formerly used. A study of the behavior of the fruits from the lemon performance-record trees in curing rooms led to the discovery of the importance of a uniform condition of atmosphere humidity in the curing of lemons and other citrus fruits and to the invention of a humidifier for securing and maintaining the optimum conditions ( 50 , 59). Other results might be cited, but the above are considered to be sufficient to show the importance of this work.

The results of the investigational citrus tree performance record work naturally led to the development and use of commercial tree performance record work by citrus growers for the following purposes: (1) to locate drone trees of undesirable strains in the established orchards for top-working or replanting; (2) to locate, if possible, superior trees as sources of bud-wood for propagation; (3) to determine the results of cultural experiments or tree treatments; and (4) to carry on intelligent individual tree care in the orchards. Up to the present time, 1921, commercial tree records have been kept in more than 50,000 acres of citrus orchards in California and in considerable citrus acreages in southern Alabama and in Florida.

In commercial citrus tree records the yield of the individual trees in weight or number of boxes of fruit are recorded by the foreman of the picking crew or some other person at the time of picking, as shown in Plate 39. Notes are made as to the production of any striking variations observed in the fruits or the trees. In the investigational record work it was found that there is a definite correla- 
tion of the amount of yield and the commercial quality of the fruits, the highest yielding trees usually producing the highest proportion of first-grade fruits of the most desirable commercial size. From the commercial records of individual tree production for a reasonable period, a classification of the trees with regard to their value for cultivation can be made, the undesirable trees top-worked or replanted, trees located for individual care and attention as needed, superior trees, if any be found, located as sources of bud-wood for propagation; and the results of tree treatments definitely determined.

\section{The Commercial Utilization of Individual Plant Recordo.}

The commercial plant records may be utilized in the origination of new varieties, the isolation of valuable strains, and in the amelioration of strains and varieties. The manner in which this utilization is effected in the citrus industry in California will be briefly described $(60)$.

The California Fruit Growers' Exchange, a cooperative non-profit organization of more than ten thousand citrus growers, established in May, 1917, a bud department of the Fruit Growers' Supply Company, which is a subsidiary organization furnishing materials and orchard supplies of all kinds to the members of the Exchange at cost. The bud department was established for the purpose of carrying out commercially the results of the investigational individual tree performance record work in the citrus fruits. In order to make this service available to the citrus industry as a whole it was provided by the Exclange that the bud department should supply reliable buds secured from superior parent trees, selected on the basis of their performance records, to all persons desiring them, whether they were members of the Exchange or not. In this way the work of the bud department is a public service. Within three years since the founding of the bud department it has furnished more than a million selected buds to propagators at a cost of five cents each to members of the Exchange, and for six cents each to non-members. The buds have been chiefly used by nurserymen in the propagation of nursery trees and to a less extent by growers for top-working undesirable trees in established and hearing orchards. The buds have been secured, for the most part, from superior parent trees found in the best citrus orchards existing in California. The parent trees have been selected as sources of bud-wood from a study of the commercial individual tree performance records in these orchards and in some instances from the best trees in the investigational performance record plats previously studied by the writer. This bud department has been a success and self-sustaining from its begiming. The young trees in the orchards grown from these buds and others selected and distributed by the writer during preceling years have prodtced earlier and more uniformly good crops of fruit than trees in comparative orchards which were propagated in the ordinary way. The value of this improved production, due to bud selection at this time, has been estimated by Mr. G. H. Powell, general manager of the California Fruit Growers' Exchange, to amount to more than one million dollars annually. In connection with the work of securing and distributing selected citrus buds, the bud department maintains an experimental 
citrus nursery for the study of problems in budding, stocks, and other phases of propagation. It also furnishes to growers reliable information as to the adaptation of citrus varieties to local soil and climatic conditions, accurate data as to the production of the varieties and the relation of this production to market conditions, and other information of value to the prospective planter or the established grower.

Potato growers in Maine, California, and in several other States have organized successful cooperative associations for the purpose of making available commercially the results of bud selection work in potato varieties.

Other associations of growers or propagators in industries founded upon varieties of plants originated as mutations are in operation at this time. Amongst these may be mentioned the Arizona-Egyptian Cotton Cirowers' Association, the New England Tobacco Growers' Association, and the Nurserymen's Bud Selection Association of California.

\section{The Selection of Superior Parent Plants.}

The selection of superior parent plants for propagation can be made on the basis of individual plant performance record data and the intimate linowledge of plant characteristics gained in the course of the plant performance record work.

In the citrus, the selection of superior parent trees is made after an adequate number of performance records have been secured. Only the high-rielding trees producing the best commercial fruts are considered as sources of bud-wood, If the records or other observations show the production of any markedly offtype fruits or striking variations, such trees are immediately discarded from further consideration as sources of bud-wood for propogation. Only those highyielding trees which consistently produce uniformly goorl fruits are selecter as parent trees.

\section{Progeny Tests.}

The bud-wood from each parent citrus tree is kept separate. The buds from each parent tree are used in separate blocks so identified in the nursery that the progenies can be traced back to the individual parent trees. Examples of the fine growth and early fruiting habits of such trees are shown in Plates 40 and 41. When the nursery trees are transplanted each progeny is kept separate, and wherever possible the trees of each progeny are planted in the orchard so that at any time the behavior of any progeny and its parent can be studied. In this manner, as well as through additional experimental progeny tests now under way, the transmitting power of the parent trees can be determined. In the California citrus industry the foundation has been laid for the future selection of parent trees on the basis of progeny records. It is probable that through this work the most reliable sources of propagating material will be secures that has ever been attained in any industry in the history of agriculture. In this connection it may be stated that in addition to extensive cooperative commercial progeny tests the writer and his associates are keeping investigational individual 
tree-performance progeny records with $5,46+$ lemon trees, 450 orange trees, and about 500 trees of other citrus varieties. As soon as funds can be secured for this work, the number of trees where investigational records are kept will be greatly increased.

Similar investigational and commercial progeny tests to those carried on in the citrus are also being conducted with cotton, tobacco, corn, oats, wheat, flax, timothy, and varieties of other agricultural crops under different auspices in various agricultural districts of the United States.

The Hawaiian Sugar Planters' Experiment Station in 1920 made a beginning of progeny test work with selected plants of the Yellow Caledonia, H 109, D 1135, and other sugar cane varieties grown in the Hawaiian Islands. The furpose of this work is to establish and maintain reliable sources of propagating material.

\section{The Scientific Study of Bud Mutations and Bud Selection.}

The oversinadowing interest amongst scientists in the study of the phenomenon of sexual variations in plants and the behavior of seedlings grown from these variations during the past century, has resulted in the partial neglect of the expally interesting and important fiekl of the investigation of bud mutations and the characteristics of plants originating from them.

As the writer sees it, the scientific problems in this connection include a study of the extent and frequency of bud mutations in all of the agricultural varieties, an investigation of the fundamental causes of the phenomenon of bud mutation, and the development of improved methods of propagation. This investigational work should precede and lay the foundation for the commercial work. While this arrangement may apparently delay the utilization of bud selection, it may, as a matter of fact, hasten the time when economic results can be obtained. The scientific studies of bud mutations, their origin and development, will probably result in the discovery of simplified methods of bud selection and insure protection from disappointments due to operations founded upon defective plans based upon incomplete knowledge leading to premature and oftentimes erroneous conclusions. In some instances it may be found to be feasible to carry on the investigational and the commercial work simultaneously. The writer believes that such is the case in the work for the improvement of sugar cane through bud selection. As the result of an experience covering more than twenty years in both the investigational and commercial work of plant breeding, the writer wishes to emphasize the necessity for scientific studies in this connection in order to discover the underlying principles of bud mutation and bud selection as a means for establishing this work in every instance upon a sound and lasting foundation.

\section{Pioneers in Bud Mutation and Selection Work.}

It seems fitting in this paper to refer to the pioneer students of bud variation and bud selection. No attempt will be made here to mention all of the men who have been concerned in this activity. These names include Carrière, Darwin, 
De Vries, Cramer, Babcock, Bailey, Castle, Collins, Cook, Dorsey, Galloway, Kearney, Shull, Stout, Swingle, and Webber. Of the men who have been more particularly concerned in the introduction and development of commercial bud selection work, the following names may be mentioned: Powell, Burbank, Fraser, Chase, Winberg, Farmer, Coates, and Milliken. To this list many other names of important workers might be added, but the writer considers that sufficient names have been given to indicate the type of workers concerned in this work.

SIMMMIRT:

The fundamental factors in the economic work for the improvement of plants through bud selection are (1) the development of new and important varieties originating from bud mutations; (2) the isolation of valuable strains of established varieties originating as bud variations; and (3) the amelioration of the cultivated varieties and strains by bringing up their average production to as nearly that of the best individuals in them as may prove to be possible through the systematic selection and propagation of superior parent plants.

The experience and achievements to date in both the investigational and commercial work for the improvement of plants through bud selection, warrant the belief that much greater progress along these lines may be expected in the future than has been accomplished in the past, when the possibilities of this work become more generally recognized and more fully understood.

The writer believes that in the plants with which he is familiar, asexual and sexual reproduction are fundamentally alike in respect to the extent and range of variation, and that equally valuable results have been achieved and may be expected in the way of plant improvement from bud selection as has been the case with seed selection. 


\section{LITERATURE CITED}

(1) Baliou, F. H. 1909, Report of the Division of Horticultural Inspection. Ohio Agr. Exp. Sta. Cire. 94.

( こ) Ballou, F. H. 1917. Letters to C. S. Pomeroy, U. S. Dept. Agr.

(3) Batrson, Wildray, 1902. Mendel's Principles of Heredity.

(4) Beach, S. A. 1905. The Apples of New York. N. Y. Agr. Exp. Sta. Rept. 1903, Part 2,

(5) Beatty, F. E. 1905. Improving Strawberries by Selection. In Proc. 2nd meeting Am. Breed. Asso., Feb., Rept. v. I, pp. 107-108.

(i) Boshnakian, Sakkis. 1916. Breeling Nephrolepis Ferns. Jour. Hered. Y. 7 , no. 5, pp. 225-236, figs. 18-25.

(7) Carmvell, J. 1874. Sports in Sugar Cane (in Mauritius), Gardeners Chron., p. 316.

( S ) Carrìne, E. A. 1865. Production et Fixation des Varietes dans les Vegetaux. Paris, Illus.

(7) Castle, W. E. 1914. Pure Lines and Selection. In Jour. Hered., v. 5, no. 3, pp. 93-97. Mareh.

(10) Castle, W. E. 1917. The Role of Selection in Evolution. In Jour. Wash, Acad, Sei., v. 7 , no. 12, pp. 369-387. June 19.

(11) Codtes, Leonard. 1920. Prunes. In Catalog, Coates Nursery Co., Ine, Morganhill, Calif., pp. 12-13.

(13) Craner, P. J. S. 1907. Kritisebe Uebersieht der bekannten Fälle von Knospenvaria-

(12) Conjor, O. W. 1915. Connor Prolifie Grapefruit. In Catalog Ocklawaha Nurseries, 1916. Tangerine, Fla., pp. 34-35. Illus.

(1:i) CRAMER, P. J. S. 190 $\overline{\text {. }}$ Kritische Uebersicht der bekannten Fälle von Knospenvariation.

(14) Darwin, Charles, 1859. The Origin of Species by Means of Natural Selection.

(15) DarwiN, Charles... 1868. The Variation of Animals and Plants under Domestication. (2nd edition, N. Y., 1900, 2 vols.)

(16) DeErR, Noel. 1911. Cane Sugar. London. Illus.

(17) Dorsett, P. H.; Shamel, A. D., AND Popenoe, Wilson. 1917. Origin and History of the Navel Orange of Bahia. In The Navel Orange of Brazil with Notes on Some Little Known Brazilian Fruits, U. S. Dept, Agr. Bul. 445, pp. 1-3.

(18) Dorsey, M. J. 1917. The Inheritance and Permanence of Clonal Varieties. In Proc, 13th Ann, Meeting Am. Soc. Hort. Sei., N. Y., pp. 41-71. Dee., 1916.

(19) East, E. M. 1910. The Transmission of Variations in the Potato in Asexual Reproduetion. Conn. Agr. Exp. Sta. Rept. 1909-10, pp. 119-160, pl. 5.

(20) Axd Haxes, H. K, 1911. Inheritance in Maize. Conn. Agr. Exp. Sta. Bul. $16 \%, 112$ p., 35 fig.

(21) Emerson, R. A. 1913. The Inheritance of a Recurring Somatic Variation in Variegated Ears of Maize. At Am. Soc. Naturalists, Cleveland, O., Jan, 1913. In Am. Nat., v. 48, no, 566, pp. 87-115, fig. 3. Feb., 1914.

(2.2) Farmer, L. J. 1911. Fall Bearing Strawberries, In Farmer on the Stramberry, Pulaski, N. Y., pp. 6i-68.

(2:3) Farmer, L. J. 1918. The Oswego Apple. In Spring and Fall Special Price List, p. 14.

(24) Fretcher, S. W. 1910. Mich. Agr. Exp. Sta., Spec. Bul. 44; Chesebro Spy Apple, p. 11; Davidson Peach, p. 35; King Grape, p. 68.

(25) Gersdorff, Chas. E. F. 1919. A Partial List of Roses Introduced in America. In The Am. Rose Ann,, pp, 134-147.

(20i) Gilbert, A. W. 1917. The Potato. New York,

(27) Griffitis, DAvid. 1913. Behavior, under Cultural Conditions, of Species of Cacti Known as Opuntia. U. S. Dept. Agr. Bul. 31, 24 p., 1 fig., 8 pl.

(4) Hedrick, U. P. 1915. Remarkable Sports of the Twenty-Ounce Apple. The Rural New Yorker, ז. 74, no. 4307, p. 722. May 22. 
(29) Kenrney, T. H. 1910, Breeding New Types of Egyptian Cotton. U. S. Dept. Agr., Bur. Plant Indus. Bul, 200.

(30) Kearney, T. H. 1914. Mutation in Egyptian Cotton. Jour. Agr. Researeh, v. 2, no. 4, pp. 287-302, pl. 17-25. July 15.

(31) Kearney, T. H. 1918. A Plant Industry Based Upon Mfutation. Jour. Hered., v. 9, no. 2, pp. 51-61, figs. 1-8. Feb.

(32) Kellog, R. II. 1902. Bud Variation in the Strawberry Plant. Inter. Conf. Plant. Breed, and Hybrid,, N. Y. In Rept. N. Y. Hort. Soc., v. 1

(33) Le Lovg, B. M. 1891. The Pierce Grape. In Calif. State Board Hort. Rept., 1891, pp. 131-132, 1 col. pl.

(34) MEad, H. O. 1916. A Red Gravenstein Apple. In The Rural New Yorker. March 4.

(3.5) Morris, D. 1901. Bud Tariation in the Sugar Cane. In West Indian Bul., v. :, no. 3 , pp. 216-223, 2 col. pl.

(36) Mryers, C. H. 1914. Improving the Potato Crop by Selection. Cornell Reading Courses, v. 3, no. 68, pp. 229-248, figs. 121-133. July 15.

(3i) Paddock, W. 1896. But Variation of the Concord Grape. In Gard. and For., v. 9, p. 464 . Nov, 18 .

(39) Pierson. Wallace R. 1918. Rose Families and Their Tendencies. In The Am, Rose Ann., pp. 99-100.

(39) Pomeroy, C. S. 1919. Bud Variations in Sugar Cane. Jour. of Hered., v. 10, no. 3, pp. 129-135, figs. 16-17. March.

(40) Powell, G. Harold, 1898. Plant Breeding: Its Application Through Bud Selection to the Improvement of Varieties. In Amer. Garl., v. 19, pp. 466-467, 514-515. July 14.

(41) Powell, G. T. 1902. Bud Variation in the Apple. Inter. Conf. Plant, Breed. and Hybrid., N. Y. In Rept. N. Y. Hort. Soc., v 1.

(42) Powell, G. T. 1909. $\$ 1000$ an Acre from Pedigreed Trees. In Country Life in Am., v. 13, no. 5, pp. 501-6, 538, 540. Illus.

(43) Poweld, G. T. 1916. Transmitting Productive Qualities in Fruit Trees Through Bud Selection, West. N. Y. Hort. Soe. (Rochester).

(44) Powell, G. T. 1920. Thirty Years' Experience in Application of Bud Selection in the Fruit Industry. Asso. Calif. Nurserymen, San Francisco, In Calif. Citrograph, r. 5, no. 11, pp. 34t, 36t-6. Illus. Sept.

(4.) Reasoner Bros. 1914. Foster Grapefruit. In Catalog Royal Palm Nurseries, 1915, Oneco, Fla., p. 11, 2 illus. ( 1 eol.).

(40) Roenixg, Geo. C. 1919. Euonymus, In Catalog Fancher Creek Nurseries, Fresno, Calif., p. 15.

(4i) Shames, A. D. 1907. New Tobaceo Varieties. In U. S. Dept. Agr. Yearbook 1906, pp. 387-404, figs. 11-14, pl. 33-36.

(45) Shamel, A, D, 1911. A Study of Bud Selection in Citrus Fruits. In Proe. 39th Calif. Fruit. Gr. Conv., pp. 89-105. Nareh 8.

(f!!) Shamel, A. D. 1911. A Study of the Improvement of Citrus Fruits Through Bucl Selection. U. S. Dept. Agr., Bur. Plant Inclus. Cire. 77, 19 p., 5 fig. June 2.

(jii) Shamel, A. D. 1917. A Humilifier for Lemon Curing Rooms. U. S. Dept. Agr. Bul. 494, 10 p., 7 fig. Jan.

(.i1) SHadel, A. D. 1917. Citrus Fruit Improvement: How to Seeure and Use TreePerformance Recoris. U. S. Dept. Agr., Farmers' Bul. 794, 16 p., 4 fig. Feb.

(i2) Shamer, A. D. 1917. A But Variation of Pittospormm. In Jour. Hered., v. \&, no. S, pp. 357-358, fig. 1. August.

(53) Shamer, A. D. 1918. A Method of Feeding Manure to Orange Trees. In Calif. Citrograph, v. 3, no. 6, pp. 124-125, 4 fig. April.

(it) Shamed, A. D. 1918. Can California Proluce Good Grapefruit. At Calif. Grapefruit Club, March 20. In Calif. Citrograph, v. 3, no. 7 , pp. 153, 163, 2 fig. May. 
(55) Sramel, A. D. 1919. Some Results from an Experiment with Pruning as Compared with No Pruning of Full-Bearing Washington Navel Trees. In Calif. Citrograph, v. 4 , no. 7 , pr. 174-175, 3 fig. May.

(56) Shamel, A. D. 1919. Applying the Furrow Manure in Citrus Groves. In Calif. Citrograph, v. 5 , no. 1, p. 4, 4 fig. Nov.

(57) Shamel, A. D. 1919. Origin of a New and Improved French Prune. In Jour. Hered., v. 10, no. 8, PI. 338-343, fig. 1-3 and frontispiece. Nov.

(58) Smanet, A. D. 1920. Results of Five Years' Individual Tree Performance Records with Pruned and Unpruned Lemon Trees. In Calif. Citrograpl, r. 5, no, 4, pp. 102, 12:-123, 129, 3 fig. Felb.

(5y) Shamel, A. D. 1920. Control of Humidity Conditions in Lemon Storage Rooms. In Calif. Citrograph, v. 5, no. 5, PP. 137, 170-171. Mareh.

(60) Shanel. A. D. 1920. Conperative Improvement of Citrus Varieties. In U. S. Dept. Agr. Yearbook, 1919, pp. 249-275, 15 fig. (Issued as Yearbook Separate No. 813.)

(6i) SHAMEL, A. D. 1920. Origin of a Grapefruit Variety Having Pink-Coloresl Fruits. In. Jour. Hered., พ. 11, no. 4, PH. 157-160, fig. 5-8, April.

(62) SHAMEL, A. D. 1920. The Conservation and Applieation of Manures, In Calif, Citrograph, v. 5, no. 7 , p p. $213,2+0-2+3,3$ figs. Hay.

(63) SuAmel, A. D. 1920. Results of Individual Tree Performanee Stulies With Pruned and Unpruned Marsh Grapefruit Trees, In Calif. Citrograph, v. 5, no, 8, pp. 215, $265-269,4$ fig. June.

(64) - ScotT, L. B., AND Pomeror, C. S. 1918. Citrus Fruit Improvement: A Stuly of Bud Variation in the Washington Navel Orange. U. S. Dept. Agr. Bul. $623,146 \mathrm{p} ., 16 \mathrm{fig}, 19 \mathrm{pl}$. _ ScotT, L. B, AND Poneroy, C. S. 1918. Citrus Fruit Improvement: A Study of Bud Variation in the Valeneia Orange. U. S. Dept. Agr. Bul. 624, 120 p., y fig., $1+$ pl.

— ScotT, L. B., AND Pomeror, C. S. 1918. Citrus Fruit Improvement: A Stuly of Bud Variation in the Marsh Grapefruit. U. S. Dept. Agr. Bul, 697, 112 p., $1+\mathrm{fig}, 11 \mathrm{pl}$. ment: A Stuly of Bud Variation in the Eureka Lemon. U. S. Dept. Agr. Bul. 813, 88 p., 22 fig., 7 pl.

ment: A Stuly of Bul Variation in the Lisbon Lemon. U. S. Dept. Agr. Bul. S15, 70 p., 14 fig., 8 pl.

(i!) Stout, A. B. 1915. The Origin of Dwarf Plants as Shown in a Sport of Hibiseus aculiroseus. Bul. Torr. Bot. Cluh, x. 42, pp. 429-450, pl. 26-27. Sept. 22.

(ii) Stout, A. B. 1915. The Establishment of Varieties in Coleus by the Selection of Somatie Variations, Carnegie Inst. Wash. Pub. 218,80 p., 4 pl, (3 col.). Oet. 7.

(i1) TotTy, Charles H. 1918. Ophelia ani Its Progeny. In The Am. Rose Ann., pp. 96-95.

(ï) DE Vries, Hugo, 1901-3. Die Mutationstheorie, 2 v., illus. Leipzig. (Eng. trans. 1909-1910. Chicago.)

(73) DE VRIES, Hugo, 1905. Species and Varieties; Their Origin by Mutation. Chicago.

(74) De Vries, Hugo. 1918. Mass Mutation in Zea mays. In Seience, n.s., Y. 47, no. 1219, PT. 465-467.

(75) WaID, C. W. 1907. Results of Hill Selcetion of Seed Potatoes. In Rept. Am. Breed. Asso., v. 3, pp. 191-198.

(ii) Webber, H. J. 1903. New Horticultural and Agrieultural Terms. In Science, n. s., v. 18, pp. 501-503.

(ii) Webber, H. J. 1909. Clonal or Bud Fariation. In Rept. Am. Breet. Asso, v. 5, Pp. $347-357$.

(i) WEBber, H. J. 1912. The Production of New and Improverl Varieties of Timothy. Cornell Univ. Agr. Exp. Sta. Bul, 313, pp. 337-392, tig. \$6-96, pl. 1-10. April. 


\section{EXPLANATION OF PLATES}

PLATE.

1. Branches of the variegated Shrubby Althea or Rose of Sharon (Hibiscus syriacus) showing solid green-leaved branches arising as bul variations. Riverside, Cal.

2. Variations in a Dahlia plant which have persisterl during the five years of the life of the plant. The normal color of the flowers is deep velvety red, and the variations are white and pinkish white. Riversile, Cal.

:. Dahlia Hower of Le Grande Manitou variety and a bud variation found on a plant of that variety. Riversicle, Cal.

4. A branch of Euonymus juponica showing the bud origin of the silver-variegated hortieultural variety argenteo-variegatus. Several, if not all, of the other sub-varieties of this plant originated as bul mutations. Riversicle, Cal.

5. Branches of Pittosporum tobiru var, variegatum, showing green-and white-leaved bud rariations. Riverside, Cal,

(i. A bush of Pittosporum tobira var. variegatum, which has several green-leaved and white-leaved branch sports. Riverside, Cal.

7. Branches of the oleander (Nerium oleander) showing (right) the normal green foliage and (left) a rariegated form foum as a branch variation in the same bush. Thermal, Cal.

భ. Winter Banana apples, showing a reul and two large fruits oceurring as limb variations. C. H. Whittum, Eaton Rapids, Mich.

9. Prunes from a single tree of a new bud strain, the Coates $1+18$. Upper right, typieal Coates 141s; lower right, typieal ordinary Freneh prume; left, four Coates $141 \mathrm{~s}$ and one ordinary French. Morgan Hill, Cal.

10. Thompson Seedless grapes, showing (left) the normal fruit and (right) a largefruited form discovered as a bud mutation and propagated by its owner. Thermal, Cal.

11. Bartlett Pears, showing (right) ordiuary strain, (center) oblong strain, and (left) sunken section oecurring as bul variatious. Tehachapi, Cal.

12. Leaves and flower buds (the edible portion) of two strains of the common artichoke (Cynara scolymus) found on neighboring plants and doubtless resulting from a bud variation. Riverside, Cal.

13. A representative tree of the Washington strain of the Washington Navel orange, bearing heavy crops of high-grade fruit. Highgreve, Cal.

14. Fruits showing variations oecurring on a single tree of the Thomson strain Wastiogton Navel orange. These variations have been propagated and each of the two progeny trees are producing fruit of the same character as their several bud parents, showing these forms to be true mutations. Highgrove, Cal.

15. Characteristic trees of the Australian (left) and Washington (riglit) strains of the Washington Navel orange. Highgrove, Cal.

16. A typical fruit of the Washington Navel orange variety am an Australian fruit found as a limb sport in the same tree. Highgrove, Cal.

17. A basket of Washington Navel oranges from a tree of the Washington strain. Rirerside, Cal.

15. Fruits of the Corrugated strain of the Washington Navel orange oceurring as a limb mutation in a tree of the standard strain. Highgrove, Cal.

19. Fruit of the Dry strain of the Washington Navel orange, oecurring as a branch mutation in a tree of the standard strain. Riversile, Cal.

20. Typieal fruit of the Marsh strain of the Marsh seelless grapefruit. Note the desirable shape, thin skin, fine texture, and seelless character. Highgrove, cal.

:1. A fruit of the Seely strain of the Marsh grapefruit. Highgrove, Cal. 
2.2. A few of the Eureka lemon types that frequently oceur as but rariations on a single tree. Corona, Cal.

23. Branches of the Variegated Eureka lemon showing the characteristic markings of fruits, leaves, and young trigs. This strain originated as a branch mutation and has been propagated through three bud generations. Corona, Cal.

24. A Navel lemon found as a bud rariation on a tree of the Eureka variety. Escondido, Cal.

25. Typieal lemons of the Lisbon strain, the type of the Lisbon rariety. Five other strains of this variety have been found as bud variations, recorded and propagated during the bud selection work of the U. S. Department of Agriculture. Corona, Cal.

21. Lishon lemons showing pronounced variations oceurring on a single tree of an inferior strain. Corona. Cal.

27. A typjeal tree of the Shale Tree strain of the Eureka lemon. The trees of this strain are vigorous and rapid in growth but low in production and bear fruits of a low grade. Corona, Cal.

34. A young Eureka lemou tree of the Eureka strain. Note the productive condition of the tree and the fine type of fruit. Corona, Cal.

29. Marsh grajefruit top-workel on an undesirable tree. Higbgrove, Cal.

:3). Ruby Blool oranges showing typical fruit and others from a branch mutation, showing various stages of iryness, the most of the fruit being entirely dry. Nearby trees hore heavy crops which were all of the Dry strain. Corona, Cal.

31. Branch from a Ruby Blood orange tree showing the oceurrence of a Navel fruit as a bud variation. In this way the Bahian Navel orange is frequently found in Brazil as bud mutations in trees of the Selecta variety. Corona, Cal.

3.. Thomson orange tree in which the entire upper part and right side are barren every season, the lower left portion bearing normally. Riversile, Cal.

33. Washington Navel orange orchards along the foothills, showing two orchards in which indivitual tree performance records were secured in the investigational work of the U. S. Department of Agriculture. Highgrove, Cal.

34. View in a Washington Navel orange orcharl showing the method of grading, sizing, meighing, and reeording the production of individual trees in the investigation performance record work of the U. S. Department of Agriculture. Highgrove, Cal.

35. Typieal flowers of the Washingion strain and the Seedy strain of the Washington Navel orange. Note the abundance of pollen protuced by the anthers of the Seetly strain, while the flowers of the Washington strain do not protuce pollen. Riversile, Cal.

36. View in an Eureka lemon tree, showing the type of fruit-bearing but-wood advised for use in propagating from select parent trees. The leaves have been eut from one twig in oriler to show its eharacteristies to better ardvantage. Corona, Cal.

3i. Citrus propagation: Cutting a but from a typical but-stick of fruit-bearing wood for insertion into the seerlling stock.

$\therefore$ C. Citrus propagation: Steps in the budding of a citrus nursery tree (from left to right): seedling stock; inverted T-shaped eut for bud; loud inserted; inserted bud wrapped with waxel cloth; butling knife. Risersisle, Cal.

39. View in a Washington Navel orange orebard, showing the method of securing commercial individual tree performance records in this 1500 -acre planting. Highgrove. Ca].

40. Two-year-old Eureka lemon nursery propagated from selecterl fruit-bearing bul-wood, showing the fine tree development and the early fruiting tendency, Redlands, Cal.

41. Eureka lemon tree, 2 years 9 months olil, propagated from select performance record trees. Note fruitful comition and fine eharacter of fruit. Claremont, Cal. 


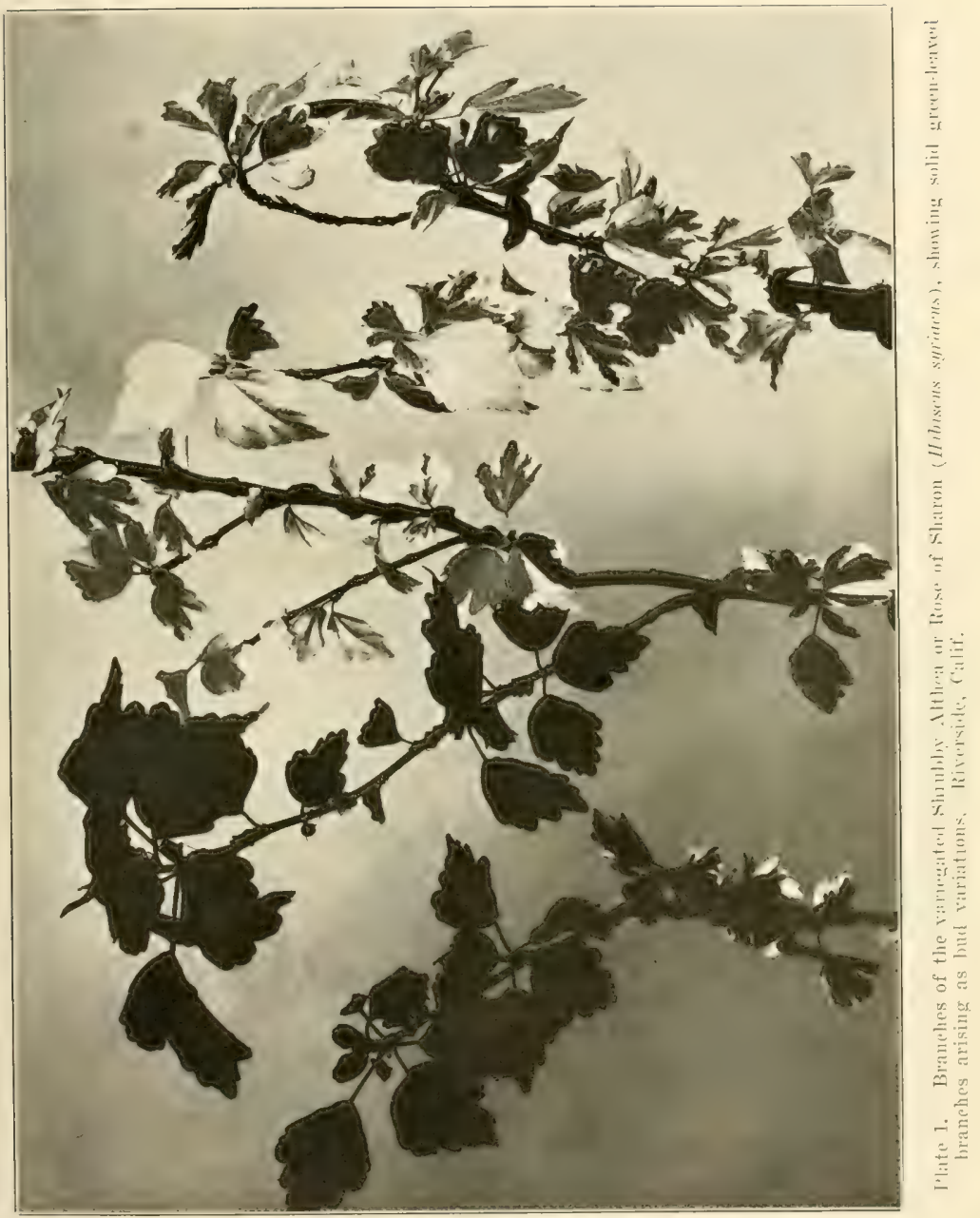




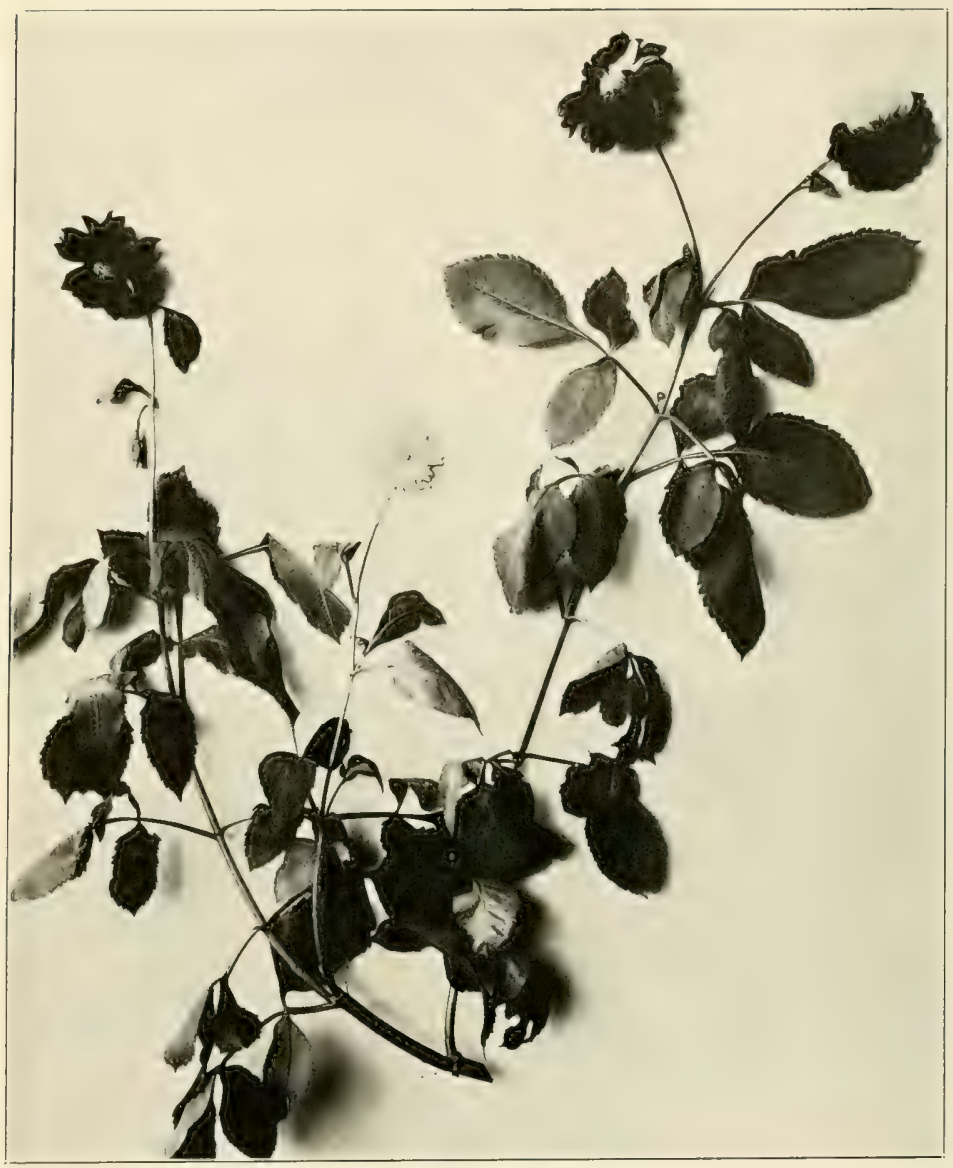

Plate 2. Tariations in a Dallia plant which have persisted luring the five years of the life of the plant. The normal color of the fowers is leep velvety red and the variations are white and pinkish white. Riverside, Calif. 


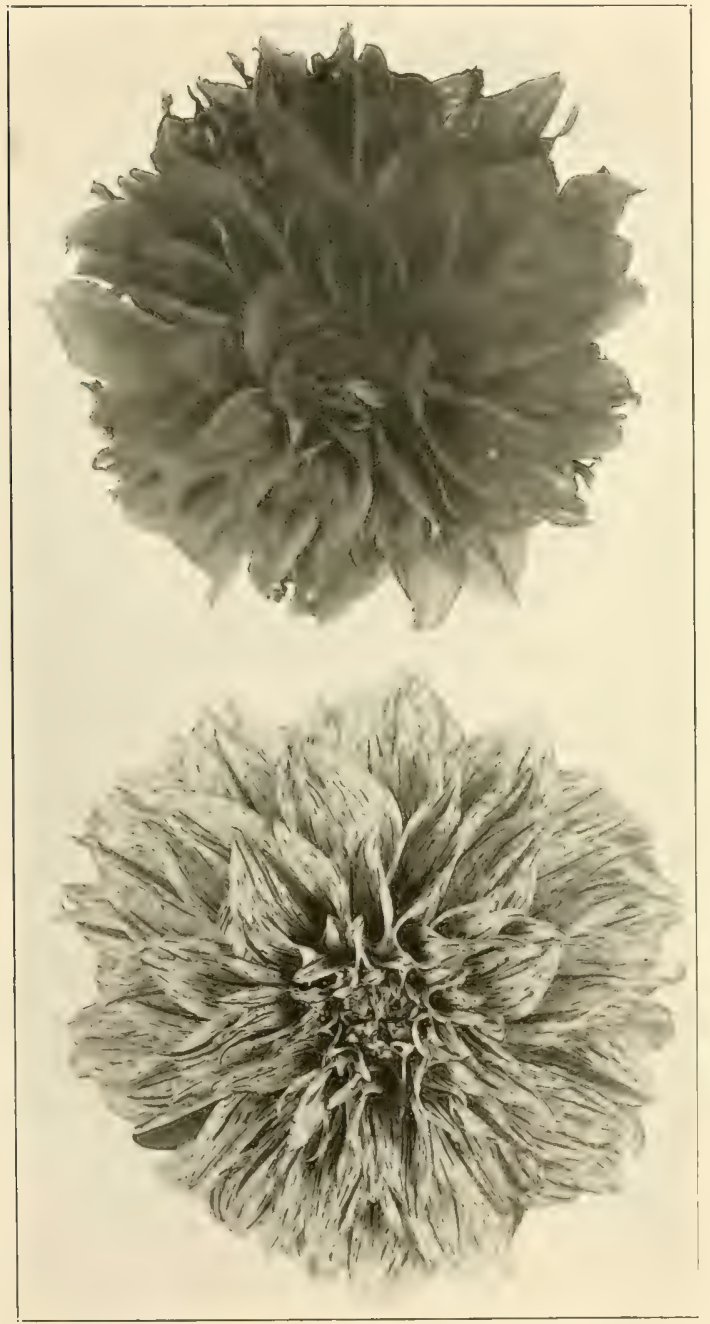

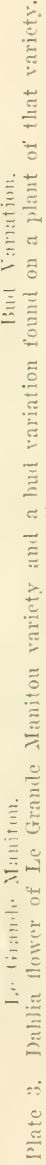




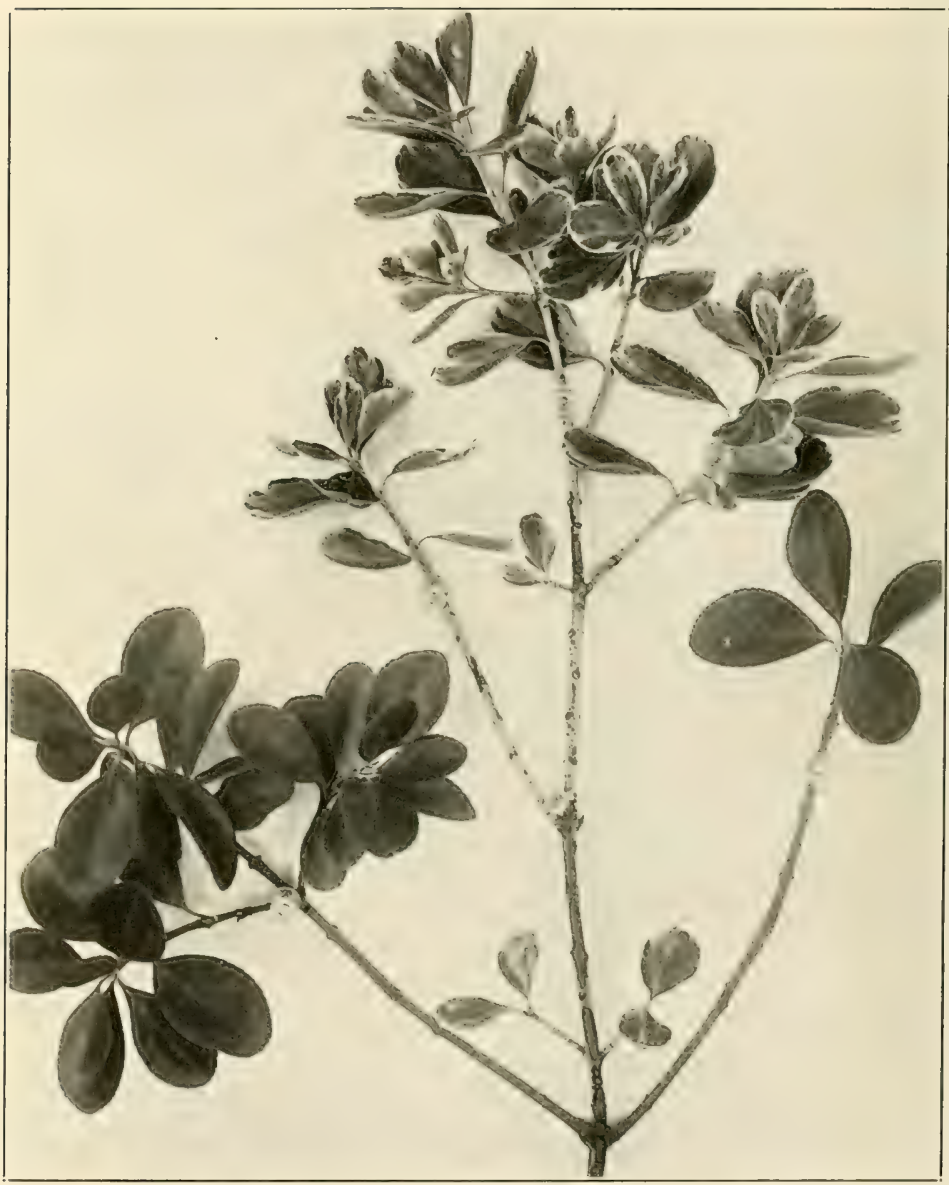

I'late 4. A branch of Euonymus japonica, showing the buil origin of the silver-variegater horticultural variety argenten-enrimatus. Several, if not all, of the other sub-varieties of this plant originated as bud mutations. Riversile, Calif. 


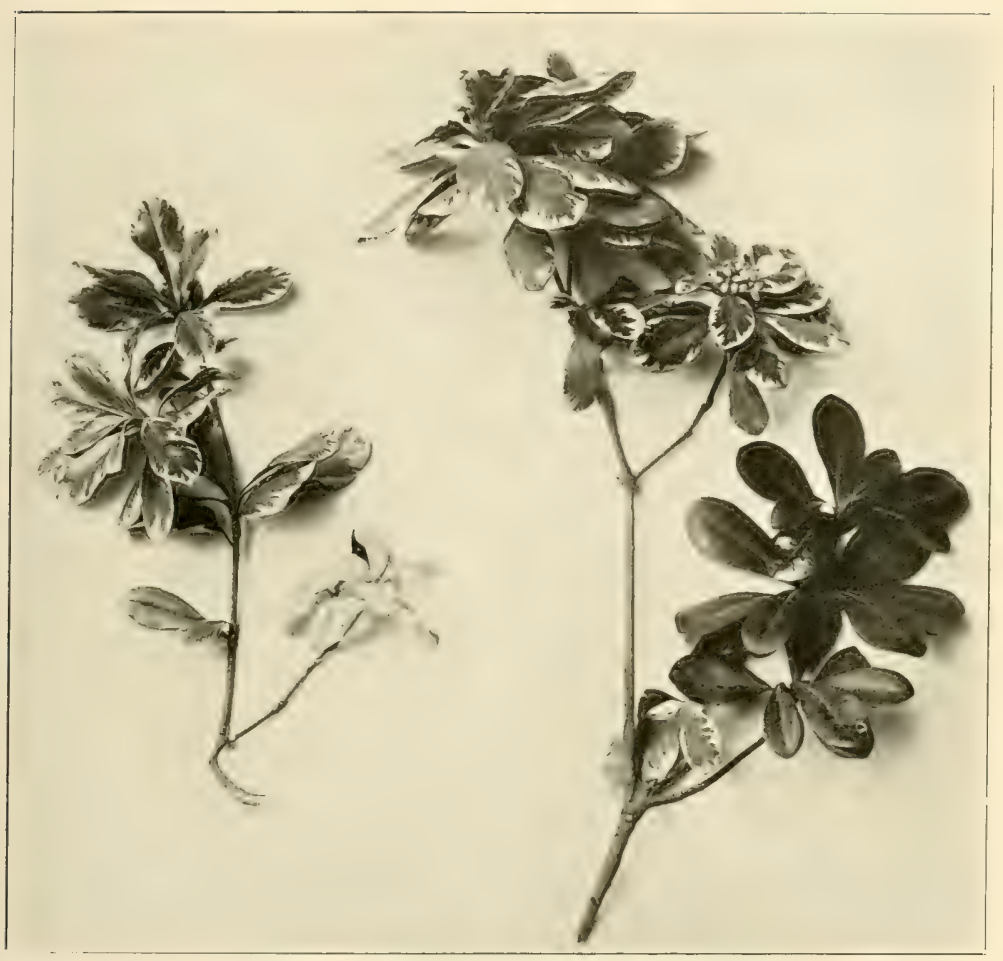

Plate 5. Branches of Pittosponm tobira var, variegutum, sbowing green- and whiteleaved bul variations. Riversile, Calif. 


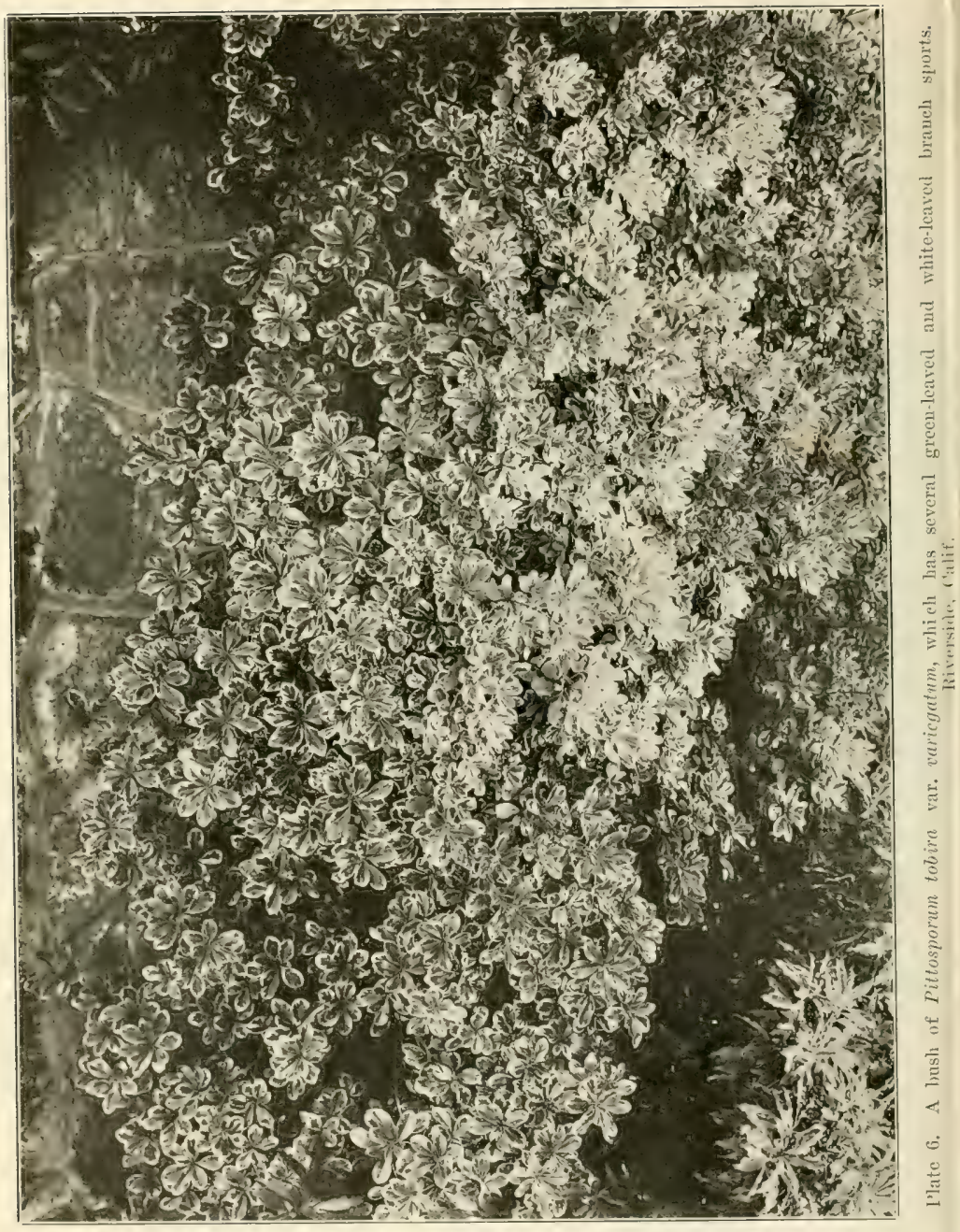




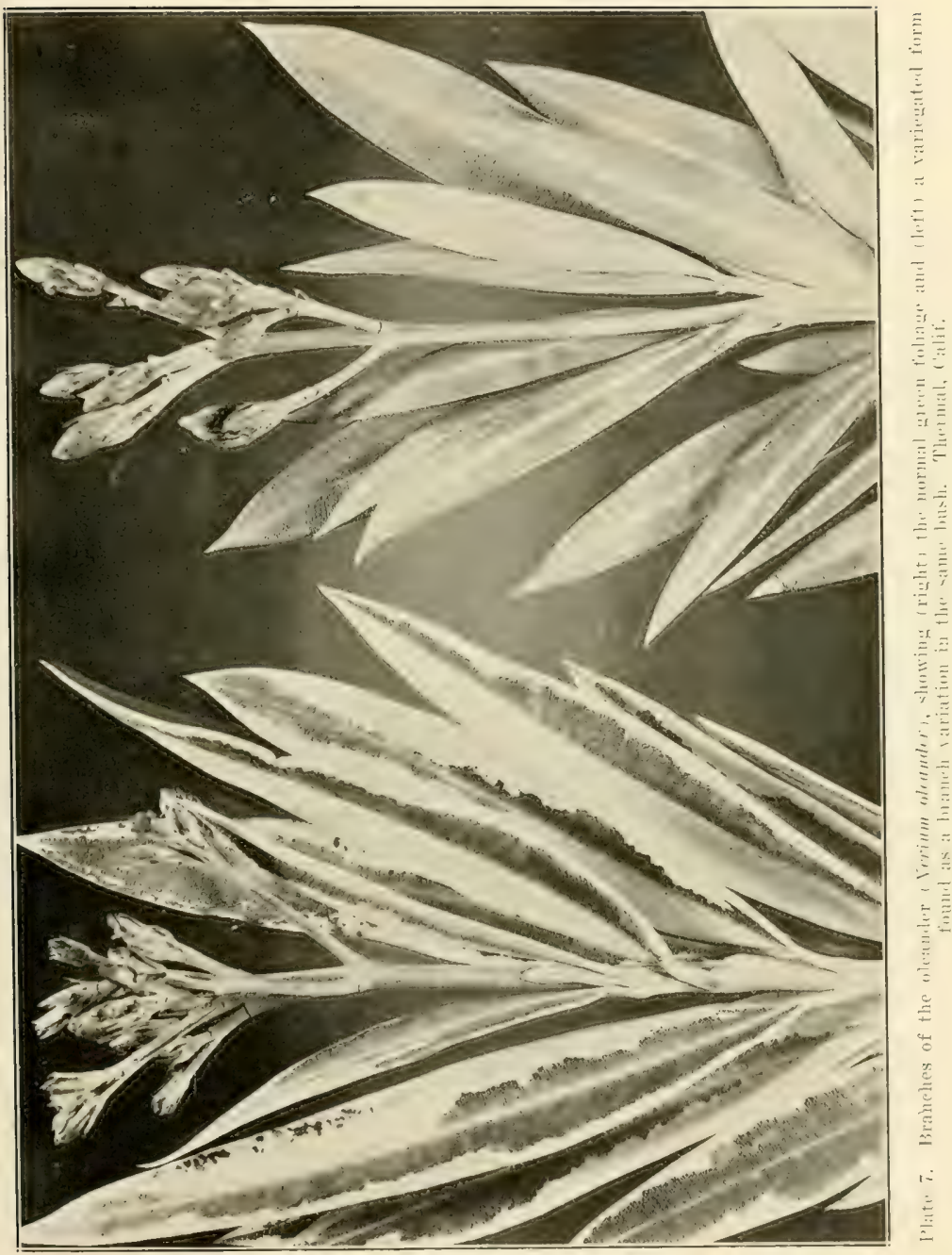




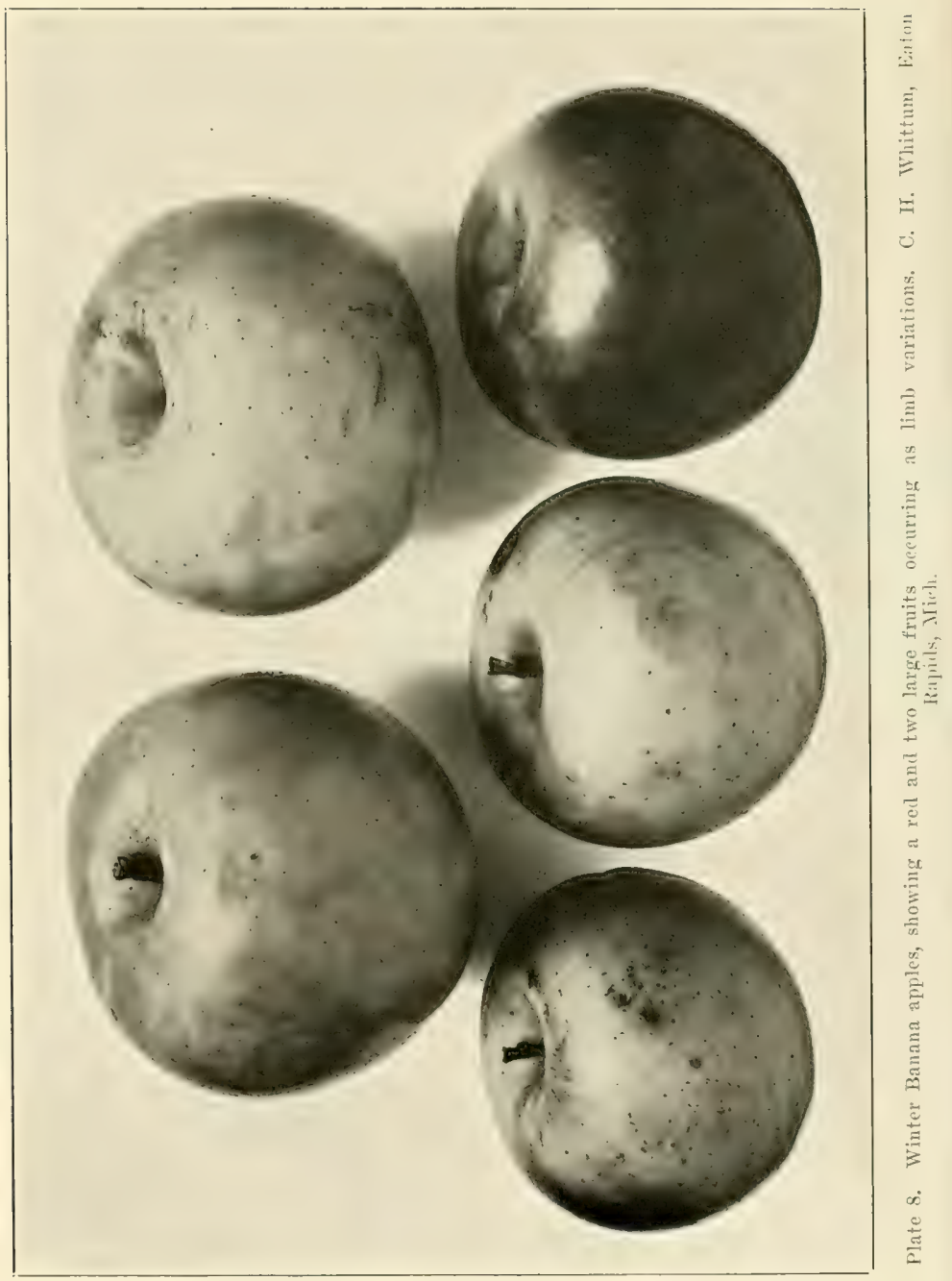




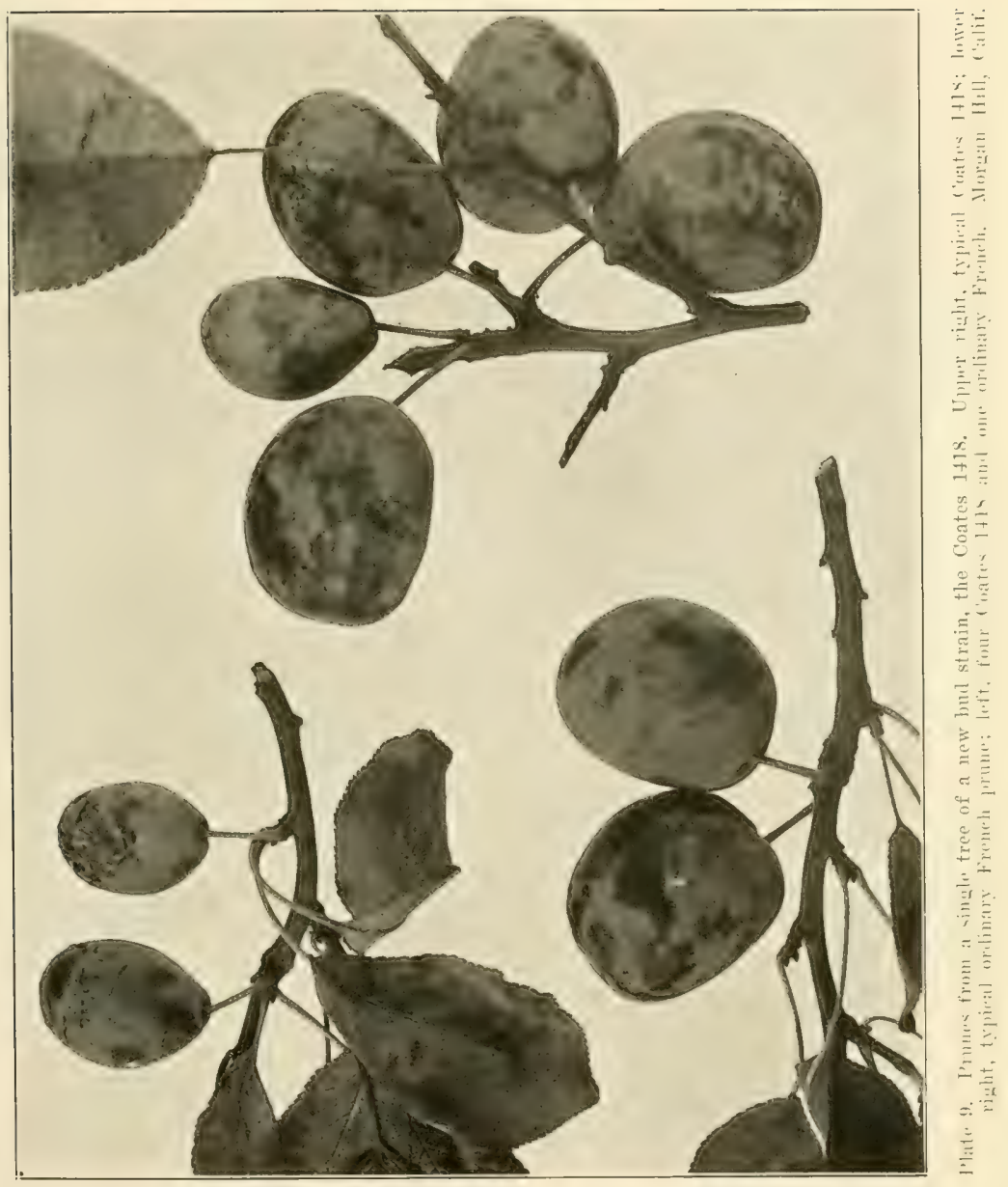




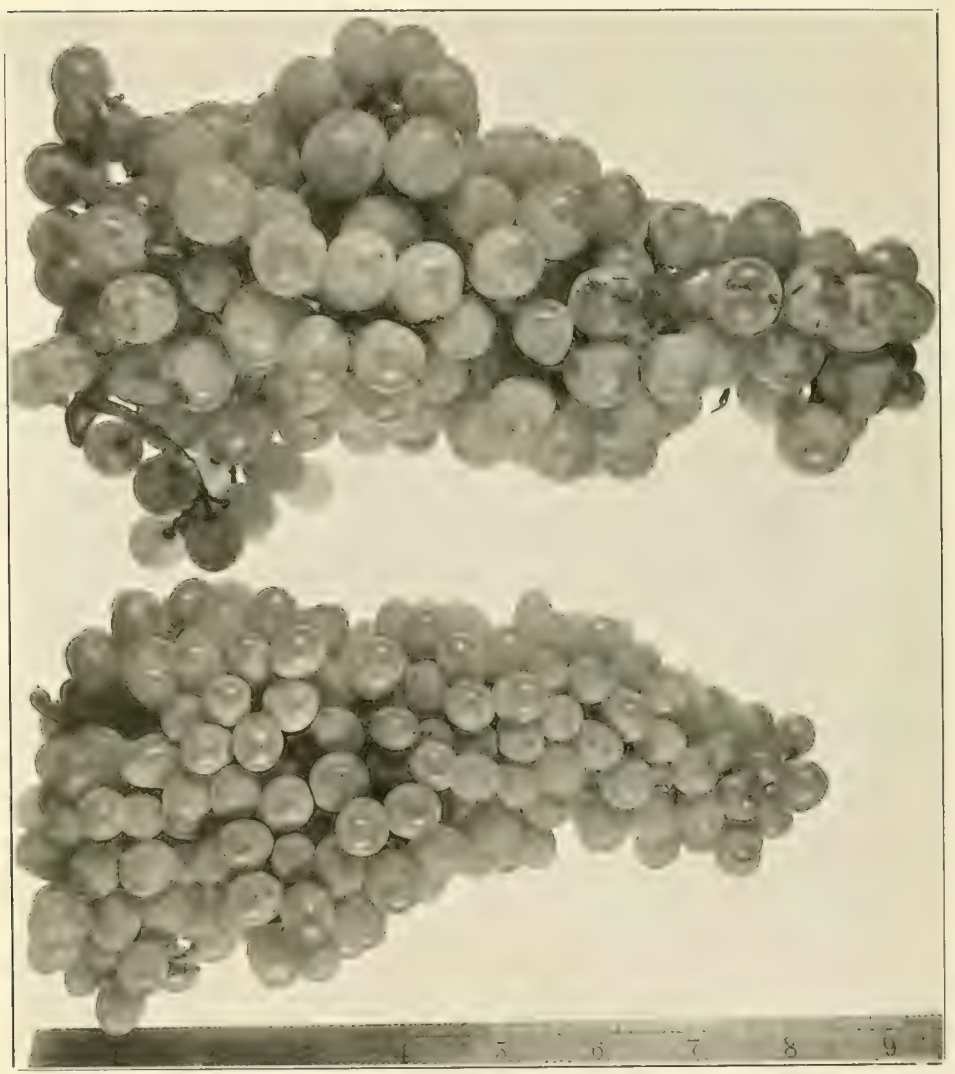

站 


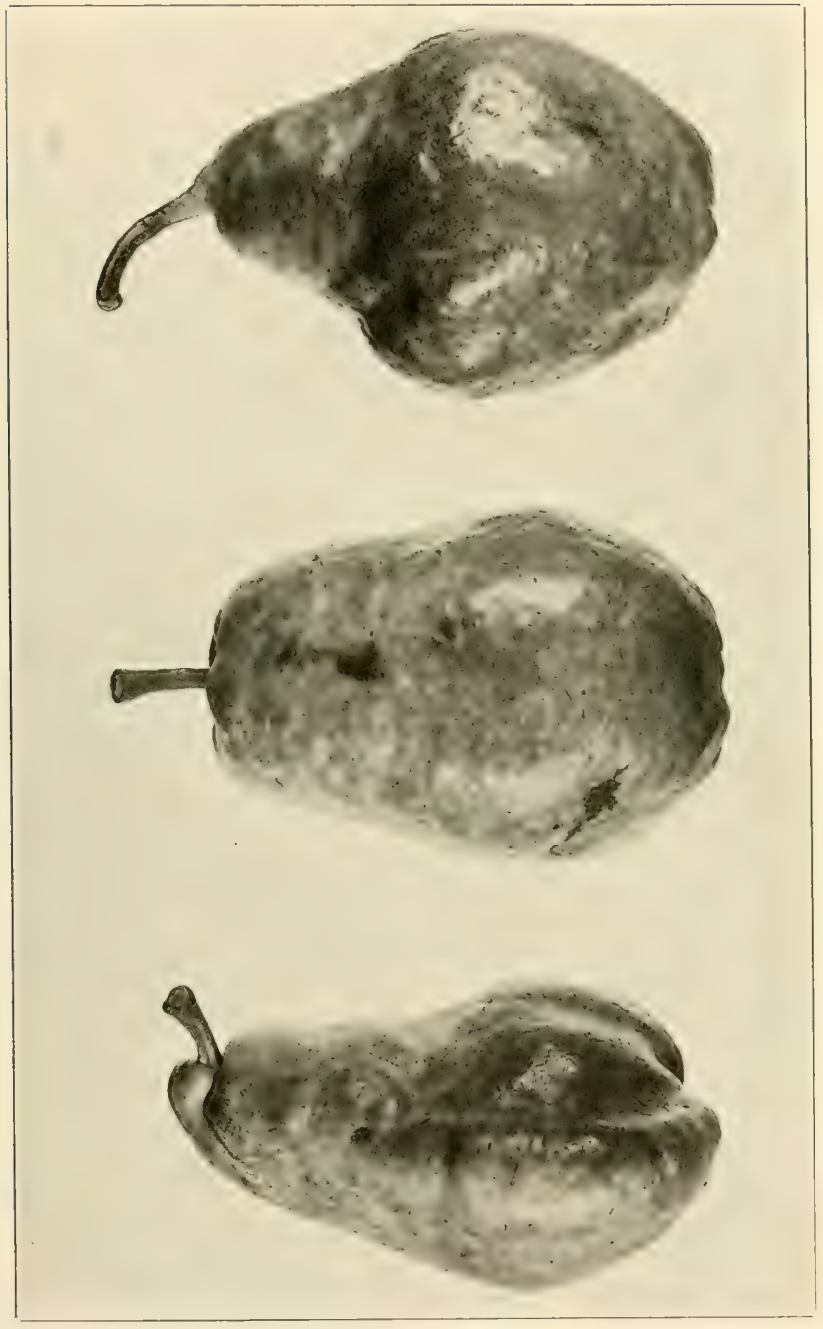

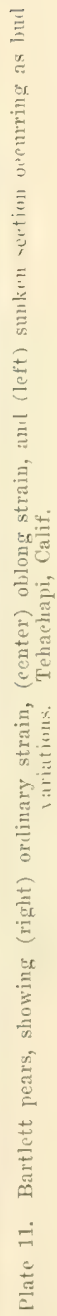




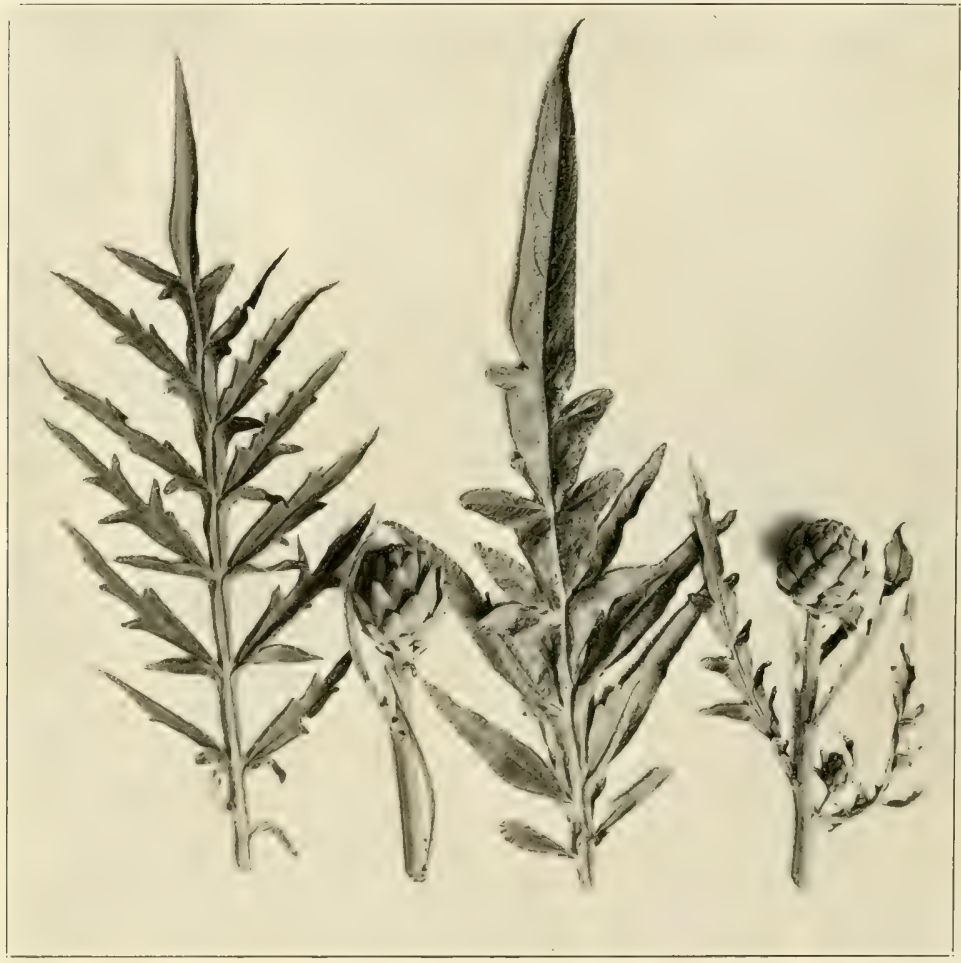

Plate 12. Leaves and Hower buls (the eqlible portion) of two strains of the common artichoke (Cynara scolymus) fouml on neighboring plants and doubtless resulting from a bud variation. Riverside, Calit. 


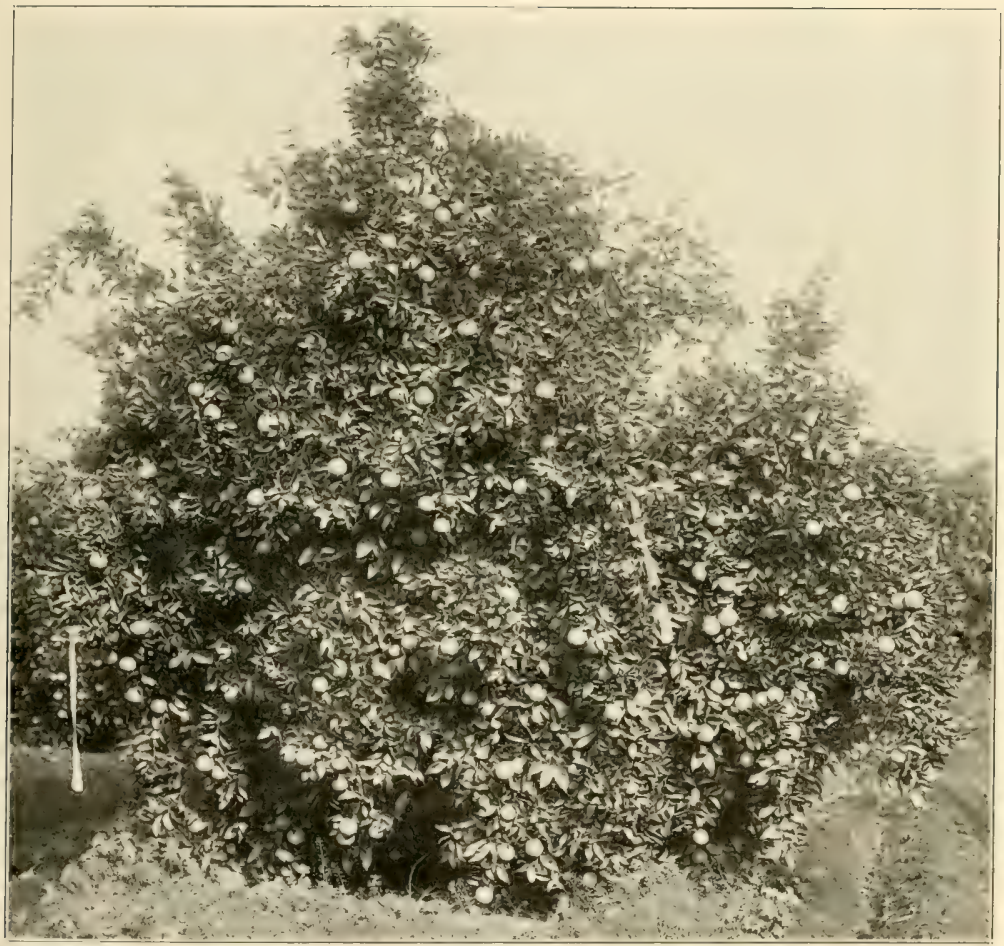

Plate 13. A representative tree of the Washington strain of the Washington Navel orange, bearing heary crops of high-grate fruit. Highgrove, Calif. 


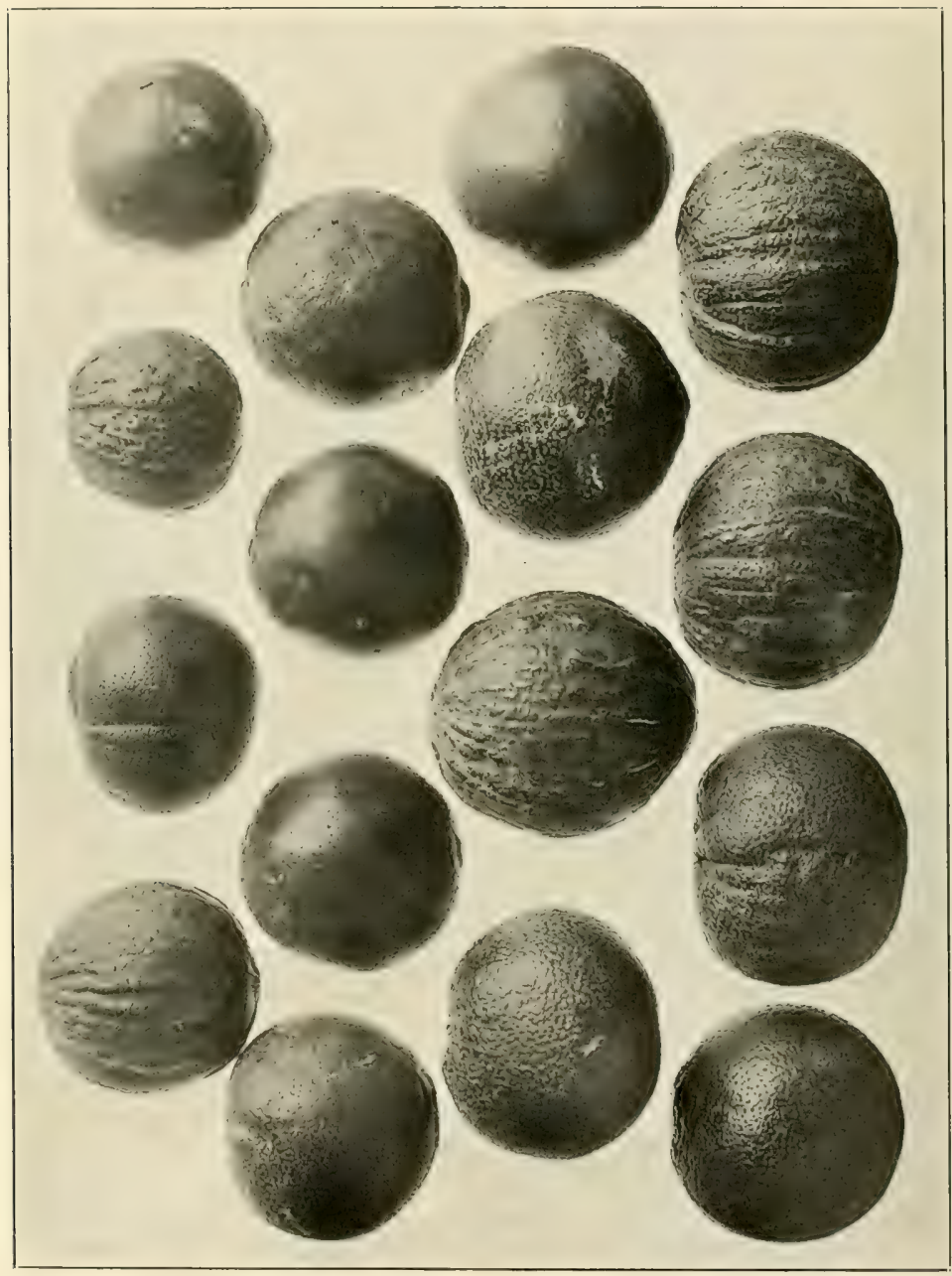

글 


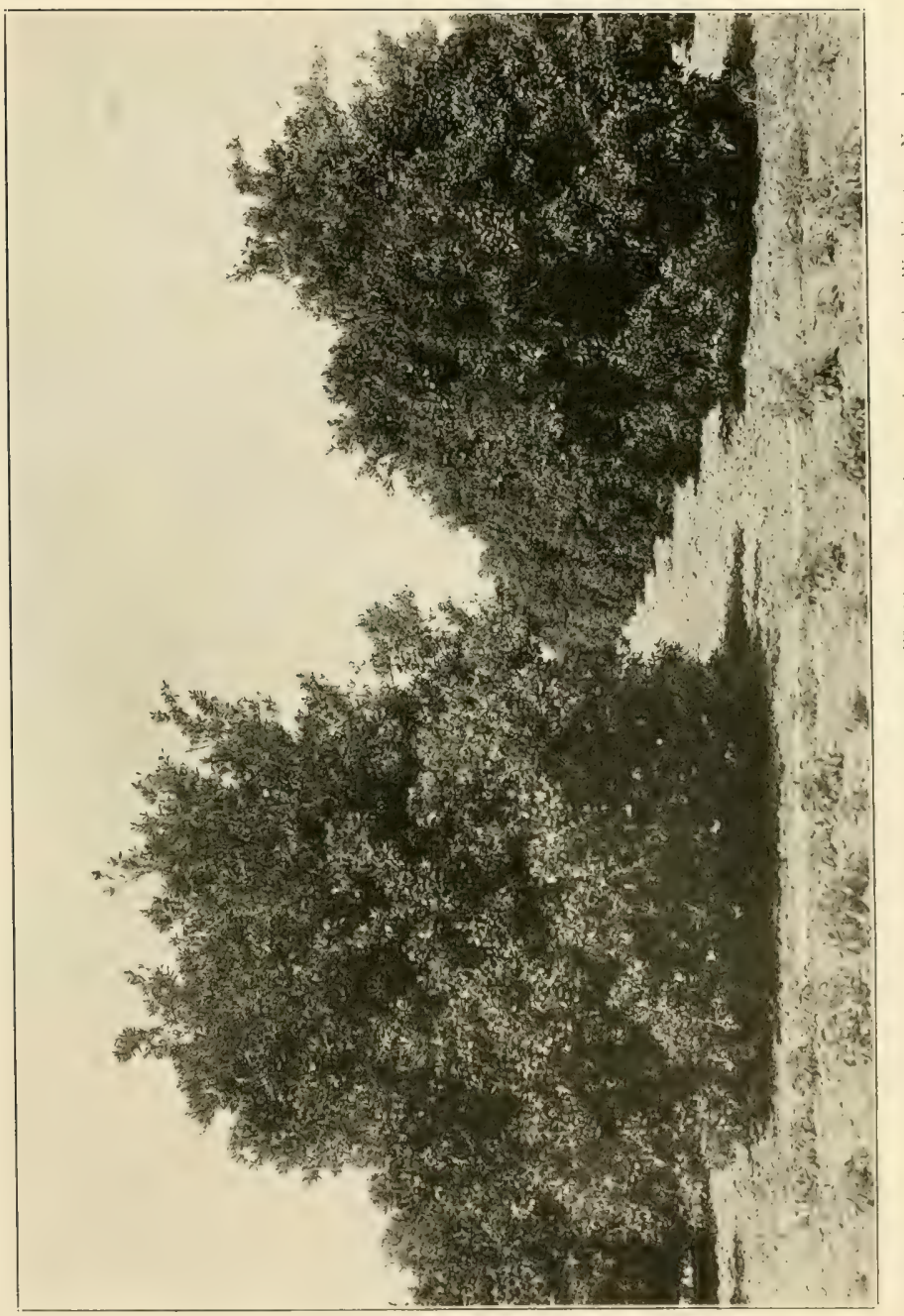

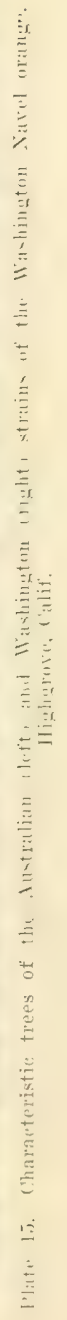




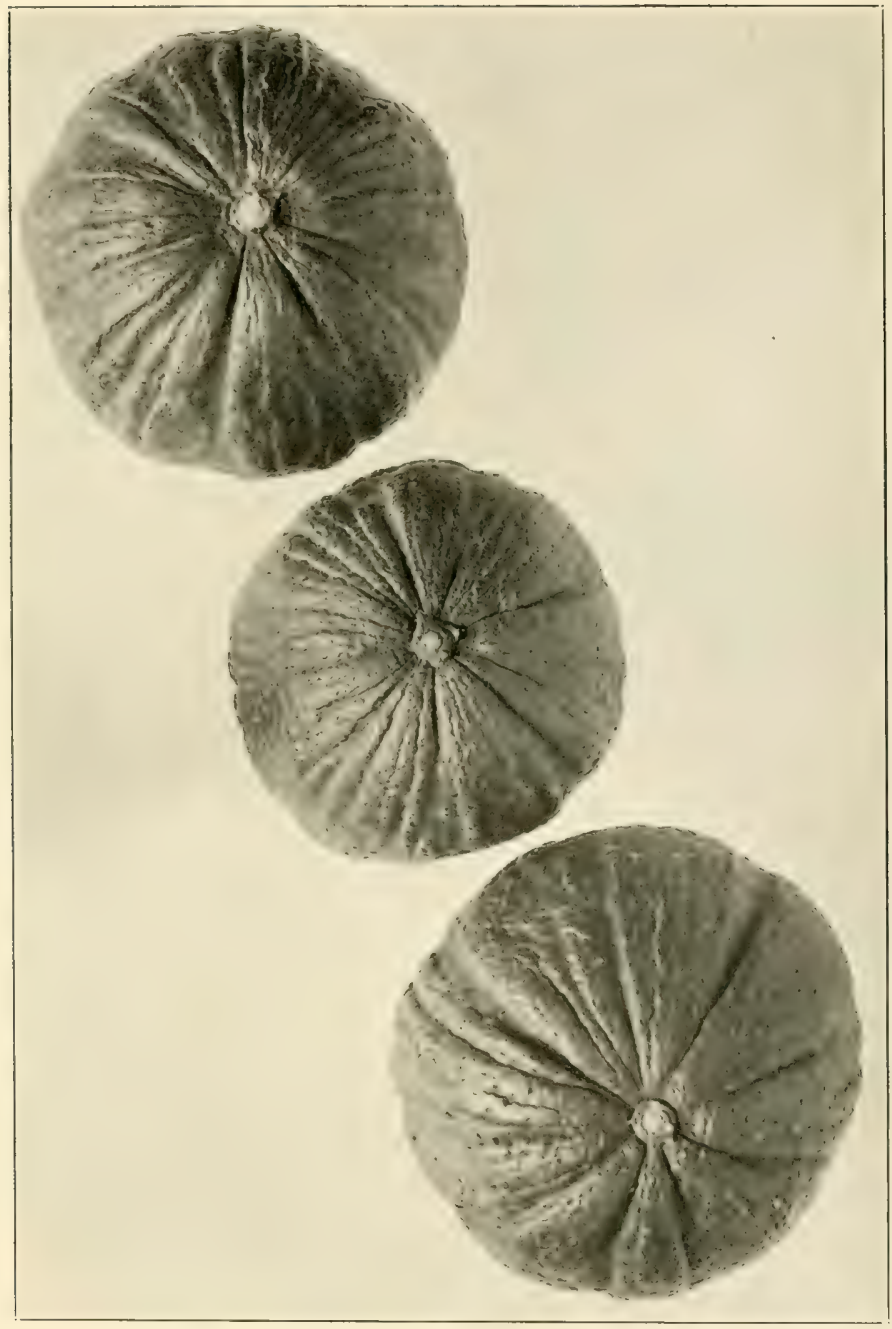

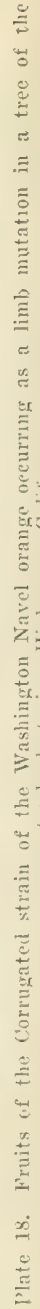




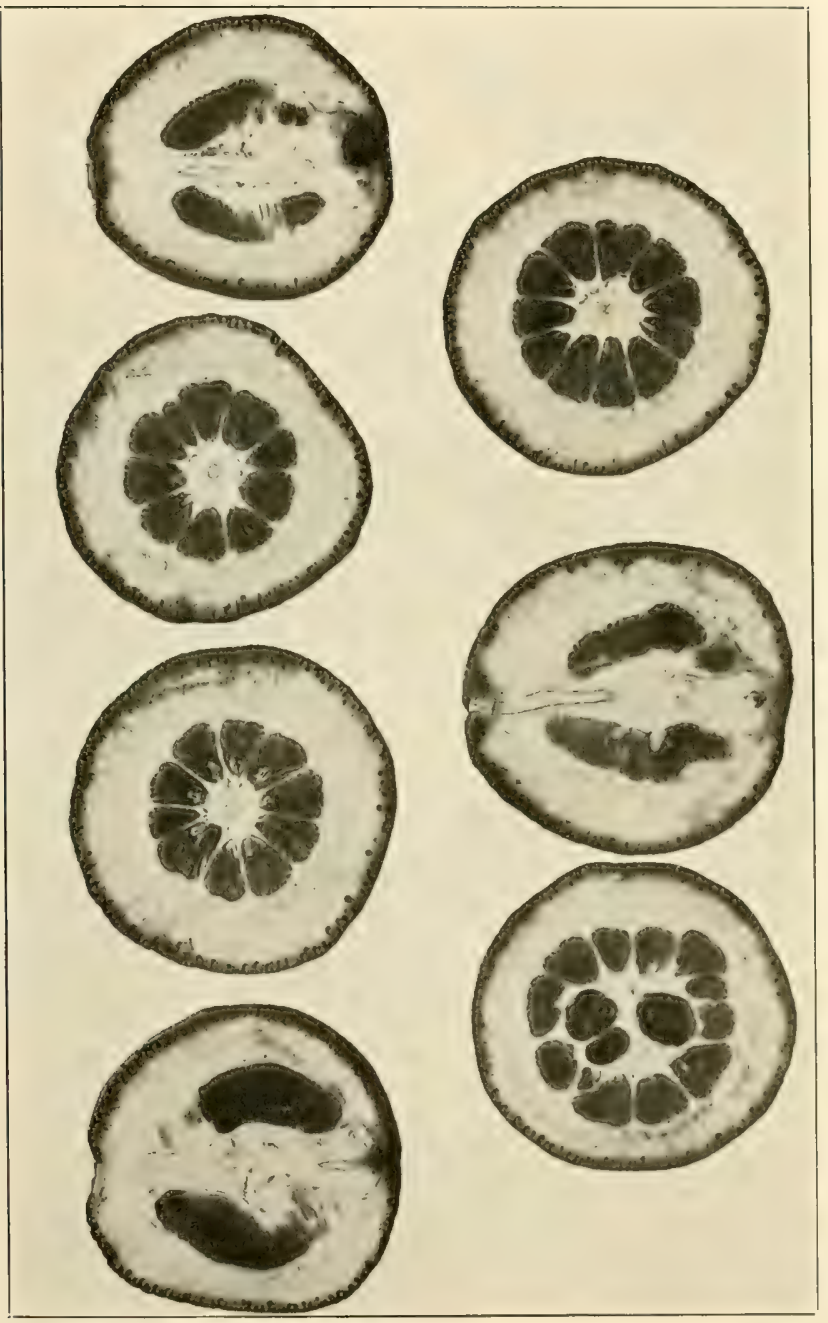

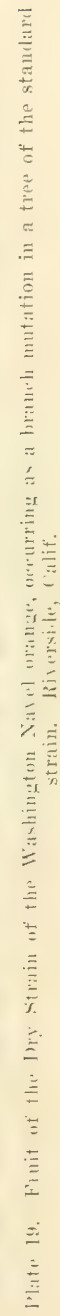




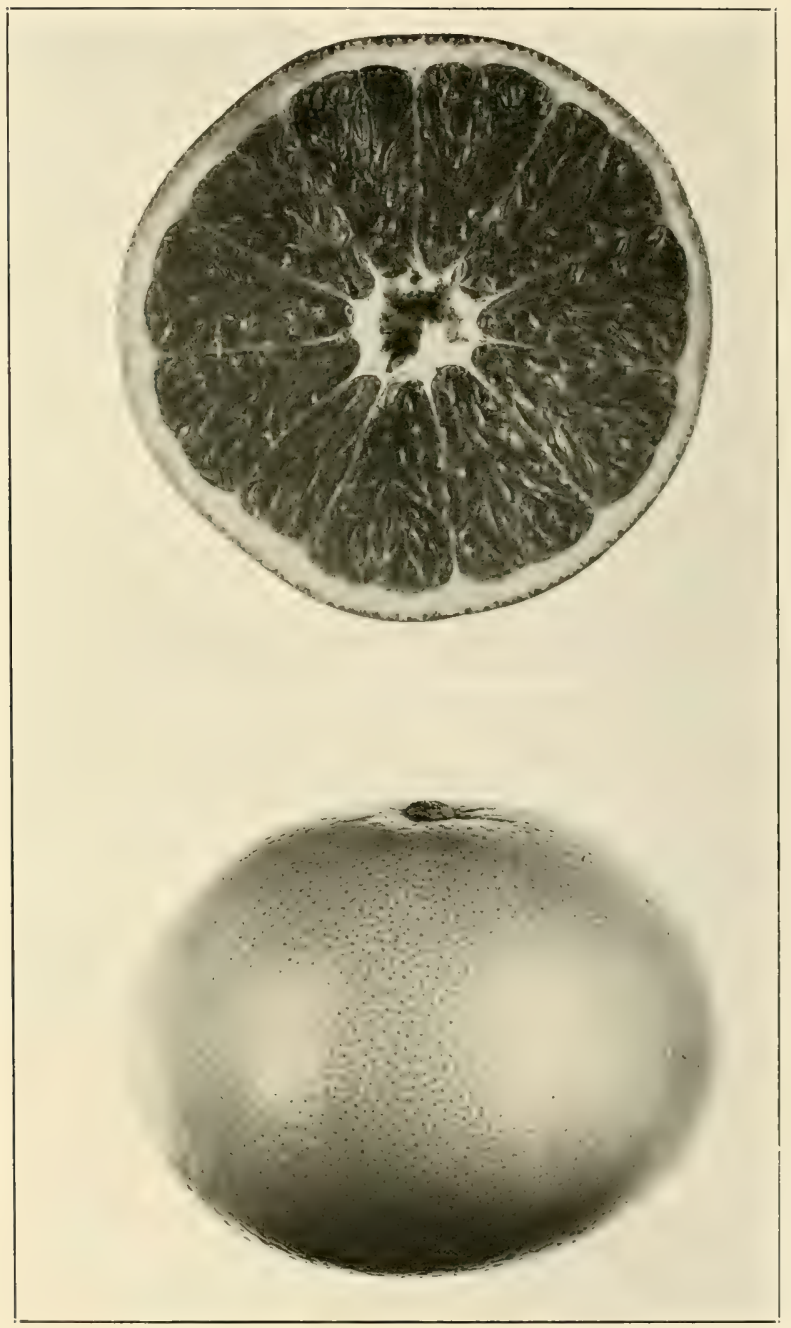

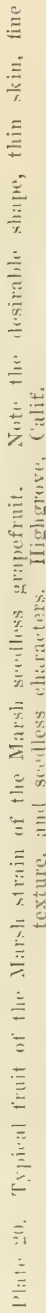




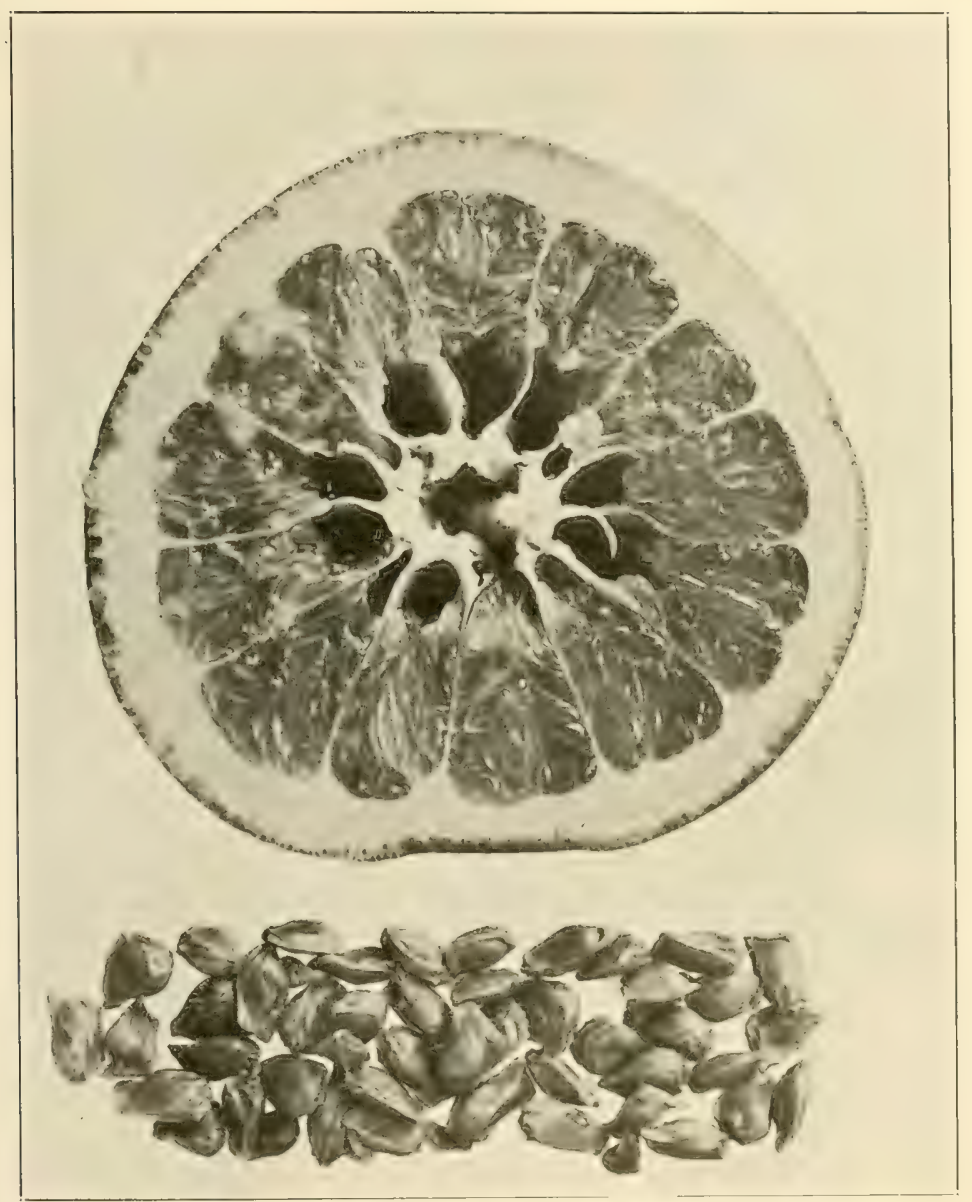

Plate 21. A fruit of the Seedy strain of the Marsh grapefruit. Highgrove, Calit. 


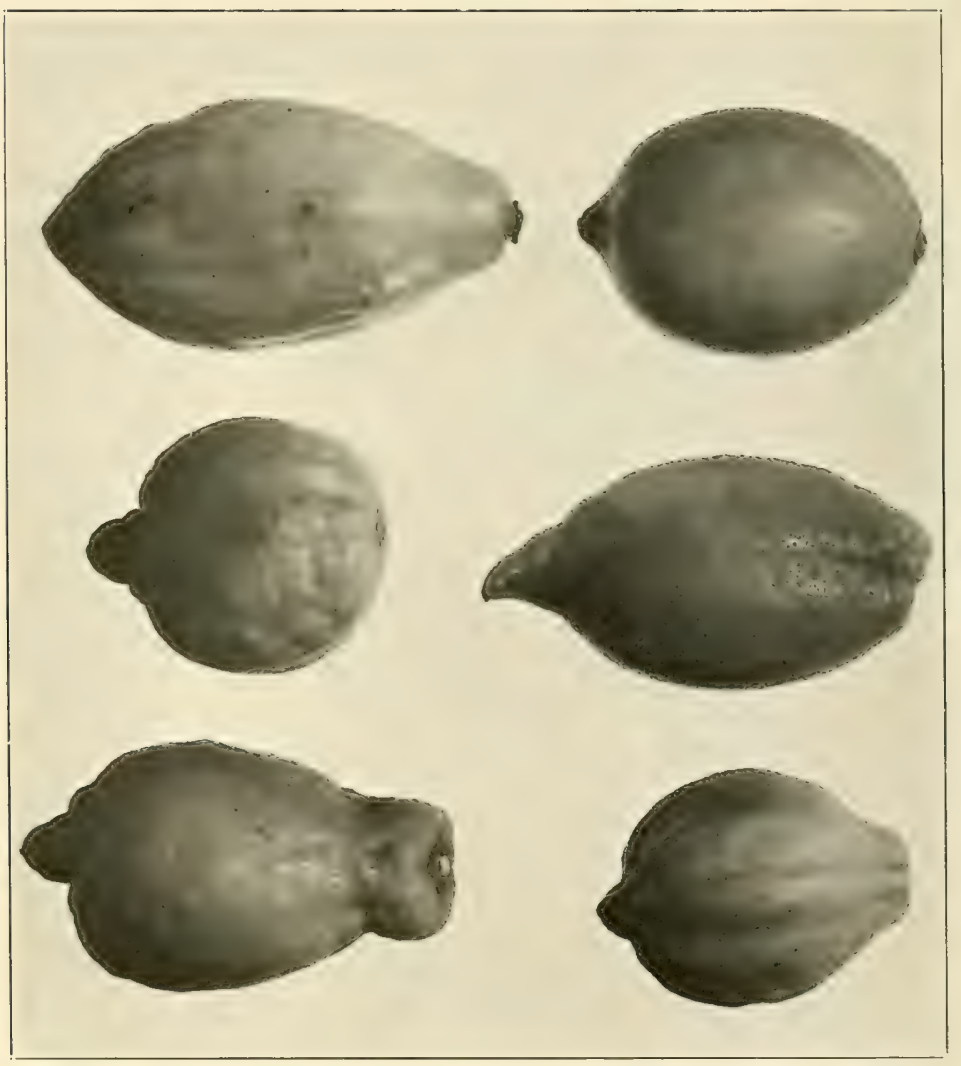

Plate 20. A few of the Eurcka lemon types that frequently oceur as buil variations on a single tree. Corona, Calif. 


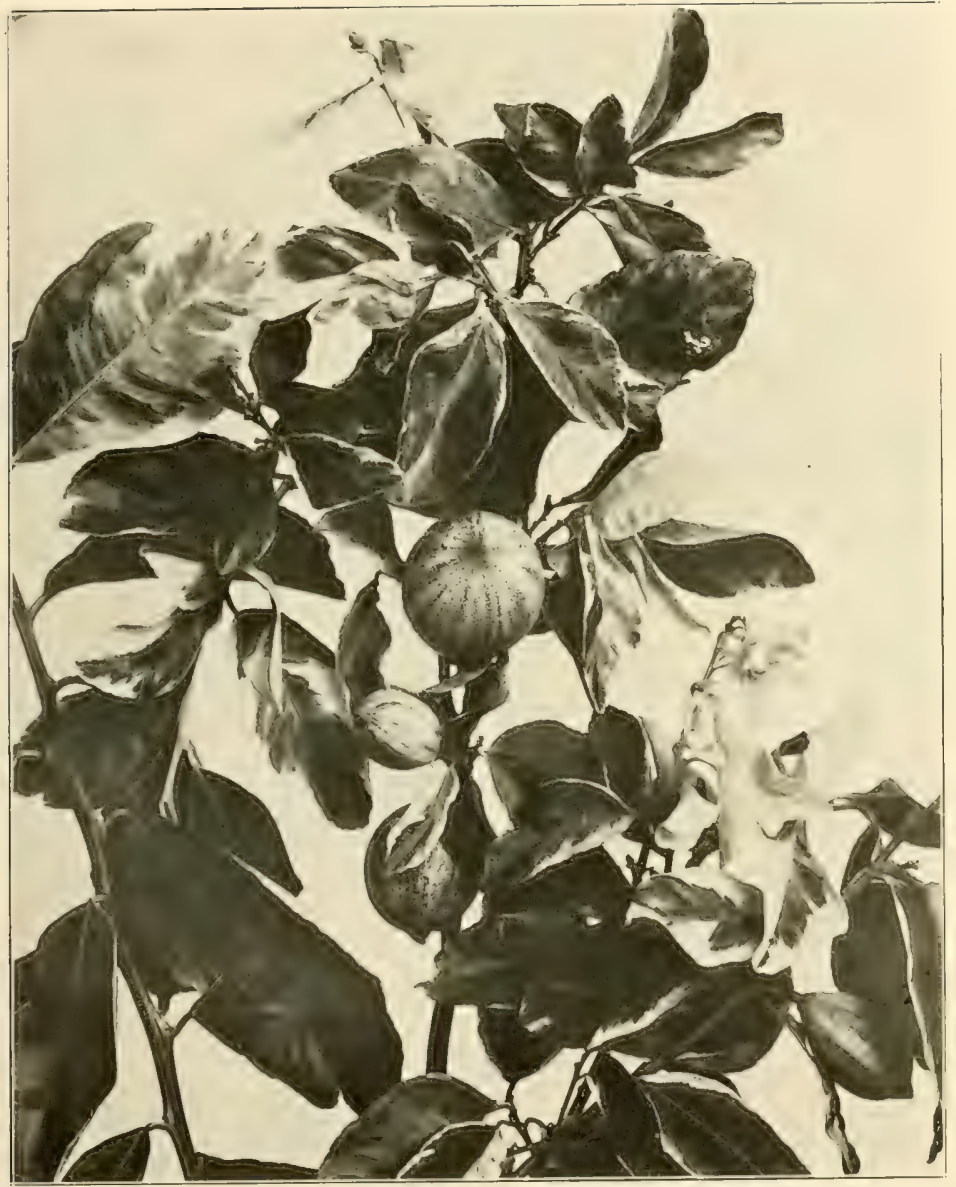

Plate 23. Branches of the Variegated Eureka lemon, showing the characterisiie markings of fruits, leaves, and roung twigs. This strain originated as a branch mutation and has been propagated through three bud generations. Corona, Calif. 


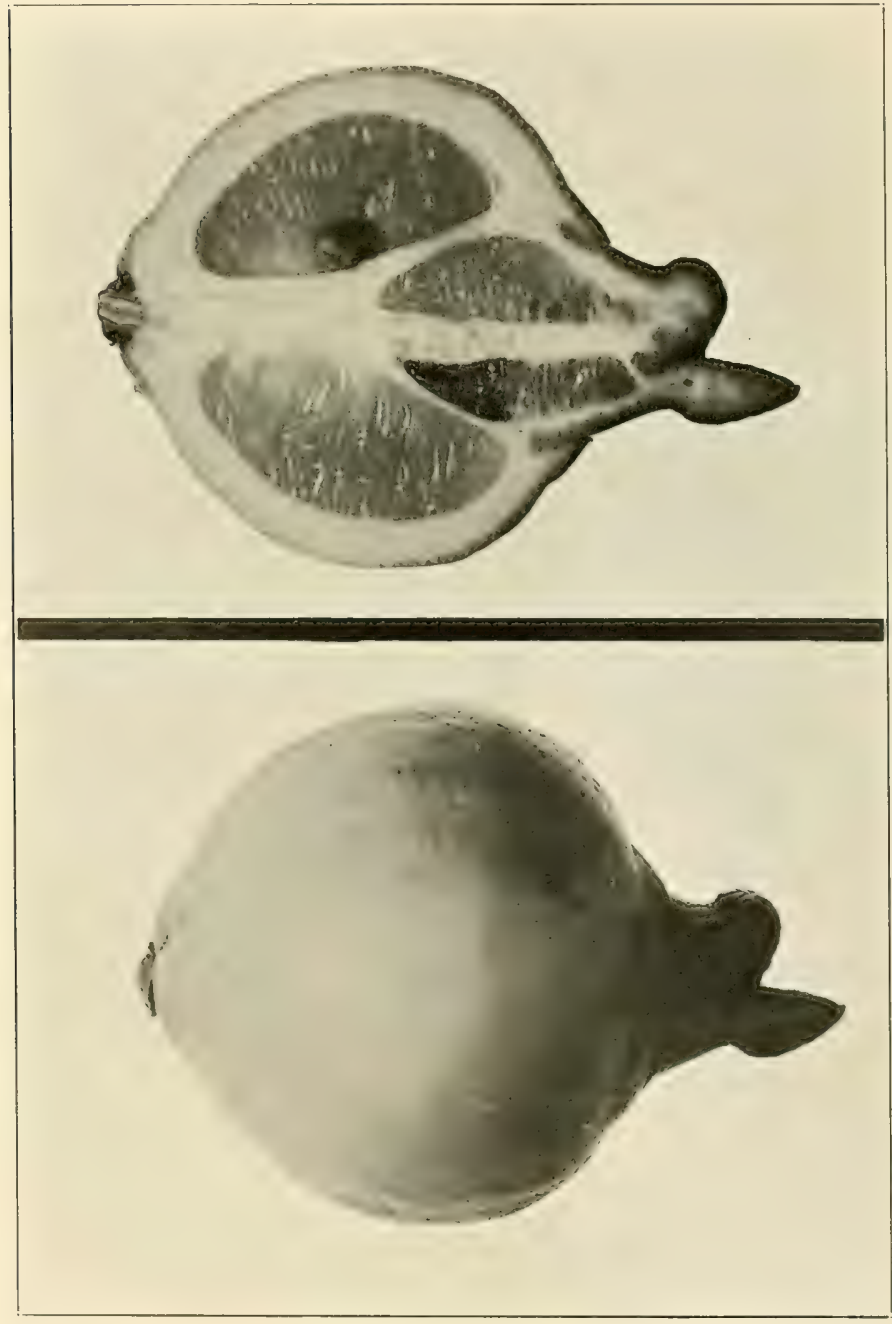

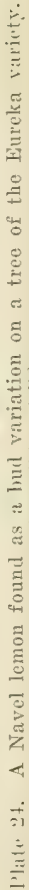




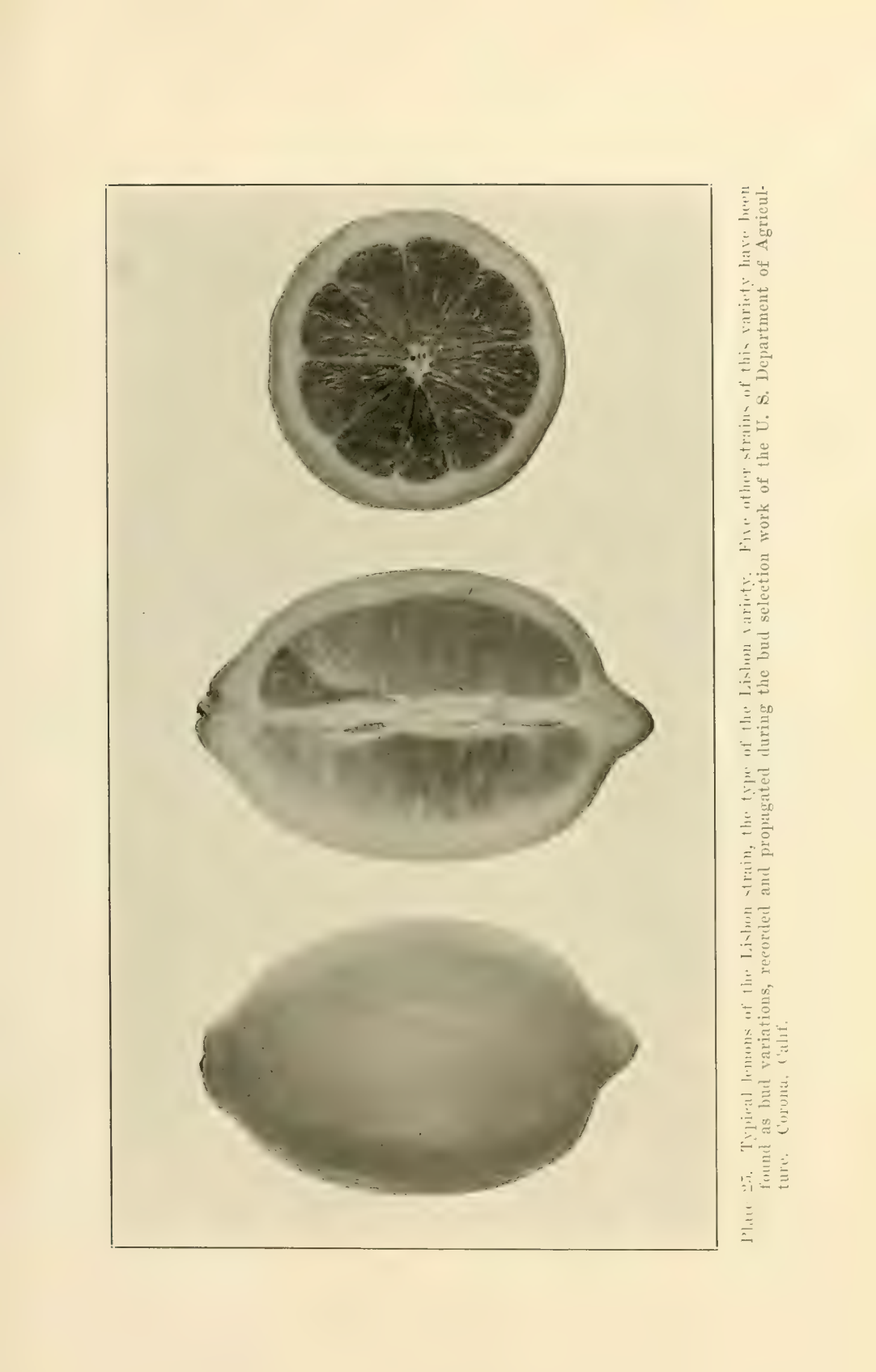




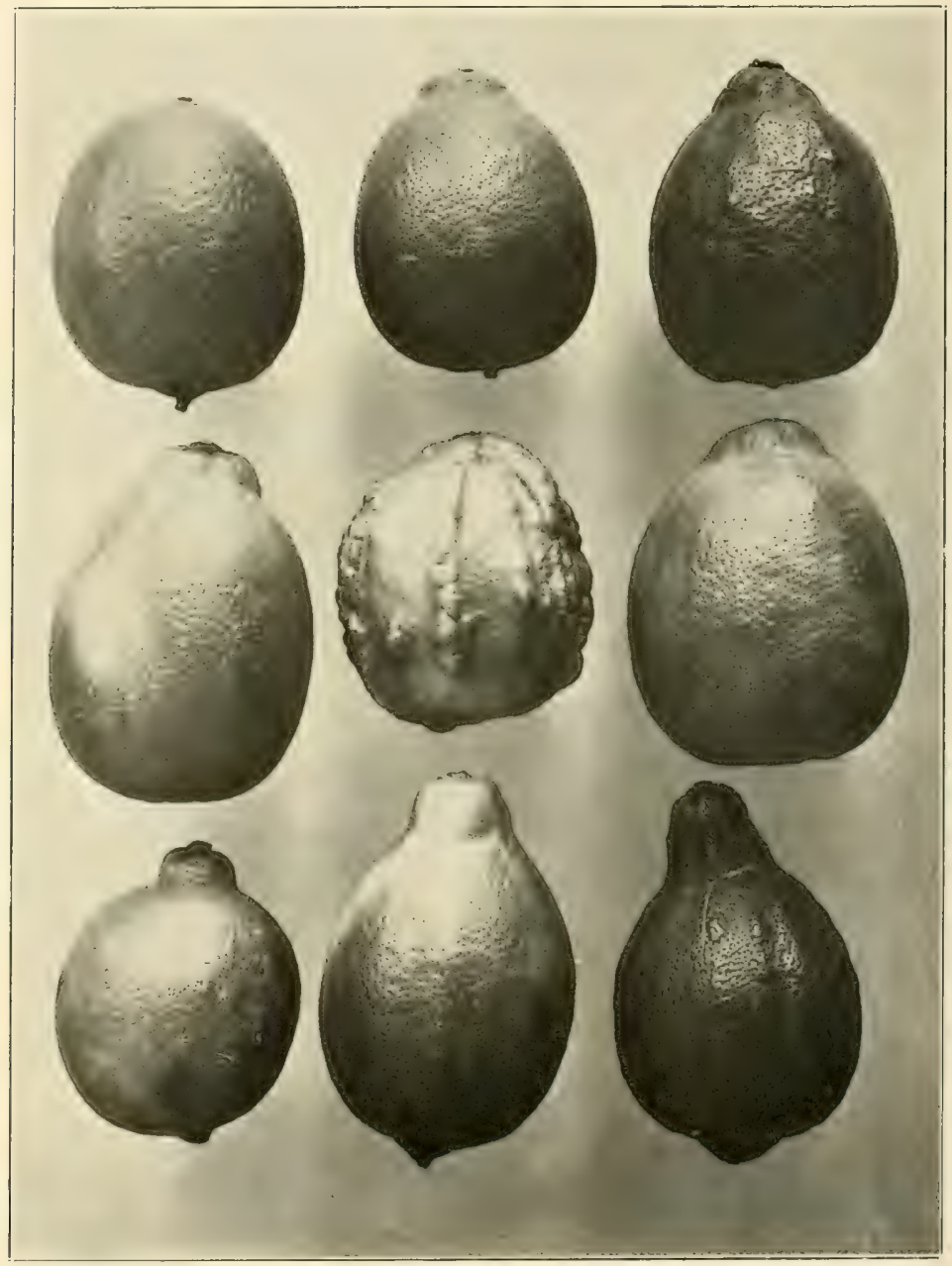

Plate 26 . Lishon lemons, showing pronouncel viriatims oecurring on a single tree of an inferior strain. Coronil, Calif. 


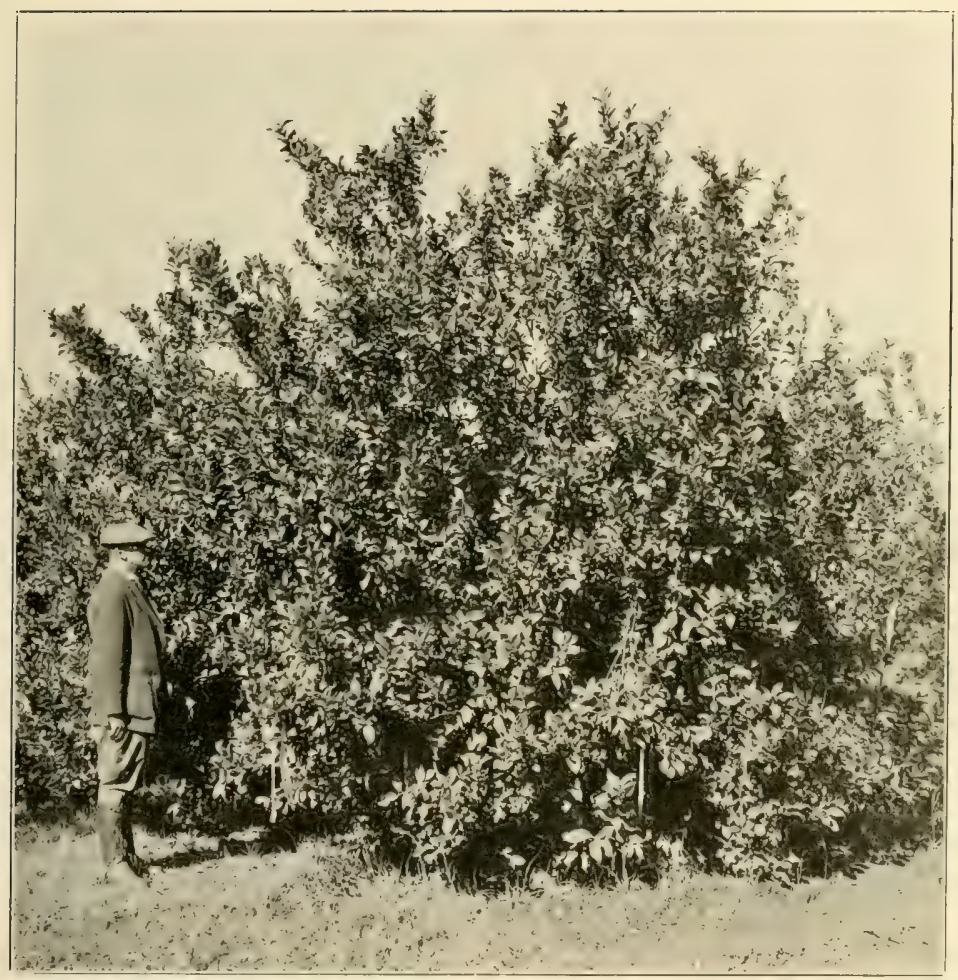

Plate 27. A typical tree of the Shale Tree strain of the Eureka lemon. The trees of this strain are vigorous and rapid in growth but low in proluction, and bear fruits of a low graile. Corona, Calif. 


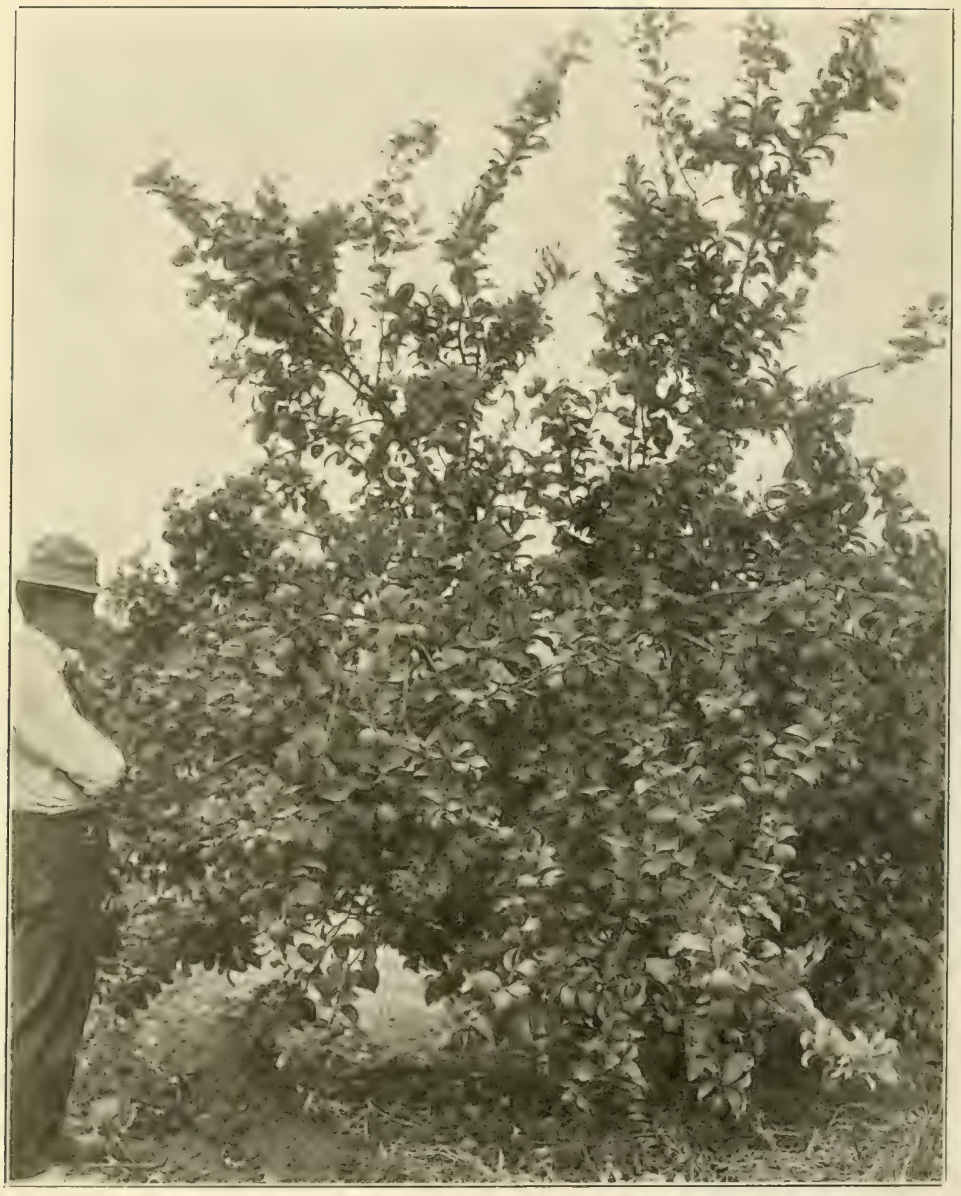

Plate 2s. A young Eureka lemon tree of the Eureka strain. Note the proluctive condition of the tree and the fine type of fruit. Corona, Calif. 


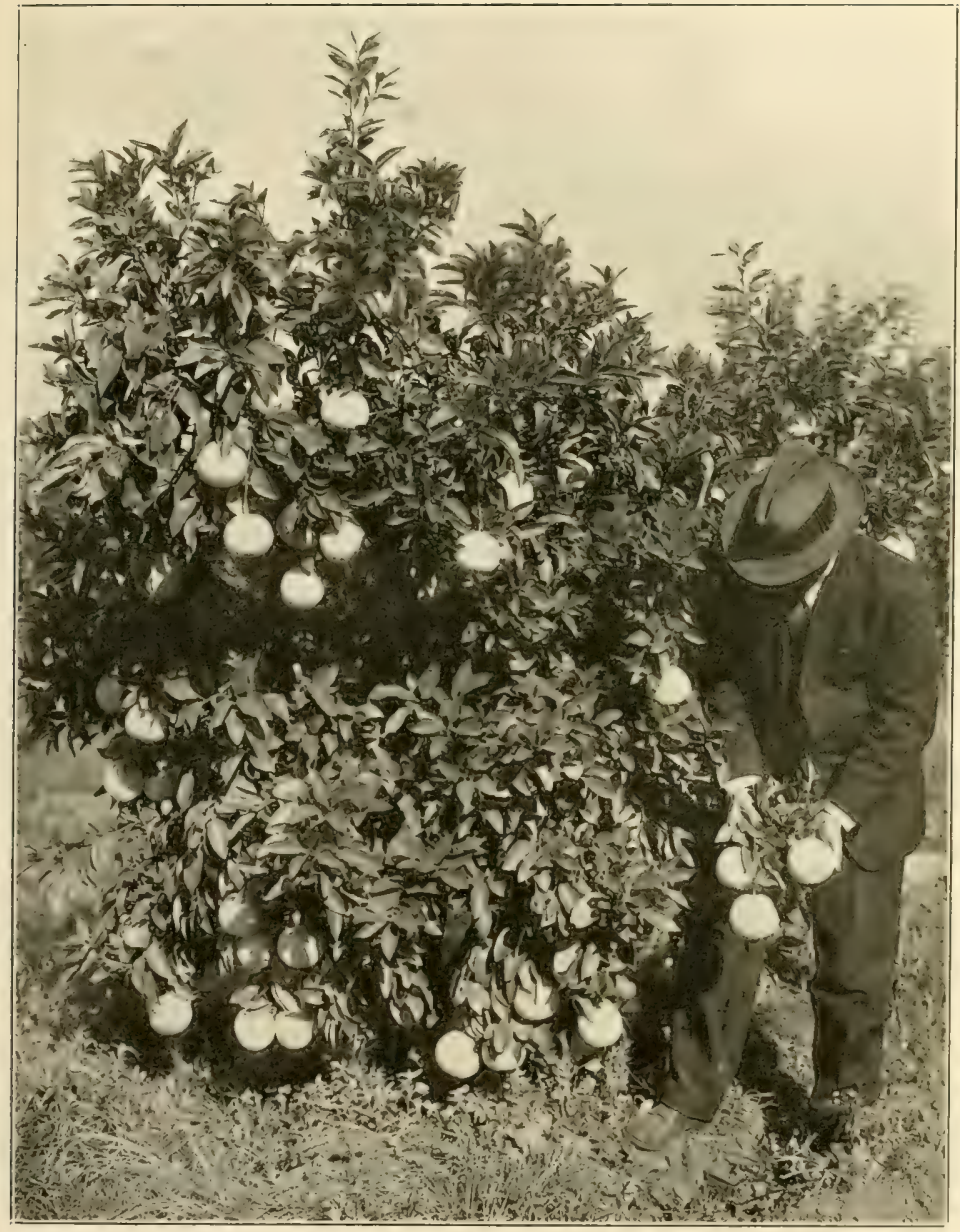

Plate 29. Marsh grapefunit top-worked on an undesirable tree. Highgrove, Calif. 


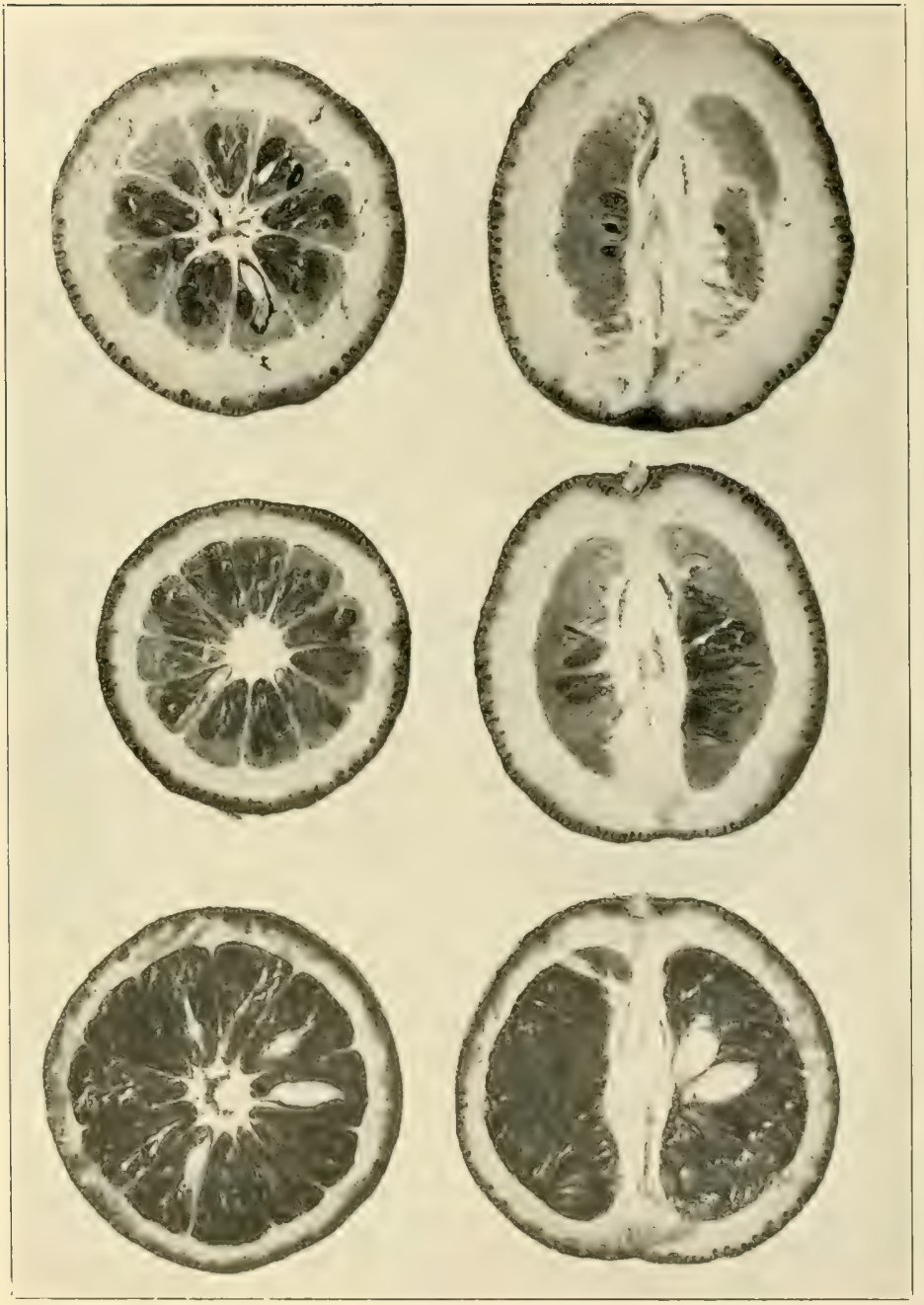

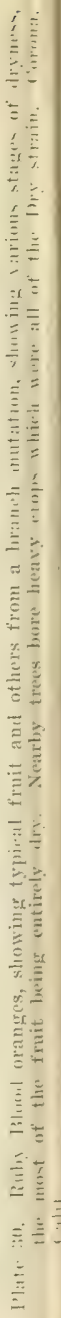




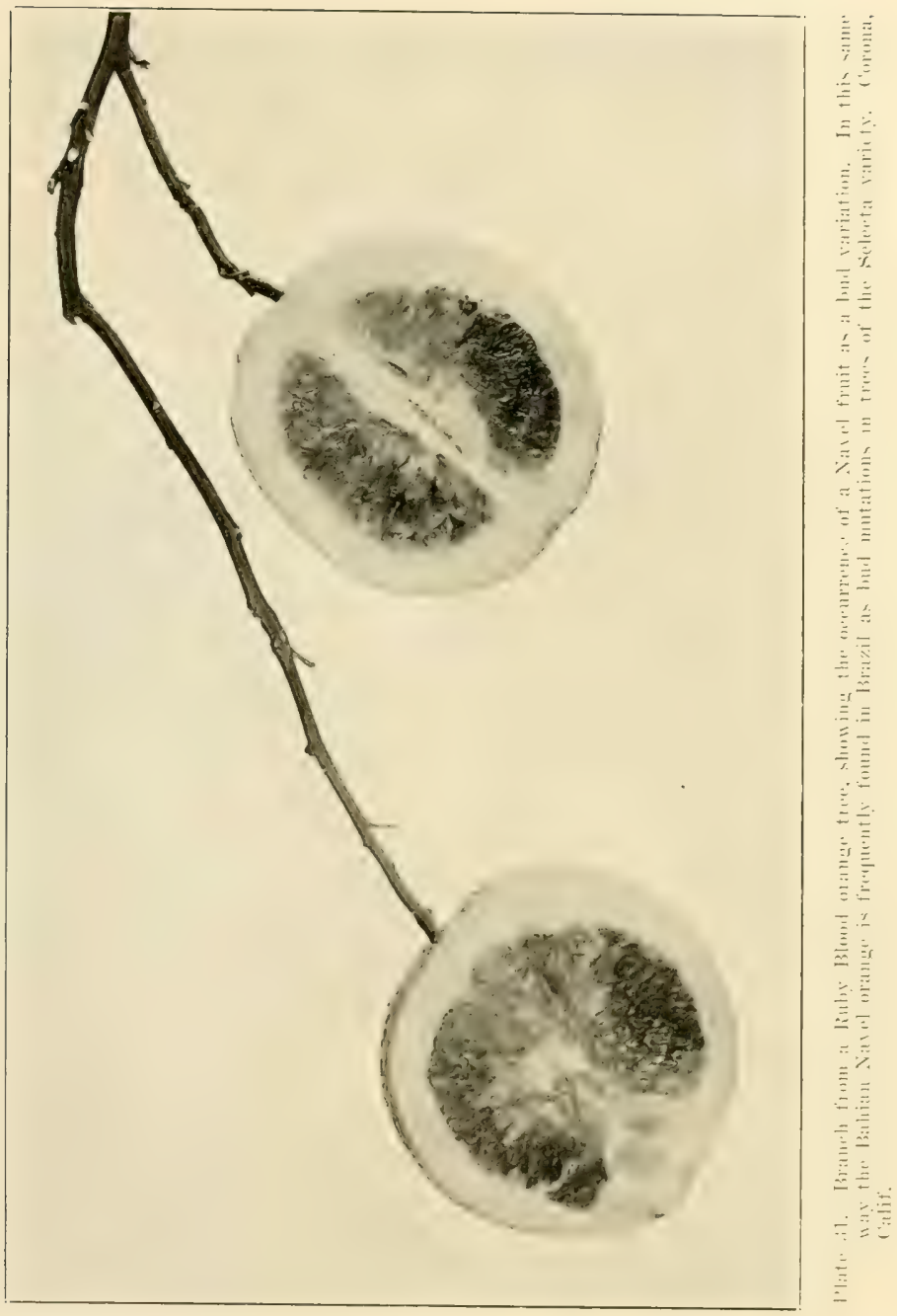




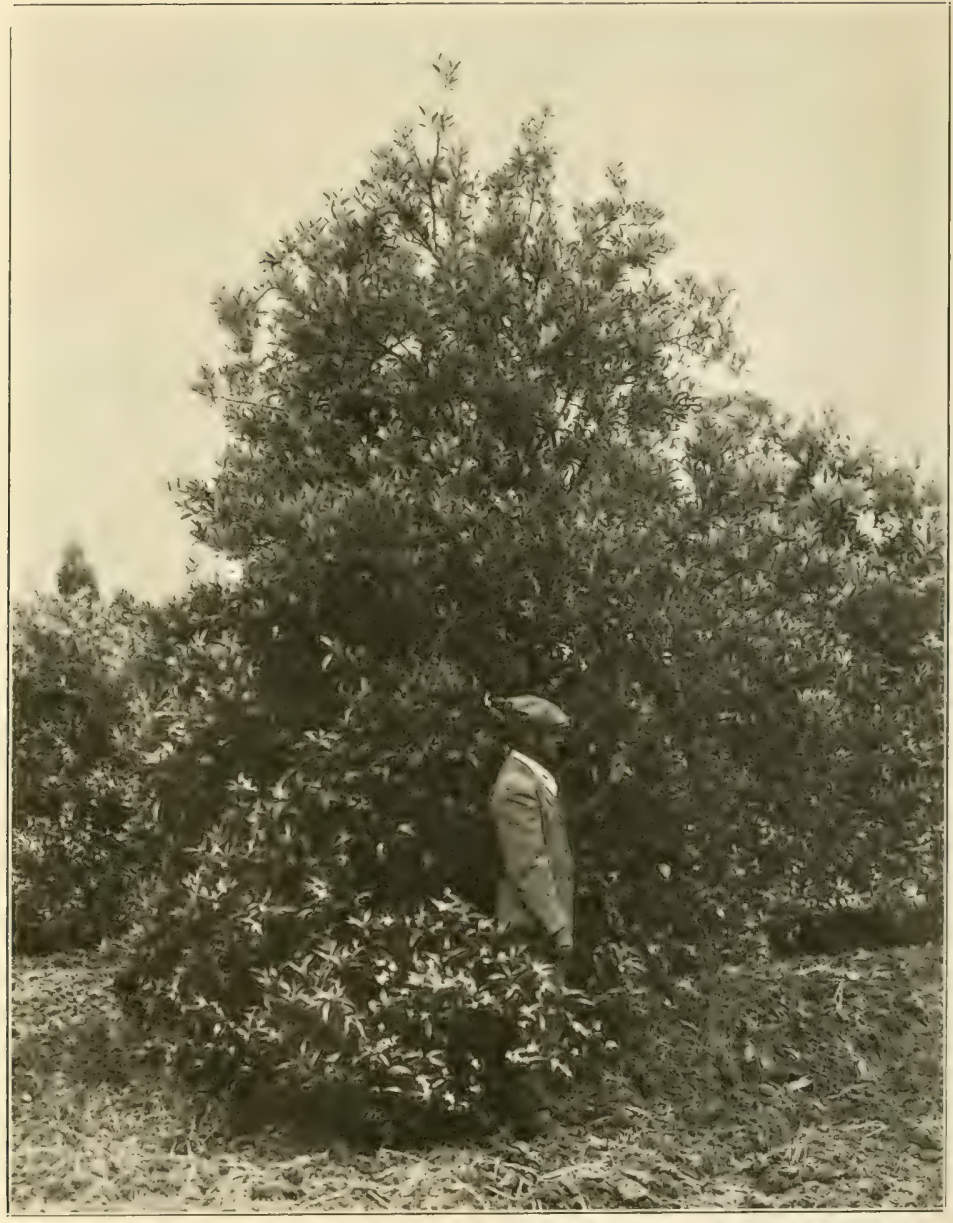

I'late 32. Thomson orange tree in which the entire upper part and right sile are barren every season, the lower left portion bearing normally. Riverside, Calit. 


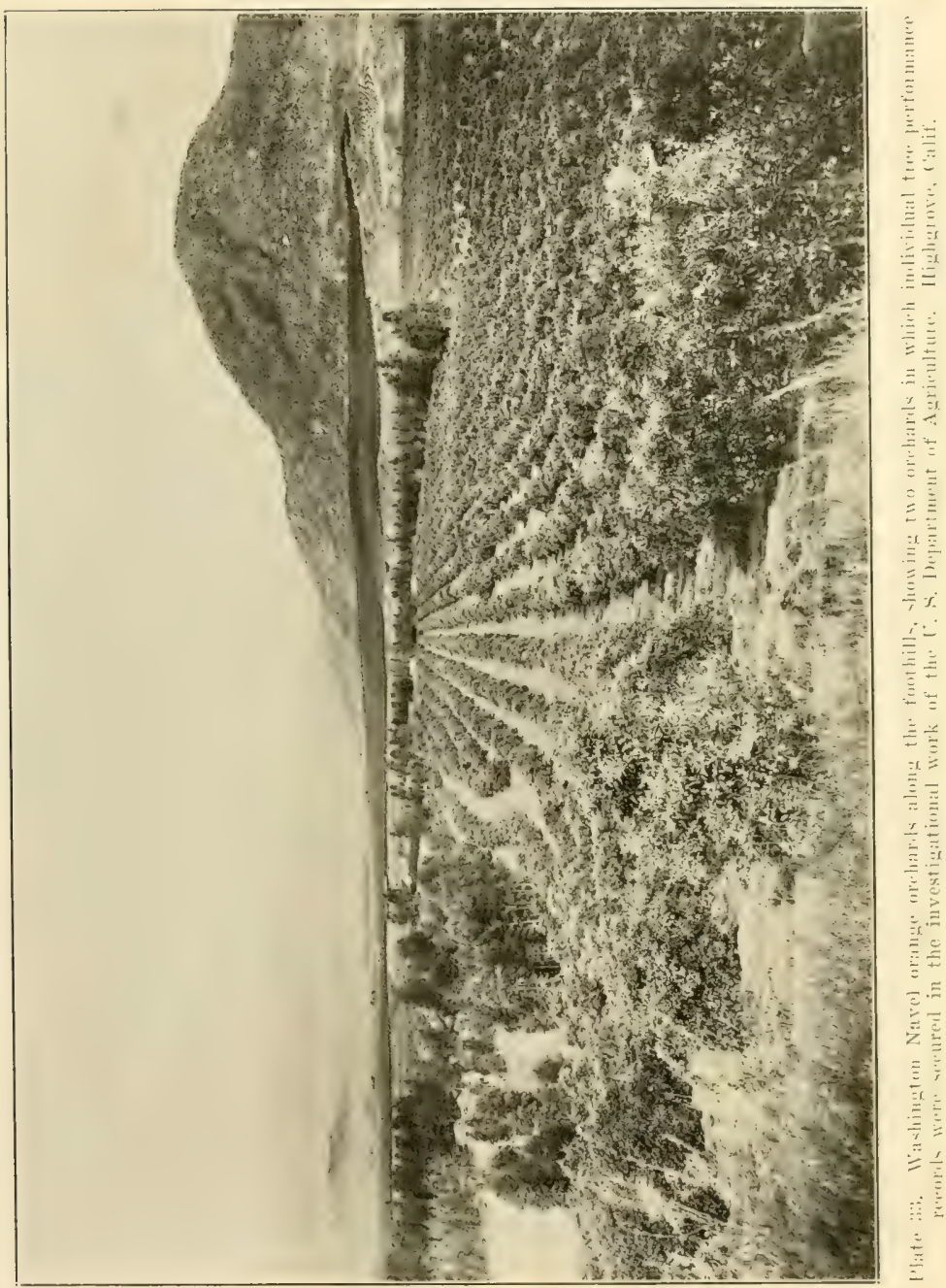




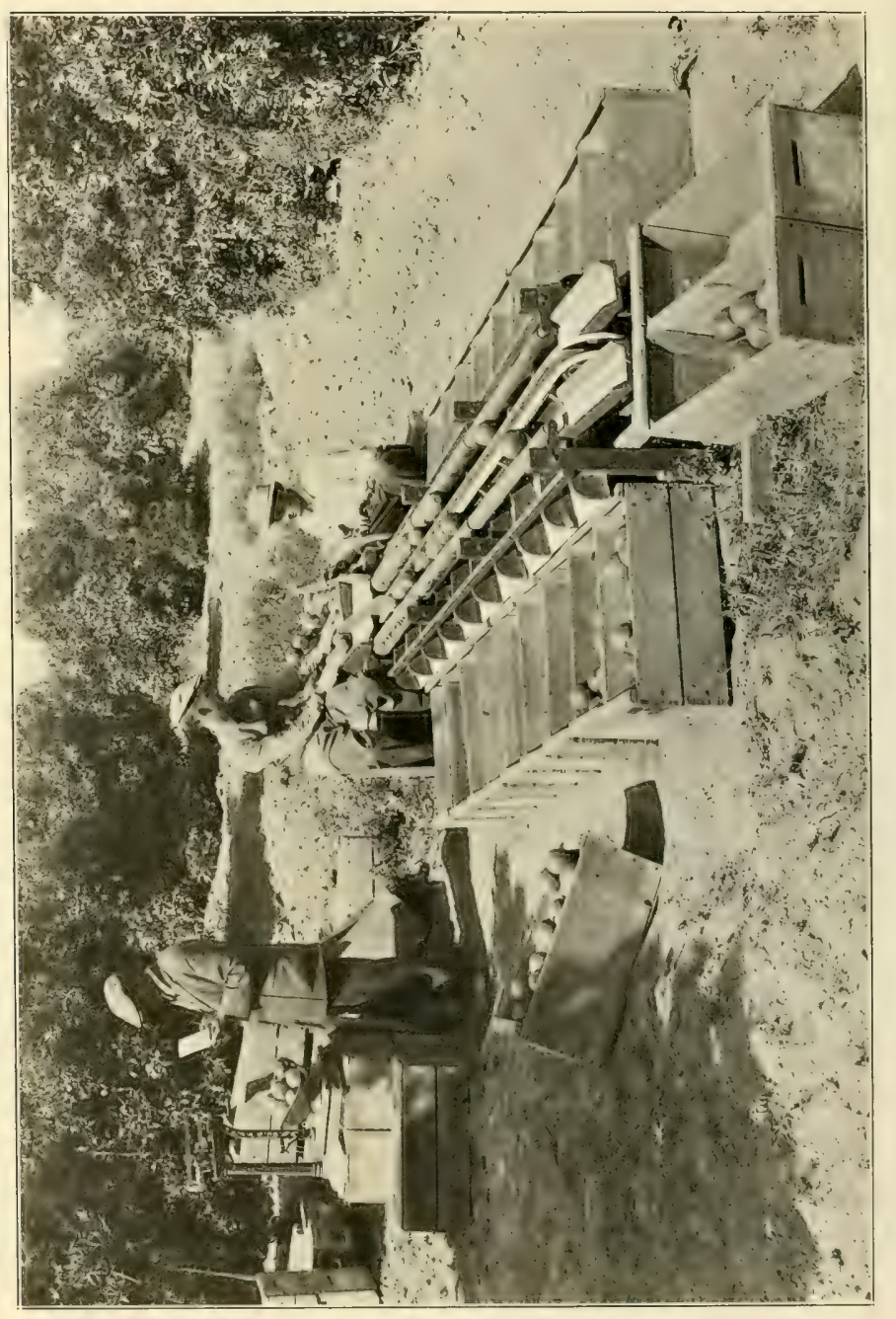

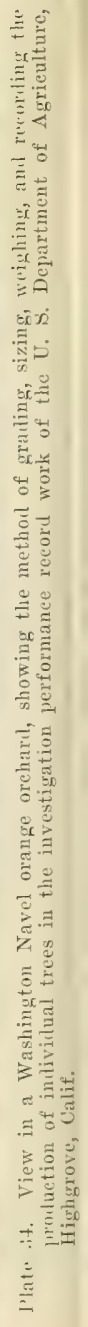




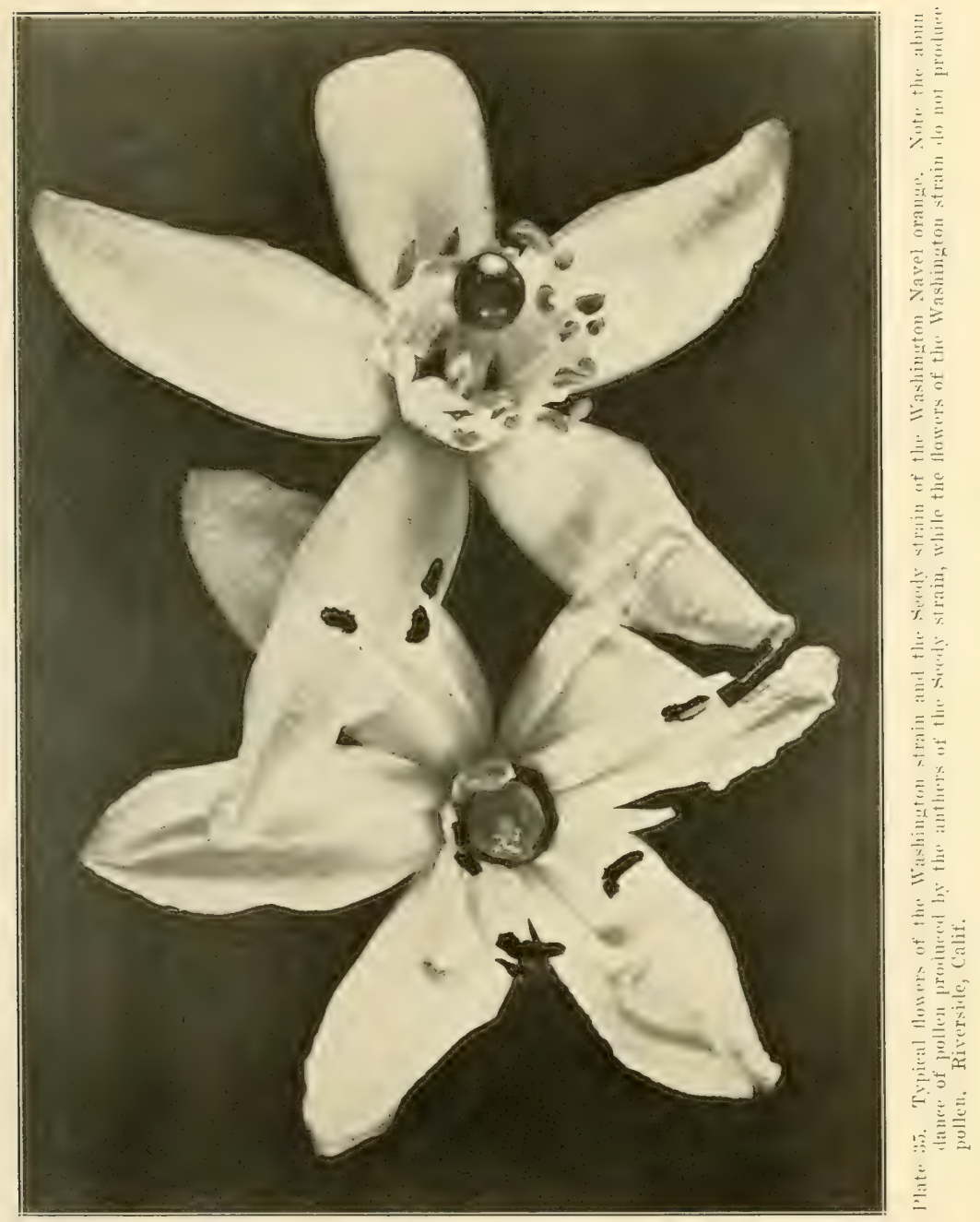




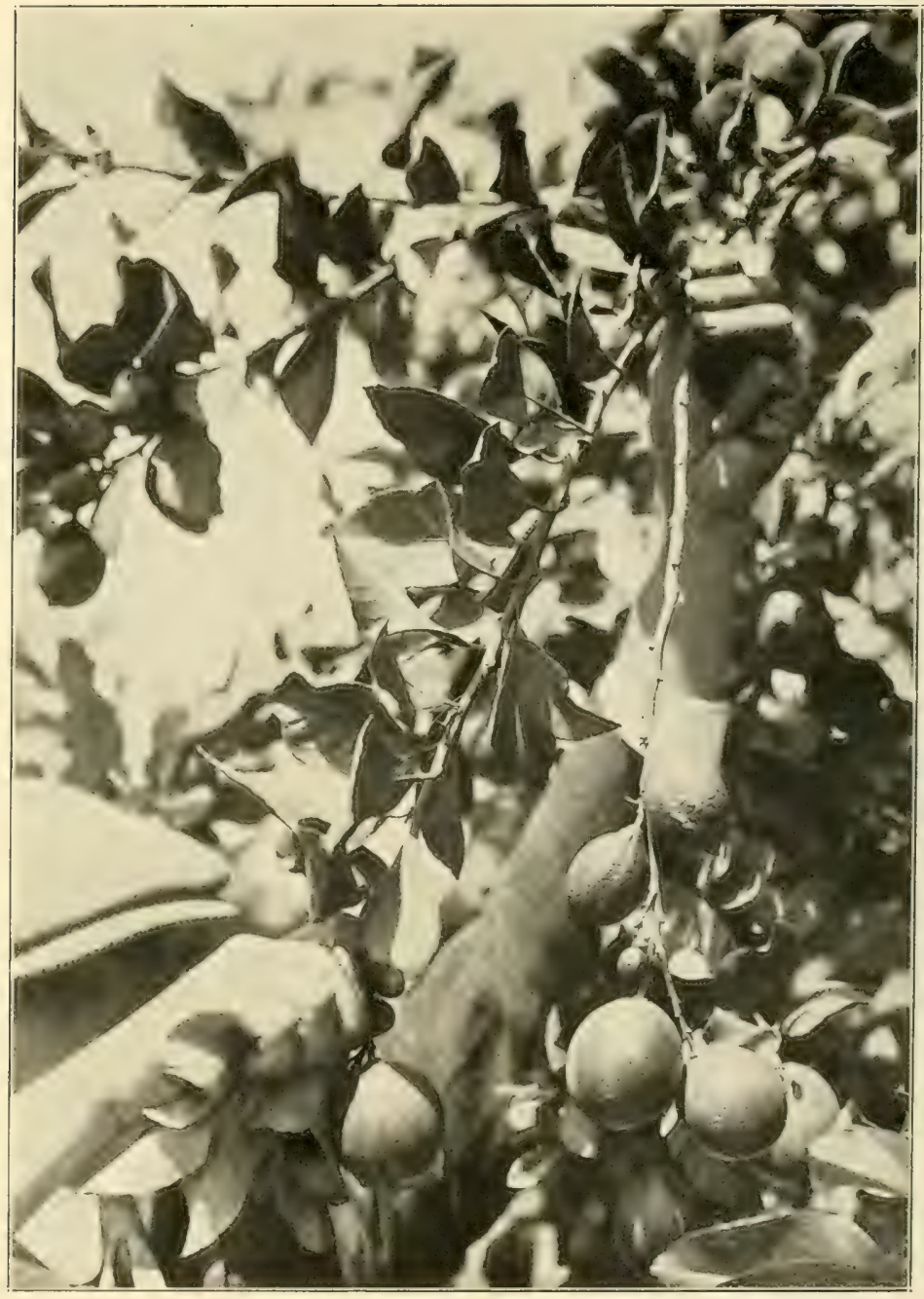

Plate 36. View in an Eureka lemon trce, showing the type of fruit-baring but-mool alvisel for use in propagating from select parent trees. The leares liave been eut from one twig in order to show its character to better advantage. Corona, Calif. 


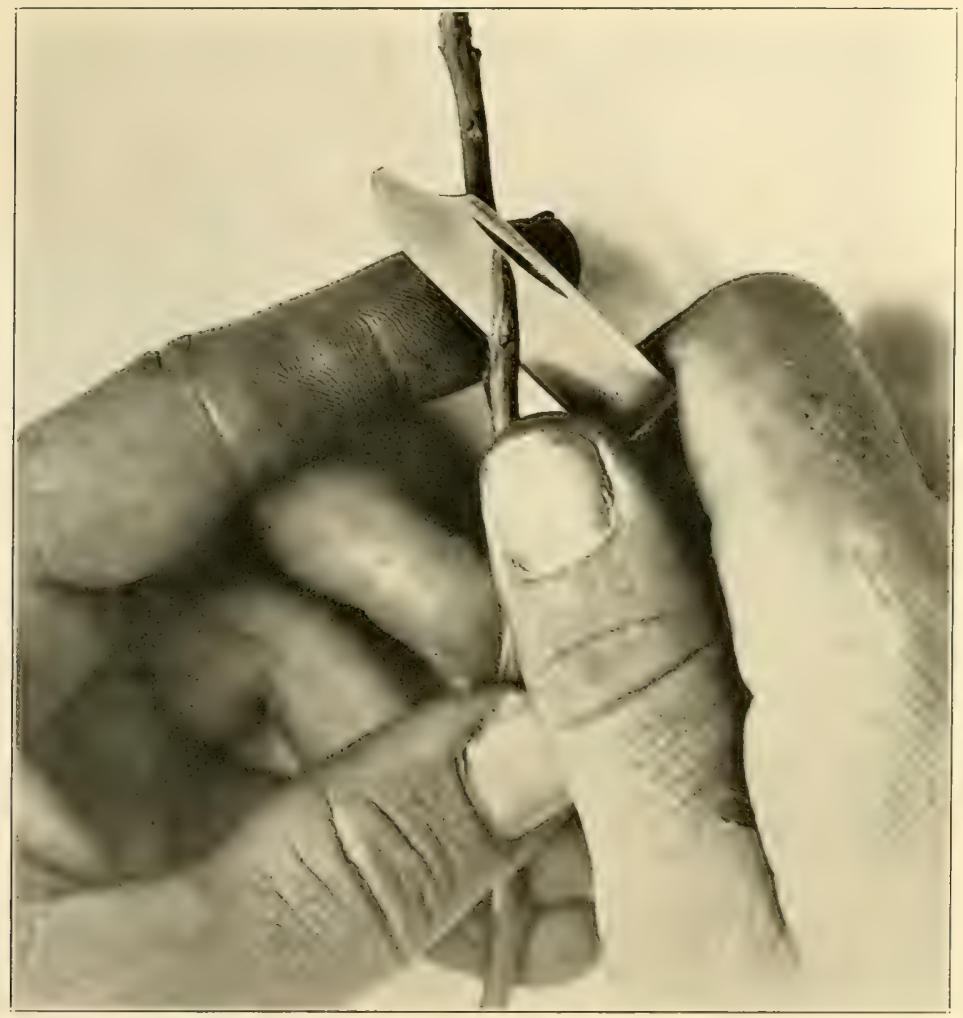

Plate 37. Citrus propagation: Cutting a bud from a typical buc-stick of fruit-bearing wood for insertion into the seedling stock. 


$$
|\|| \mid 1
$$




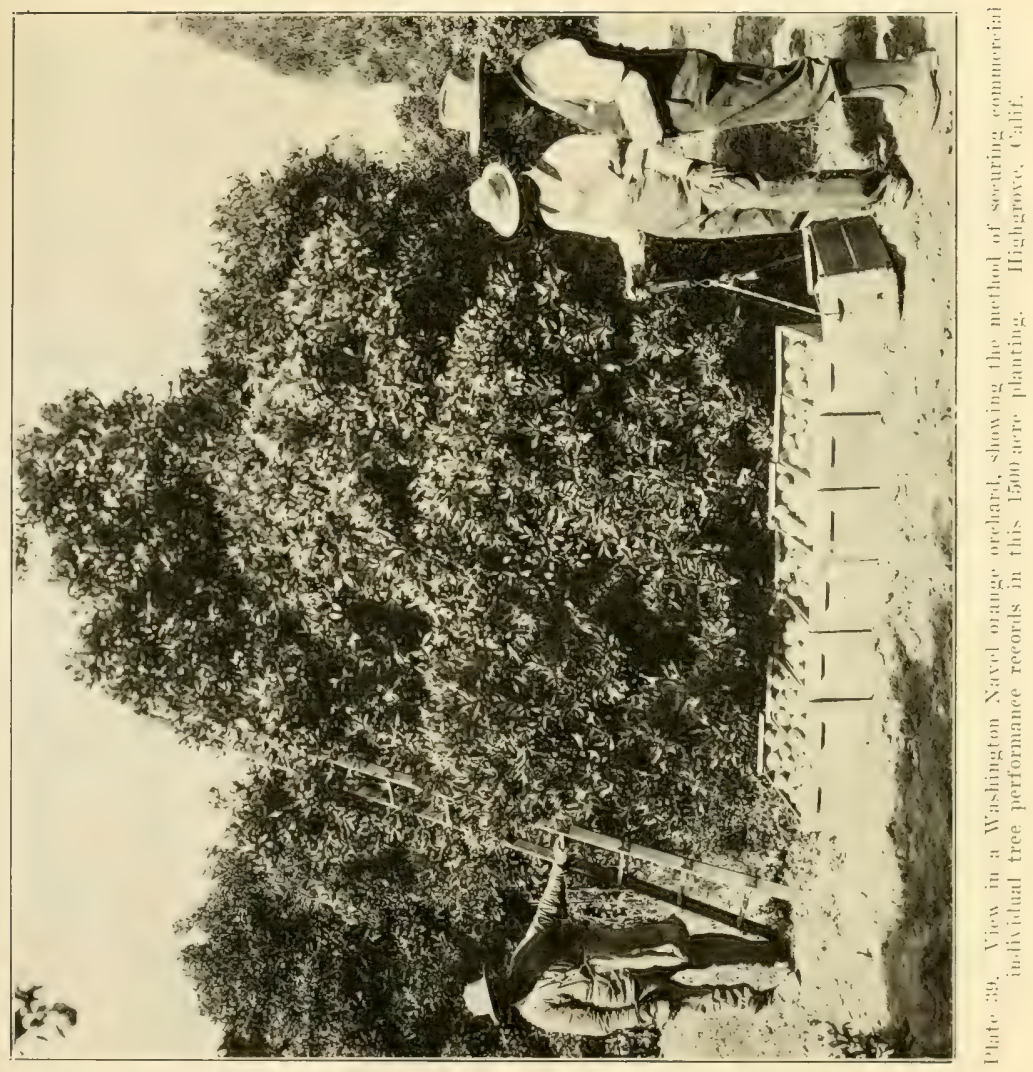




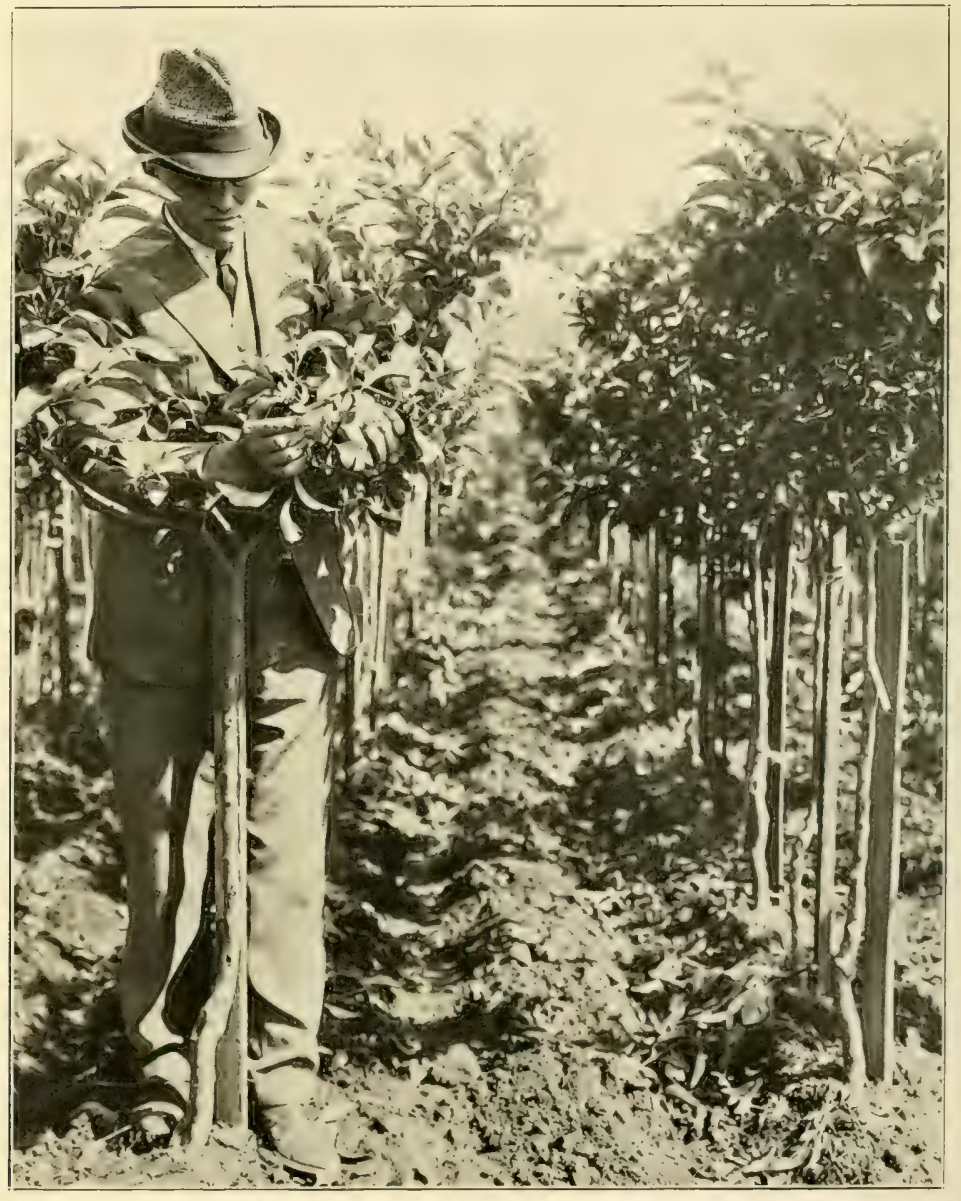

I'late 40. Two-year-old Eureka lemon nursery propagated from selected fruit-bearing buclwood, showing the fine tree development aud the early fruiting tendency. Redlands, Calif. 


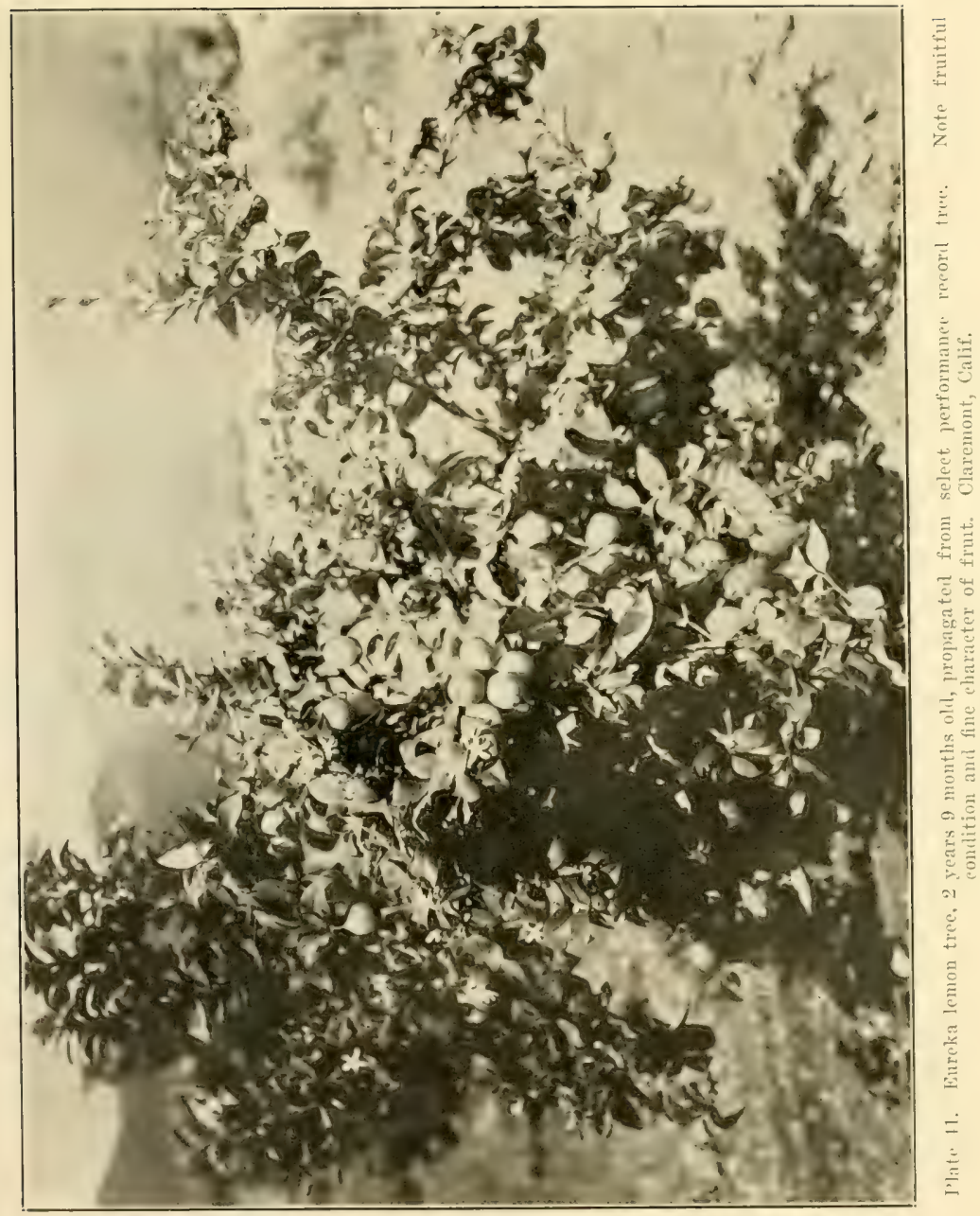








LIBRARY OF CONGRESS

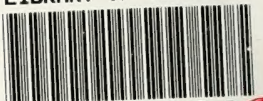

000268083030 